\title{
International Union of Crystallography \\ Tenth General Assembly and International Congress of Crystallography Amsterdam, The Netherlands, 7-15 August 1975
}

Table of Contents

Introduction and Opening Ceremony . . . . . . . . 692

Tenth International Congress . . . . . . . . . . . 692

Minutes of the Tenth General Assembly

Introduction and list of delegates . . . . . . . . .

First Session, 7 August 1975, 5.45 p.m.

(1) Introductory remarks by the President . . . . 693

(2) Procedural matters . . . . . . . . . . . . 693

(3) Approval of Agenda . . . . . . . . . . . . . . . . . . 693

(4) Application for membership of the Union (see also Minute 41) ............. . 693

(5) Approval of Minutes of the Ninth General Assembly .............. . 693

(6) Amendments to Statutes and By-Laws (see also Minutes 28, 30 and 56)

(7) Report of the Executive Committee : . . . . . 693

Second Session, 8 August 1975, 5.30 p.m.

(8) Report of the Executive Committee ....... 694

(9) Financial Report . . . . . . . . . . . 694

(10) Reports of the Commissions . . . . . . . . . 695

(11) Commission on Journals . . . . . . . . . . . . 695

(12) Commission on Structure Reports . . . . . . . 695

(13) Commission on International Tables . . . . . . 695

(14) Working Party on Information Services . . . . 695

(15) Commission on Crystal Growth . . . . . . . . 696

(16) Commission on Crystallographic Apparatus . . . 696

(17) Commission on Crystallographic Computing . . 696

(18) Commission on Crystallographic Data . . . . . 696

(19) Commission on Crystallographic Nomenclature : 696

(20) Commission on Crystallographic Studies at Controlled Pressures and Temperatures . . . . 696

(21) Commission on Crystallographic Teaching . . . 696

(22) Commission on Electron Diffraction . . . . . . 696

(23) Commission on Neutron Diffraction . . . . . . 696

(24) Ad interim Commission on Charge, Spin and Momentum Densities .........

(25) Review of the activities of the Commissions of the Union . . . . . . . . . . . .

(26) Consideration of the need for a commission on Charge, Spin and Momentum Densities . . . .

(27) Size of Commissions . . . . . . . . . . . . . 697

Third Session, 12 August 1975, 5.30 p.m.

(28) Amendments to the By-Laws.

(29) Confirmation of the appointment of the Editors of the publications of the Union . . . . . . .

(30) Election of Chairmen and members of Commissions

(31) Election of Representatives on bodies not belonging to the Union . . . . . . . . . . . .

(32) Reports from Representatives on bodies not

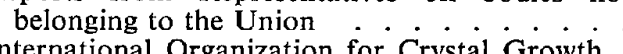

(33) International Organization for Crystal Growth

(34) ICSU Abstracting Board .

(35) ICSU Committee on Space Research. Organizing Committee concerned with problems of Physics and Chemistry in Space ......... 699
(36) IUCr-IMA Joint Committee on Nomenclature . 699

(37) Sub-committee on the Union Calendar . . . . . 699

(38) Discussion of the future policy of the Union . . 699

(39) Budget estimates for the period until the Eleventh General Assembly ... .

(40) Unit contribution for the period until the Eleventh General Assembly . . . . . . . . . 700

Fourth Session, 15 August 1975, 2.15 p.m.

(41) Application for membership of the Union . . 700

(42) Election of Officers of the Union ...... 700

(43) Election of the Chairman of the Commission on Crystallographic Apparatus . . . . . . 701

(44) Date and place of the Eleventh General Assembly 701

(45) Free circulation of scientists . . . . . . . 701

(46) Reports of the Commissions, continued. . . . 702

(47) Commission on Journals . . . . . . . . . . 702

(48) Commission on International Tables . . . . . . 702

(49) Commission on Charge, Spin and Momentum Densities ............. 702

(50) Commission on Crystallographic Apparatus . . 702

(51) Commission on Crystallographic Data . . . . . 702

(52) Commission on Crystallographic Teaching . . . 702

(53) Fifth Edition of the World Directory of Crystallographers.......... 702

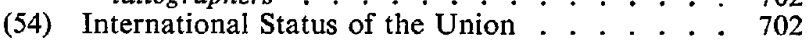

(55) Establishment of a President's Fund . . . . . . . . . 702

(56) Sub-committee on Statutes and By-Laws . . . . 703

(57) Programme Committee for the Eleventh International Congress of Crystallography. . . . . . 703

Closing Ceremony, 15 August 1975, 4.00 p.m.

Exhibition of photographs and drawings . . . . 703

Votes of thanks......... 703

Annex I: Appendices to the Agenda of the Tenth

696 (A) Report of the Executive Committee. . . . . . . . . . 7047

696 (B) Financial report ........... 706

(C) Reports of the Commissions of the Union . . . . 712

(D) Report of the Working Party on Information Services. . . . . . . . . . . . . 720

(E) Review of the activities of the Commissions of the

(F) Reports of the Representatives on bodies not belonging to the Union ...........

(G) Report of the IUCr-IMA Joint Committee on Nomenclature . . . . . . . . . . . . .

(H) Summary of the activities of the Sub-committee on the Union Calendar . . . . . . . . . .

(I) Budget estimates for the period until the Eleventh General Assembly; determination of the unit

Annex II: Statutes and By-Laws of the Union . . .

Annex III: Memberships of Committees and Commissions, and Representatives on other bodies

Annex IV: Adhering Bodies and National Committees for Crystallography . . . . . . . . 


\section{Introduction and Opening Ceremony}

By invitation of the Stichting voor Fundamenteel Onderzoek der Materie met Röntgen- en Elektronenstralen (FOMRE), the Tenth General Assembly and International Congress of Crystallography were held at the International Congress Centre RAI, Amsterdam, The Netherlands, 7-15 August 1975.

The meetings were attended by 1490 scientists of whom 144 were from the Netherlands and the remainder from the following 42 countries: Argentina, Austria, Australia, Belgium, Bulgaria, Brazil, B.R.D., Canada, Cuba, Czechoslovakia, D.D.R., Denmark, Finland, France, Greece, Hungary, Hong Kong, India, Iran, Iraq, Italy, Israel, Japan, Malaysia, Mexico, New Zealand, Norway, Pakistan, Poland, Puerto Rico, Rumania, South Africa, Spain, Sweden, Switzerland, Thailand, Tunesia, U.K., U.S.A., USSR, Venezuela and Yugoslavia.

The General Assembly and Congress were opened formally on the afternoon of 7 August. The opening ceremony commenced with a speech of welcome by the Chairman of the Organizing Committee and the Netherlands National Committee for Crystallography, Professor D. FeIL. Professor G. D. RIECK then introduced the President of the Koninklijke Nederlandsche Academie voor Wetenschappen, Professor H. B. G. CASIMIR, who opened the General Assembly and Congress, and Professor Dorothy HodgkIN, President of the IUCr, who replied on behalf of the Union. After a musical interlude by the Amsterdam Police Brass Band, Professor CARoline $\mathrm{H}$. MacGillavry presented the Congress Discourse, entitled Order and Beauty.

There then followed a film entitled Sky over Holland, and a get-together party before the General Assembly commenced its business.

\section{Tenth International Congress}

\section{Scientific programme}

The scientific programme included (i) the Congress Discourse by C. H. MacGillavry mentioned above, (ii) six General Lectures; Crystallography and genetics (the molecular structure of transfer RNA) by A. RICH, The study of crystal structures by transmission electron microscopy by J. M. Cowley, Relations between crystal structures and physical properties of solids by F. JELLINEK, Interactions in molecular and non-molecular crystals, crystal packing and lattice dynamics by A. I. KITAIGorodskiI, Perfect and nonperfect crystals by A. AUTHIER and Crystal structure and chemical reactivity by J. D. DuNITz, (iii) a special General Session at which P. P. Ewald gave a lecture on The early history of the International Union of Crystallography and there was a discussion to which many present at the early meetings of the Union contributed, (iv) approximately 360 papers presented as oral contributions and approximately 560 papers presented at poster sessions, and $(v)$ the book of Collected Abstracts. Included in this scientific programme were 15 Open Commission Meetings, which were organized by the Commissions of the Union.

According to the arrangements made by the Programme Committee, and approved by the Executive Committee, each participant was allowed to submit only one abstract, with the exception that an additional abstract on crystallographic teaching could be submitted. The organizing Chairmen for each topic were responsible for determining whether a paper should be presented at a poster session or at an oral presentation and, in the case of oral presentations, the time allocated to the speaker. The Chairmen also selected speakers to present invited papers at the oral sessions. The work of the Chairmen was carried out according to genera! guidelines given by the Programme Committee in consultation with the Executive Committee. The abstracts submitted were printed, by direct reproduction of the typescript copy, in the book of Collected Abstracts and in a Supplement to Acta Crystallographica, Section A. A copy of the Supplement was sent to all subscribers to Acta Crystallographica and the Journal of Applied Crystallography.

\section{Exhibitions}

A commercial exhibition of crystallographic equipment and scientific books was held in the West Hall of the Congress Centre, which was also the location used for the poster sessions and an exhibition of models of protein structures. Exhibitions of non-commercial equipment and of photographs and drawings, and a display of Union publications were also organized.

\section{Social arrangements}

All Congress participants were invited to attend a concert and party given by N. V. Philips' Gloeilampenfabrieken in the Concertgebouw, and a reception given by the Netherlands Government and the Municipality of Amsterdam in the Rijksmuseum. A farewell party and several all-day and half-day excursions were also arranged. An extensive programme of excursions was also provided for those accompanying the Congress participants.

\section{Minutes of the Tenth General Assembly}

These Minutes have been prepared by J. N. King, Executive Secretary, under the authority of S. E. Rasmussen, General Secretary of the Union and Secretary of the General Assembly.

\section{Introduction and list of delegates}

Sessions of the General Assembly were held on the afternoon of Thursday 7 August, the evenings of Friday 8 August and Tuesday 12 August, and the afternoon of Friday 15 August, in the main hall of the International Congress Centre RAI. The following list shows the names of the official delegates appointed by the Adhering Bodies and of the alternates who substituted at one or more sessions. The names are listed by the countries to which the respective Adhering Bodies belong, and the number of votes of the Adhering Body is given in parentheses after the name of each country. The names of the Chairmen of the delegations are printed in bold type; those of alternates are marked by an asterisk. The names of officially appointed delegates who were not present at any session of the Assembly are not included.

Australia (3): H. C. Freeman, E. N. Maslen, T. M. Sabine. Austria (1): A. Preisinger.

Brazil (1): S. Caticha-Ellis* (present only on 15 August),

R. Rodrigues da Silva (absent on 12 and 15 August).

B.R.D. (4): U. Bonse (absent on 15 August), Th. Hahn,

F. Liebau, K. Molière* (present on 15 August only).

H. Wondratschek.

Canada (3): L. D. Calvert, J. Trotter. 
Czechoslovakia (1): M. Dunaj-Jurco (absent on 8 August). D.D.R. (2): H. Peibst, M. Schenk.

Denmark (1): K. Drenck.

Finland (1): K. Kurki-Suonio.

France (4): A. Authier, E. F. Bertaut, P. Herpin (absent on 15 August) M. Hospital* (present only on 15 August), J. Lajzerowicz*.

Hungary (1): K. Sasvári.

India (1): S. Ramaseshan.

Israel (1): W. Traub (replaced by U. Shmueli* for part of the session on 15 August).

Italy (3): M. Mammi, G. Rigault (replaced by A. Coda* for part of the session on 12 August), A. Vaciago.

Japan (4): S. Hoshino, K. Kohra* (present only on 15 August), Y. Saito (absent on 15 August), T. Sakurai* (present only on 15 August), S. Takagi, Y. Takéuchi (absent on 15 August).

Netherlands (3): P. T. Beurskens (present only on 7 August), D. Feil* (present only on 12 and 15 August), G. D. Rieck (absent on 12 August), C. Romers* (absent on 7 August), J. W. Visser (absent on 15 August).

New Zealand (1): P. P. Williams.

Norway (1): H. M. Seip (absent on 12 and 15 August), J. Hvoslef* (present only on 12 August).

Poland (1): J. Leciejewicz.

South Africa (1): G. Gafner (absent on 12 August), M. Laing* (present only for part of the session on 7 August, when he replaced G. Gafner, and on 12 August).

Spain (3): S. García-Blanco, M. Font-Altaba, R. Marquez. Sweden (2): S. Abrahamsson, P. Kierkegaard.

Switzerland (2): J. D. Dunitz, W. Nowacki.

U.K. (5): D. W. J. Cruickshank, M. Hart, O. S. Mills, D. C. Phillips (present only on 12 August), D. G. Watson* (absent on 12 August), A. J. C. Wilson.

U.S.A. (5): S C. Abrahams, R. D. Burbank, W. R. Busing, J. Karle, R. A. Young (replaced by L. H. Jensen* for part of the session on 12 August).

USSR (5): N. V. Belov, I. Y. Malinovsky* (present only on 8 and 15 August), M. A. Poray-Koshits (absent on 8 August), V. I. Simonov, S. P. Soloviev, V. I. Startzev (absent on 15 August)

Yugoslavia (1): D. Grdenić.

No delegates had been appointed by the Adhering Bodies in Argentina, Belgium and Chile.

Present as members of the Executive Committee: Dorothy Hodgkin (President; Chairman of the General Assembly), H. Jagodzinski (Vice-President), S. E. Rasmussen (General Secretary and Treasurer), A. Guinier (Immediate Past President), N. Kato, K. Łukaszewicz, A. Magnéli, A. McL. Mathieson, D. P. Shoemaker and B. K. Vainshtein (Ordinary Members). J. N. King (Executive Secretary) was also in attendance.

\section{First Session, Thursday 7 August 1975, 5.45 p.m.}

\section{(1) Introductory remarks by the President}

DOROTHY HODGKIN welcomed the delegates and the observers.

\section{(2) Procedural matters}

In order to verify the list of voting delegates, the President requested the General Secretary to read this list, and asked delegates to indicate their presence when their names were called. [This procedure was repeated at the beginning of each session of the General Assembly.]

Two delegates, L. D. Calvert (Canada) and S. GarcíaBlanco (Spain), were appointed to act as tellers when votes had to be counted during the Assembly.

\section{(3) Approval of Agenda}

The Agenda and Appendices to the Agenda had been distributed to Secretaries of National Committees on 26 May 1975. This Agenda was now approved by the delegates.

\section{(4) Application for membership of the Union}

The General Secretary explained that all the early stages of the application from Bangladesh had been completed satisfactorily. However, in spite of repeated requests from the Union, the Bangladesh Physical Society had not confirmed in writing either that it was willing to be the Adhering Body, or that it had accepted the membership of the National Committee for Crystallography which had been notified to the Executive Committee. Without this confirmation the General Assembly could not approve the application. The President had sent a reply-paid telegram to the Bangladesh Physical Society, and it was agreed to defer consideration of the application until a reply was received (see Minute 41).

\section{(5) Approval of Minutes of the Ninth General Assembly}

The Minutes were approved and two copies were signed by the President and the General Secretary, in accordance with By-Law 1.13. There were no matters arising from the Minutes.

\section{(6) Amendments to Statutes and By-Laws}

In accordance with Statute 13.1, the amendments to the Statutes and By-Laws proposed by the Executive Committee had been sent to National Committees and Commissions on 3 April 1975.

(a) On behalf of the Executive Committee, the Immediate Past President, Professor A. GuINIER, explained the motivation of the Executive Committee in proposing amendments to the Statutes and By-Laws to bring the length of service of Editors and Co-editors, as members of the Commissions set up for their respective publications, more in line with the length of service for members of other Commissions as already set out in By-Law 6.3. According to the present By-Laws, the continuous period of service by Editors and Co-editors was not limited, although for all other Commissions no person who has served for three consecutive full terms of office was eligible for nomination for a fourth consecutive term of office on the same Commission, except as Chairman. Although the Executive Committee could refuse to reappoint an Editor or to approve the reappointment of a Co-editor at present, Professor GUINIER suggested that it was preferable to have fixed limits to the length of service. However, the tasks and requirements of a Coeditor for one of the Union's journals were different from those of a member of a non-publishing Commission. A Co-editor required great experience and had to establish his own team of referees. Furthermore, the appointment of older, better-known crystallographers as Co-editors helped to attract good papers to the journals. It would be unwise to change the Co-editors too often.

If any limitations were to be introduced, it was first necessary to delete the last sentence of Statutes 7-1 and 7.2. 
which stated that the number of reappointments of Editors, Co-editors and Assistant Editors was not limited. The Executive Committee had also suggested two alternative amendments to By-Law 6.3, so that this By-Law might include a specification of the terms of service for Editors, Co-editors and Assistant Editors. However, Professor GuINIER explained that, after further careful consideration, the Executive Committee now wished to propose a third version, which limited the continuous length of service in any one office as Editor, Co-editor or Assistant Editor to nine years and the continuous membership of the Commission, in any combination of these positions, to fifteen years. It was not proposed that these limits should restrict the appointments or reappointments immediately, but rather that they should apply from the close of the next General Assembly.

In the ensuing debate several delegates spoke in favour of some restriction of the length of service, although there were considerable differences of opinion as to the best limits. Although a limit might be appropriate for the journals, it was suggested that its application to Structure Reports and International Tables might do irreparable harm. However, some delegates considered that, as the present Statutes gave the Executive Committee the power to control the length of service of individuals, the Executive Committee should make use of this authority when it felt it to be necessary. It was agreed to defer any decision on By-Law 6.3 until the third session of the General Assembly (see Minute 28), since 48 hours notice was required for the proposal of the new version of the amendment to By-Law 6.3 which the Executive Committee now wished to introduce. However, the proposal to delete the last sentence of Statutes $7 \cdot 1$ and $7 \cdot 2$ was approved by 41 votes to 16 , with one abstention. The amended Statutes and the ByLaws are given in Anney II.

(b) The Vice-President, Professor H. JAGODzINsKI, introduced proposed amendments to the By-Laws which would permit observers to remain present at any General Assembly session at which new members were to be admitted or questions of membership were discussed. The amendments would still allow for the withdrawal of observers and others in the rare event that there was controversy over adherence to the Union. These proposals were adopted unanimously.

\section{(7) Report of the Executive Committee}

The report of the Executive Committee on the activities of the Union since the Ninth General Assembly had been submitted to the National Committees and the Commissions in May 1975, in accordance with Statute 6.8, and follows these Minutes as Annex 1, Appendix A. The General Secretary drew attention to the five volumes of Structure Reports published in November 1974 and the five more volumes published in April 1975. Since the report had been written three more volumes, 37A, 37B and 38B, had been completed and were on display at the exhibition in the Congress Hall.

The report of the Executive Committee was accepted without discussion. The President adjourned the meeting at $7 \cdot 20$ p.m.

\section{Second Session, Friday 8 August 1975, 5.30 p.m.}

(8) Report of the Executive Committee

Although this report had been accepted at the first session of the Assembly some delegates had requested that further comment be given on the report. The General Secreatry noted that Anomalous Scattering, the proceedings of the conference held in Madrid in April 1974, had just been published and was on display in the Congress Hall. No other points were raised.

\section{(9) Financial Report}

A financial report, covering the calendar years 1972 , 1973 and 1974 had been prepared by the Treasurer and had been submitted to the National Committees and the Commissions in May 1975. This report follows these Minutes as Annex I, Appendix B.

The Treasurer drew attention to the balance of the Union's finances, which had dropped $7 \%$ between the end of 1971 and the end of 1974 for totals expressed in U.S dollars. However, if these totals had been expressed in Swiss francs, a currency which had been more stable during the last three years, then they would have shown a loss of $36 \%$.

The Acta Crystallographica and the Journal of Applied Crystallography accounts were reasonably satisfactory, although the steady increases in publication costs necessitated regular increases in subscription rates. For example, the Treasurer estimated that there would be a deficit of $\$ 76000$ for Acta Crystallographica in 1976 if the subscription rates were not increased from their 1975 values. It would be necessary to increase subscription rates by about $20 \%$ to avoid a deficit, allowing for a $10 \%$ increase in size of the journal in 1976. In answer to questions, the Treasurer explained that several steps had already been taken to reduce costs. The publisher's commission on current subscriptions to Acta Crystallographica had been reduced from $12 \frac{1}{2} \%$ to $10 \%$, and the stock of early volumes (Volumes 1-27) had been sold. Changes in production methods would be necessary to reduce the costs further by a significant amount.

The balance in the Structure Reports account had dropped dramatically with the concerted efforts to bring Structure Reports up to date. The fruits of this hard work were now appearing. Five volumes of Structure Reports were published in November 1974 and five more in April 1975. More volumes would be published later in 1975. Money spent on publishing these volumes should soon be recovered from sales.

The International Tables account showed a deficit at the end of 1974 because of the considerable investment made in the new series of International Tahles for Crystallography as well as the printing of Volume IV in the present series. S. C. ABRahams (U.S.A.) enquired whether any efforts had been made to obtain support from government agencies for the early stages of the computer trial project on the production of the new series. The Treasurer explained that the earliest work had really been an investigation to find out whether computer production was possible. Later on, when it was evident that it was possible, the expenses were considered as part of the publishing costs. When it was realized that the early estimates of the time scale had been rather optimistic, support was sought from various national funds. He was certain that any future computer trial projects, as research projects, could only be undertaken with the support of agencies outside the Union. He expressed the gratitude of the Union to the French Ministry of Scientific and Industrial Development for a grant of 80000 French Francs towards the publication of the volume on direct 
space in the new series, and he hoped that grants from other organizations might also be obtained.

The Molecular Structures and Dimensions series showed an appreciable profit. However, only $5 \%$ of the profit was retained by the Union; the remainder was passed on to the Cambridge Crystallographic Data Centre. The General Fund account showed a profit because fewer meetings had been arranged than were envisaged at the time of preparation of the budget. The financial report was accepted unanimously and, in accordance with Statute $5 \cdot 10(i)$, the Treasurer and any other Officer or Chairman of a Commission were released from financial or other liability to the Union.

\section{(10) Reports of the Commissions}

The reports of the Commissions and their activities since the Ninth General Assembly were distributed to the National Committees and the Commissions in May 1975, in accordance with Statute 8.4. They are reprinted as Annex 1, Appendix $\mathrm{C}$ to these Minutes. The reports were taken as read but the Chairman of each Commission, or his substitute, was invited to say a few words about any further developments and to answer any questions. These verbal reports are summarized in Minutes 11-13 and 15-24. Later reports of the work of the Commissions are summarized in Minutes $47-52$.

\section{(11) Commission on Journals}

The Chairman of the Commission and Editor of Acta Crystallographica A. J. C. WILsON, observed that the restriction of Section B to 2900 pages for 1974 had led to some pages being held over at the end of 1974. The same restriction was being applied in 1975, with the result that some papers which would otherwise have been published in November and December 1975 would not now be published until January and February 1976. He understood that the size of Section B would be increased for 1976, which should reduce this backlog, and that the subscription rates would also be raised.

Professor WILson reported that the Commission was seriously considering different methods of publication and the problems of the publication of structures. He hoped to be able to report some definite proposals at a later session of the General Assembly. The Journal of Applied Crystallography would go over to a different publication method during 1975.

T. M. SABIne (Australia) enquired about the possibility of sending the journals by air-freight to Australia and New Zealand. However, because of the small number of subscriptions involved it would be cheaper for individual subscribers to pay air-mail costs rather than air-freight costs. Arrangements for air-mail delivery of journals could be made directly with the publisher, Munksgaard.

S. C. AbRahams (U.S.A.) regretted that the cumulative ten-year index for 1958-1967 for Acta Crystallographica was being sold separately to subscribers, instead of being distributed free. He suggested that subscriptions should be adjusted to absorb the price of the cumulative indexes. It was explained that the index was being sold separately in order to measure the demand for cumulative indexes. If the demand was not significant then the compilation of these indexes might be discontinued. However, the preparation of a five-year index for the years 1968-72 had already been started.

J. KARLE (U.S.A.) enquired about the present opinion of the Executive Committee regarding the introduction of page charges. Professor WILSON observed that whilst page charges were paid begrudgingly in North America and with much more objection in the U.K., they were not usually paid in other countries. If the Union introduced page charges its journals would almost certainly not remain international in content. Dr KarLe suggested that the introduction of a time-lag penalty system for non-payment of page charges should be considered.

\section{(12) Commission on Structure Reports}

The Chairman of the Commission, J. Trotrer, suggested that delegates took the opportunity to inspect the latest volumes of Structure Reports on display. He reported that all remaining volumes, up to and including volumes for 1973 , were with the printer. It was noted that, whilst Structure Reports was 10 years behind in 1972, all volumes up to and including 1973 should be published by the end of 1975. A vote of thanks to W. B. Pearson, Chairman of the Commission between 1960 and 1972 and General Editor of the volumes covering the years 1953 and 1955 1970, and to J. Trotter, Chairman of the Commission since 1972 and General Editor of the volumes for 1971 onwards, was carried with applause.

In answer to a question from TH. HaHN (B.R.D.), Professor TrotTer expressed the belief that the yearly volumes, split into Part A and Part B, would continue to be published with the cooperation of the Cambridge Crystallographic Data Centre for the papers on organic structures.

\section{(13) Commission on International Tables}

The Chairman of the Commission and Editor of International Tables, TH. HAHN, reported that nearly 1000 copies of Volume IV, Revised and Supplementary Tables for Volumes II and III, had been sold since the volume was published in late 1974.

In September 1972 the Commission met in Grenoble to finalize its proposals for the new series of International Tables for Crystallography on symmetry, which it was intended to publish in three volumes. In 1974 the Executive Committee approved the Commission's proposal to publish the first volume in this series, on direct space. It was expected to submit the final computer tapes to the printer in the middle of 1976, after which work could be commenced on the second volume, on reciprocal space, subject to Executive Committee approval. The work on the reciprocalspace information would be a research project and it was hoped to undertake this work with the aid of a research grant.

\section{(14) Working Party on Information Services}

The General Secretary, who was Chairman of the working party, explained that its report had been sent out to delegates and Commission Chairmen at the beginning of July. The report is printed as Annex I, Appendix D, to these Minutes. He summarized the proposals made by the working party. TH. HAHN (B.R.D.) considered that more work was required in critical evaluation of both structural and non-structural data, and in abstracting in such fields as disorder and phase transformations.

In reply to a question from E. F. BerTaut (France), the General Secretary explained that, when the working party had prepared a list of publications, it had limited this list to publications of the Union and some abstracting services 
of use to crystallographers. It was not intended to be a comprehensive list, and he appreciated that many journals of interest to crystallographers had been omitted. This should not be interpreted as a slight on any journal, but rather as an indication of how wide the field of information was.

In reply to questions about a new edition of the World Directory of Crystallographers, the General Secretary said that this was the responsibility of the Executive Committee which had looked at various ways of preparing a new edition. The U.S.A. National Committee for Crystallography and the American Crystallographic Association had made proposals for financial support, but inflation had increased too rapidly and estimates of sales had been too low to enable these proposals to result in the publication of a reasonably priced edition. During its meeting in Amsterdam, the Executive Committee would examine alternative methods of publication.

\section{(15) Commission on Crystal Growth}

The Chairman of the Commission, P. Hartman, was unable to be present because of illness but N. KATO undertook to answer any questions. He reported that E. Kaldis had been appointed Union representative on the Organizing Committee concerned with problems of Physics and Chemistry in Space (subsequently known as the ad hoc group on Materials Sciences in Space), set up by the Committee on Space Research (COSPAR) of the International Council of Scientific Unions.

\section{(16) Commission on Crystallographic Apparatus}

The Chairman of the Commission, S. C. Abrahams, reported that a coordinated research project for studies on radiation damage, to be undertaken at three different laboratories, had been submitted to the U.S.A. National Science Foundation for consideration for financial support, whilst reports on the projects on small-angle scattering, powder intensity and microdensitometer measurements were being presented at the Congress.

\section{(17) Commission on Crystallographic Computing}

In this supplementary report, the Chairman of the Commission, F. R. AHMEd, said that a Summer School on Crystallographic Computing had just been held in Prague. It had been very successful although many requests to attend it had been refused, because the numbers had to be limited to about 230. It was hoped that the next Summer School would be held in India. A. VACIAGo (Italy) enquired whether the Union intended to start a bank for computer programs. Dr AHMED explained that this would be a very large task which could not be undertaken by the Commission without financial support.

The Commission had published a third edition of the World List of Crystallographic Computer Programs, but the response to requests for information about new programs had not been sufficient to merit the preparation of a supplement at present.

\section{(18) Commission on Crystallographic Data}

D. G. Watson, Chairman of the Commission, observed that, through him, the Commission had contributed to the report of the Working Party on Information Services. The information collected in the appendix to that report could form the basis of a report which might usefully be published, perhaps in one of the Union's journals. Such publica- tion might highlight the present deficiencies in the coverage of the field.

\section{(19) Commission on Crystallographic Nomenclature}

The Chairman, A. J. C. WILson, drew attention to the Open Meeting of the Commission which would consider the need for and scope of a crystallographic dictionary.

(20) Commission on Crystallographic Studies at Controlled Pressures and Temperatures

The report of the Commission was taken as read and there was no discussion.

\section{(21) Commission on Crystallographic Teaching}

C. A. TAYLOR, Chairman of the Commission, expressed his gratitude to the Congress Programme Committee for allowing Congress participants to submit a paper on teaching in addition to one on their research work. This should enable the Commission to organise a very fruitful and successful Open Commission Meeting.

\section{(22) Commission on Electron Diffraction}

The Chairman of the Commission, G. HoNjo, observed that the three sub-fields of electron diffraction (gas, low energy and high energy) had been well represented on the Commission, although their interests did not overlap very much. He drew delegates' attention to a meeting to be held in London in September 1977 to mark the fiftieth anniversary of the discovery of electron diffraction.

\section{(23) Commission on Neutron Diffraction}

L. M. Corliss, Chairman of the Commission, reported that a very successful meeting had been held in Petten, near Amsterdam, immediately prior to the Congress. The meeting had been devoted to new methods and techniques in neutron scattering.

\section{(24) Ad interim Commission on Charge, Spin and Momentum Densities}

The Chairman of the Commission, R. J. WeIss, explained that the Commission had initiated a large number of projects, including a Summer School which was held in Warwick a week before the present Congress, in order to delineate the areas in which it could best help the crystallographic community. If the establishment of the Commission was confirmed by the General Assembly, it was intended to hold another Summer School in the U.S.A. in 1976. Dr WeIss reported that the book by Dr B. G. Williams on Compton scattering was nearing completion. The project in which five laboratories in different parts of the world had measured the Compton profile of water had been useful. Over twenty laboratories had expressed an interest in taking part in a project to ascertain the accuracy of structure factors and Compton profiles, calculated from wavefunctions of various types and quality. The next Sagamore conference would be held in Finland in 1976. Dr WeIss hoped that the Commission would be continued.

(25) Review of the activities of the Commissions of the Union

As agreed at the Ninth General Assembly, the Executive Committee had examined the activities and problems of all the Commissions of the Union. The work of each nonpublishing Commission had been examined by one or more members of the Executive Committee, whilst the publishing Commissions had been considered separately by the whole 
Executive Committee. The results of these examinations were set out in a report to the General Assembly, which was distributed to National Committees and Commissions in May 1975 and follows these Minutes as Annex 1, Appendix E.

In general, the Executive Committee was satisfied that the Commissions were all serving the Union and the crystallographic community well, although it did make some constructive criticisms. R. A. Young (U.S.A.) believed that there had been a considerable improvement in the level of activity of most Commissions. He considered that this was a compliment to the Executive Committee. The report was accepted by the General Assembly without further discussion.

(26) Consideration of the need for a Commission on Charge, Spin and Momentum Densities

The Immediate Past President, Professor A. Guinier, suggested that this Commission, established on an ad interim basis following the Ninth General Assembly, had demonstrated admirably that there was a definite need for such a Commission. A VACIAGO (Italy), in supporting Professor Guinier's remarks, suggested that the Chairman of the Commission on Crystallographic Apparatus might be made an ex officio member of the Commission on Charge, Spin and Momentum Densities. The President considered this to be a useful suggestion to be borne in mind by the Commission and those concerned with its membership. The General Assembly agreed unanimously that the Commission should be established on the same basis as the other Commissions of the Union.

\section{(27) Size of Commissions}

In accordance with Statute $5 \cdot 10(d)$, the Assembly had to determine the number of persons to be elected on the Commissions until the Eleventh General Assembly. The Executive Committee did not propose any changes to the numbers of elected members, except of the newlyestablished Commission on Charge, Spin and Momentum Densities, for which it was proposed to increase the number of elected members from ten to eleven, in accordance with a request made by that Commission.

K. SASVÁRI (Hungary) proposed that the number of elected members for the Commission on Crystallographic Computing be increased from seven to eight, with the object of including an elected member from the same country as that of the Chairman. He felt that such an extra member would assist the work of the Commission. In reply, the General Secretary explained that the Chairman of the Commission, F. R. Ahmed, had not made any such proposal to the Executive Committee when they met a few days ago, nor had he mentioned that any such discussion had taken place within the Commission. Dr Ahmed was not present, but the General Secretary suggested that the present proposal of seven elected members should be retained. Should any subsequent increase in size be felt necessary, this could be done by appointing Consultants or co-opting further members.

The General Secretary reminded delegates that the numbers of elected members of Commissions had to be decided at this session of the Assembly if the elections were to be held on Tuesday 12 August, as was desired by the Executive Committee, in order to give the new Commission members a chance to meet during the Congress. The question of ex officio members did not have to be decided immediately.

The General Assembly approved the numbers of elected members of Commissions which were proposed by the Executive Committee, and which are set out below (Chairman of Commissions not included):

Commission on Journals

Commission on Structure Reports

Commission on International Tables

0

0

Commission on Charge, Spin and Momentum Densities 11

Commission on Crystal Growth

Commission on Crystallographic Apparatus

Commission on Crystallographic Computing

Commission on Crystallographic Data

Commission on Crystallographic Nomenclature

Commission on Crystallographic Studies at Controlled

Pressures and Temperatures

Commission on Crystallographic Teaching

Commission on Electron Diffraction

Commission on Neutron Diffraction

The President then adjourned the meeting at 7.50 p.m.

\section{Third Session, Tuesday 12 August 1975, 5.30 p.m.}

The President reported that she had visited Professor M. J. Bijvoet at his home on Sunday 10 August. He was very ill indeed. Her suggestion that a telegram should be sent to Professor Bijvoet on behalf of all the crystallographers present at the Congress and General Assembly was approved.

\section{(28) Amendments to the By-Laws}

Following the approval of amendments to Statutes $7 \cdot 1$ and 7.2 at the first session of the Assembly (Minute 6), it has been agreed to defer further consideration of amending By-Law 6.3 until the third session. The Immediate Past President, Prof. A. Guinier, read out the revised amendment which had recently been proposed by the Executive Committee, because it now felt that neither of the previous versions proposed was clear enough. The new version was as follows (new wording in italics and deletions in parentheses):

By-Law 6.3: No person shall normally serve for a continuous period of more than nine years in any one office as either Editor, Co-editor or Assistant Editor, and not more than a continuous period of fifteen years on one and the same publishing Commission. For persons appointed prior to the Tenth General Assembly these limitations shall only apply from the close of the Eleventh General Assembly. On other Commissions, no person who has served for three consecutive full terms of office on a Commission is eligible for nomination for a fourth consecutive term of service on the same Commission except as Chairman. On such other Commissions, in no case is any person eligible for more than four consecutive full terms of service on the same Commission. These limitations do not apply to (Editors [Statute 7.1], Co-editors [Statute 7.2] and) ex officio members. Any Commission, in its Rules of Procedure, may reduce the length of service specified here.

D. W. J. CRuICKshank (U.K.) opposed the amendment of By-Law $6 \cdot 3$, since he considered that sufficient had been done by the amendment of Statutes $7 \cdot 1$ and $7 \cdot 2$. Further- 
more, he and other delegates considered that the wording of the most recent modification was ambiguous. J. TROTTER (Canada), speaking as Chairman of the Commission on Structure Reports, supported the principle of limitation of terms of office, but expressed concern about its application to the Co-editors of Structure Reports. Under the proposed changes neither he nor any of his active Co-editors would be eligible for re-election in 1978. He believed that the new Editor of Structure Reports appointed then should be able to call upon the services of the most experienced $\mathrm{Co}$ editors. He suggested that the proposed limits to length of service could lead to the cessation of Structure Reports. The General Secretary observed that it was intended to implement a general principle, not a restrictive practice.

E. N. MASLEN (Australia) suggested that it would be unwise to proceed with the proposed amendments in view of the problems they would create for Structure Reports, but E. F. BERTAUT (France) observed that the Executive Committee would have the power to grant exemptions to the time limits. L. D. Calvert (Canada) considered that Structure Reports and International Tables, as secondary publications, might have quite different requirements to the Union's journals, regarding length of service of Editors and Co-editors. He suggested that the limitations should be applied to the people determining policy, not the people doing the work. P. P. Williams (New Zealand) proposed that the consideration of amendments to By-Law $6 \cdot 3$ should be deferred to the Eleventh General Assembly. Twenty-seven votes were received for and twenty-seven votes against this motion. The motion was carried on the casting vote of the President (see also Minutes 30 and 56).

The President thanked delegates for making the advantages and disadvantages of applying limitations to the length of service evident to the Assembly.

\section{(29) Confirmation of the appointment of the Editors of the publications of the Union}

In accordance with Statute $7 \cdot 1$, the initial appointments and the reappointments of the Editors of the publications of the Union were made by the Executive Committee and were subject to confirmation by the General Assembly. The Assembly unanimously confirmed the following reappointments for a period of three years;

Editor of Acta Crystallographica:

$$
\text { A. J. C. Wilson (U.K.) }
$$

Editor of the Journal of Applied Crystallography:

$$
\text { R. A. Young (U.S.A.). }
$$

At the Ninth General Assembly Professor J. Trotter (Canada) had been appointed Editor of Structure Reports and Professor Th. Hahn (B.R.D.) had been appointed Editor of International Tables, both for a period of six years.

\section{(30) Election of Chairmen and members of Commissions}

At recent General Assemblies, all the elections had been held at the final session of the Assembly, just before the Congress Closing Ceremony. Acting on suggestions from the Commissions, the Executive Committee proposed that the elections for Commissions should be held earlier in the Assembly, so that the newly elected members of Commissions would have the opportunity to meet in Amsterdam. The nominations made by the Executive Committee for Chairmen and members of Commissions had been notified to the delegates (and alternates) on 9 August, more than 24 hours earlier than the deadline required by By-Law
$7 \cdot 3$ for the elections to be held at the present session of the Assembly.

The President explained that the nominated Chairman for the Commission on Crystallographic Apparatus might subsequently wish to resign, in which case a new nomination would be placed before the General Assembly at the final session (see Minute 43).

S. C. Abrahams (U.S.A.) wished to raise the general question of the time-table for nominations. Delegates had only been given the nominations of the Executive Committee shortly before being required to vote. He considered that the Executive Committee could have presented these nominations two months earlier, thereby enabling National Committees to consider these nominations. D. W. J. CRuICKSHANK (U.K.) did not think that the Executive Committee's nominations, particularly nominations for Commissions, would have been so well thought out if two months' notice was required. J. KaRLE (U.S.A.) appreciated that there might be limitations, but he would prefer to receive longer notice.

The President explained that the Executive Conmittee discussed its nominations for the Commissions with the Commission Chairmen, and it also discussed its nominations for the officers of the Executive Committee at the meetings of the Executive Committee held immediately before the Congress. It then presented these nominations to the delegates. The President observed that in October 1974 she had asked all National Committees for suggestions for nominations for the Executive Committee and the Commissions. Replies had been received from only ten National Committees, which was not a very high level of response. She also reminded delegates that the elections for Commission memberships were intentionally being held earlier in the present Assembly, at the request of some Commissions and National Committees, to enable the new Conmission members to meet in Amsterdam, but it was now apparent that this action also led to difficulties. T. $M$. SABINE (Australia) supported this attempt to secure the opinions of National Committees. S. C. ABRAHAMS (U.S.A.) and TH. HAHN (B.R.D.) suggested that it would be helpful if nominations for the Executive Committee, and at least for the Chairmen of Commissions, could be communicated to delegates at the beginning of the General Assembly. Following a suggestion by Professor D. P. SHOEMAKer, M. Font-Altaba (Spain) proposed that a sub-committee be set up to examine Statutes and By-Laws. After some discussion about terms of reference, it was agreed that the Executive Committee should appoint a sub-committee to scrutinize the present Statutes and By-Laws in general, although it was appreciated that this would include the questions of the time-table for nominations and the amendment of By-Law 6.3. The sub-committee should make any recommendations for amendments to the Executive Committee, for communication to the National Committees and for consideration at the Eleventh Assembly in 1978. (The Assembly was informed of the membership of the sub-committee at its final session; see Minute 56).

With the exception of the finalization of the Chairmanship of the Commission on Crystallographic Apparatus, and in the absence of other nominations being made by delegates, all persons nominated by the Executive Committee as Chairmen and members of Commissions were considered as elected. According to Statute $7 \cdot 3$, the Editors and Co-editors are automatically members of the Commis- 
sions set up for the publications concerned. The Commission on Crystallographic Nomenclature consists of the Editors of Acta Crystallographica, Journal of Applied Crystallography, Structure Reports and International Tables with the first-named Editor as Chairman.

The full memberships of the Commissions including ex officio members, together with the addresses of the Chairmen, are given in Annex III.

\section{(31) Election of Representatives on bodies not belonging to the Union}

As no other nominations had been made by delegates, all persons nominated by the Executive Committee were considered as elected. The names and addresses of the Representatives of the Union, including those appointed ex officio, are given in Annex III.

\section{(32) Reports from Representatives on bodies not belonging} to the Union

In accordance with Statute $8 \cdot 5$, the reports of the Representatives on bodies not belonging to the Union had been submitted to the National Committees and to the Commissions in May; they are printed as Annex I, Appendix F to these Minutes. The reports were taken as read, but the Representatives were invited to inform the Assembly of any further developments.

The representatives on the IUPAP Commission on the Solid State, the ICSU Committee on Data for Science and Technology, and the ICSU Committee on the Teaching of Science had nothing to add to the written reports and were not asked any questions by delegates. The representative of the Conference Committee of the European Physical Society was unable to be present.

\section{(33) International Organization for Crystal Growth}

N. KATO, deputizing for P. Hartman, the Union representative, had nothing to add to the written report. A. Authiner (France), the newly-elected Chairman of the Commission on Crystal Growth, proposed that a representative from the International Organization for Crystal Growth be appointed as an ex officio member of the Commission. The General Assembly approved this suggestion.

\section{(34) ICSU Abstracting Board}

A. J. C. WILson reported that he had represented the Union at the ICSU Abstracting Board meeting held in Brussels in June 1975. This meeting included a symposium on the provision of information services to the developing countries. What many of these countries needed was the social and economic information that would enable them to decide what technical aid they really needed. Such information was not readily available at present.

The Abstracting Board also devoted considerable attention to matters such as synopsis journals, microfiche supplements, alternative forms of publication, and the impact of tape information on the more conventional information services. This information had been of help to the Commission on Journals, and Professor Wilson had also passed it on to some other Commissions.

(35) ICSU Committee on Space Research. Organizing Committee concerned with problems of Physics and Chemistry in Space (subsequently known as the ad hoc group on Materials Sciences in Space)

Although the Union representative, E. Kaldis, was un- able to be present, he had attended a COSPAR meeting in Varna, Bulgaria in June 1975. He had informed the General Secretary that a very interesting programme could develop, including studies of crystal growth under zerogravity conditions. The organizing committee would be holding a two-day symposium in 1976, at the time of the COSPAR Conference in Philadelphia, U.S.A.

\section{(36) IUCr-IMA Joint Committee on Nomenclature}

H. Schulz deputized for the Chairman of this joint Committee of the Union and the International Mineralogical Association, S. W. Bailey, whose report was taken as read and is given as Annex $\mathrm{I}$, Appendix G.

\section{(37) Sub-committee on the Union Calendar}

A summary of the activities of the Sub-committee was distributed with the General Assembly papers in May, and is given as Annex I, Appendix H. The Chairman of the Sub-committee, A. McL. MATHIESON, reminded delegates that one of its initial objectives was to relieve the strain on the triennial Congresses by assisting the organization of small meetings. In some cases it was able to recommend token financial support. The Sub-committee had tried to make some assessment of the influence of economic forces which came into effect in late 1973 and early 1974. In general any effect on small meetings had been rather small. The influence had been more noticeable for medium-sized meetings.

At their meetings in Amsterdam, the Sub-committee and the Executive Committee had so far approved Union sponsorship for four meetings in 1976 and three meetings in 1977. In answer to questions, Dr MATHIESON considered that both the moral backing provided by Union sponsorship and the financial support of the Union were of considerable practical assistance. Although even token financial support was helpful, it was generally not offered when a series of meetings had become well established.

\section{(38) Discussion of the future policy of the Union}

Statutes $5 \cdot 10(\mathrm{l})$ and $5 \cdot 10(\mathrm{~m})$ require the General Assembly to determine the general policy and the time-table for the period to the next General Assembly, and to give preliminary consideration to the activities of the Union for the three-year period following that General Assembly.

Dr Mathieson had already reported that a good number of future meetings had been given Union sponsorship. E. F. Bertaut (France) and E. N. Maslen (Australia) suggested that the Chairmen of the Union's Commissions should meet during the Congress. A. VACIAGo (Italy) suggested that the session Chairmen for the Congress should also meet to discuss their experiences, particularly with respect to the poster sessions.

\section{(39) Budget estimates for the period until the Eleventh General Assembly}

The budget estimates for the General Fund for the threeyear period 1975-1977 had been sent to the National Committees and the Commissions in May; they are printed as Annex I, Appendix I. The budget was based on an increase of the unit contribution to $\$ 220$ for 1976 and 1977, which was believed to be acceptable to most Adhering Bodies.

The Treasurer explained that the yield from investments and bank accounts was decreasing steadily, and its effective value was being eroded by inflation. It was therefore 
necessary to call for an increase in the unit contribution. in order to prevent the Union's activities being curtailed greatly. Unfortunately, even with an increase in the unit contribution to $\$ 220$, it would be necessary to reduce considerably the financial support available for scientific meetings, if an excessive deficit was to be avoided for the General Fund. It was almost impossible to decrease expenditure for the other activities covered by the General Fund.

W. R. BusING (U.S.A.) advocated increasing the unit contribution beyond $\$ 220$, in order to continue support of meetings at the present level. However, other delegates explained that they were not empowered to approve an increase in the unit contribution above the figure of $\$ 220$ proposed by the Executive Committee and notified to National Committees in May. Some delegates raised the possibility of obtaining funds from other sources, specifically for use in support of scientific meetings or for the support of special projects. A. J. C. WILSON (U.K.) warned that it was possible that the United Kingdom might decide to reduce its category of adherence to that of other countries of similar size and population.

D. W. J. CRUICKSHANK (U.K.) expressed concern at the proposed low level of support for scientific meetings. He noted that the budget for administrative meetings had increased from $\$ 28000$ in the last triennium to $\$ 44000$, an increase of about $60 \%$, whilst the budget for scientific meetings had decreased from $\$ 30000$ to $\$ 20000$, a decrease of $33 \%$. He suggested that the support for scientific meetings should be increased by $\$ 10000$ and, correspondingly the deficit on the General Fund for the triennium should be increased to $\$ 13000$, since the General Fund had shown a profit of $\$ 30000$ for the last triennium. The Treasurer expressed sympathy for the suggestion but opposed the idea of amending the budget so that it showed a substantial deficit.

After further discussion, the budget estimates were approved but with the request that the Executive Committee do all in its power to increase support of scientific meetings above the budgeted figure of $\$ 20000$.

(40) Unit contribution for the period until the Eleventh General Assembly

According to Statute $5 \cdot 10(k)$, the General Assembly had to determine the unit contribution for the period to the next General Assembly. Advance warning of a likely increase had been given to National Committees in September 1973, and the detailed proposal of the Executive Committee had been communicated in August 1974. The Executive Committee proposed, on the basis of the General Fund budget just discussed, that the unit contribution be increased from 1 January 1976 to $\$ 220$ for the years 1976 , 1977 and 1978. There had already been considerable discussion of the unit contribution, in relation to the budget estimates (see Minute 39), and the proposal to increase the unit contribution to $\$ 220$ for 1976,1977 and 1978 was approved with only three votes against.

The President then adjourned the meeting at 8.00 p.m.

\section{Fourth Session, Friday 15 August 1975, 2.15 p.m.}

\section{(41) Application for membership of the Union}

The President reported that no reply had been received to the telegram to the Bangladesh Physical Society, and therefore the application from Bangladesh for membership of the Union would be postponed to the Eleventh General
Assembly. It was learned later that postal communications with Bangladesh had been discontinued during the time of the Congress.

\section{(42) Election of Officers of the Union}

In accordance with By-Laws $2 \cdot 2$ and $7 \cdot 1$, the nominations made by the Executive Committee for Officers of the Union had been notified to delegates (and alternates) on 11 August. A. Magnéli had been elected an ordinary member of the Executive Committee at the Ninth General Assembly, to serve until the close of the Eleventh General Assembly. In accordance with By-Law 2.2, the Executive Committee had nominated $K$. Kuchitsu to fill the vacancy created, for the period to the Eleventh General Assembly, if Professor Magnéli was elected President. Some of the delegates had made additional nominations for the office of ordinary member. These nominations had been submitted in accordance with the procedure specified in ByLaw $7 \cdot 2$.

The President reported that, in October 1974, National Committees had been invited to submit suggestions for Officers of the Union. Altogether, four suggestions were received for the office of President, two for Vice-President, one for General Secretary and Treasurer, and 32 for ordinary members of the Executive Committee. These included all the persons finally proposed by the Executive Committee, after lengthly consideration, and also the two persons nominated by delegates. The President concluded that there were very many people to choose from, and clearly not everyone could be nominated this time.

Both of the nominations made by delegates for the office of ordinary member were specifically for a full (six-year) period of service. The General Secretary and Treasurer noted that the President had informed him that, in the past, a procedure had been adopted in which both types of vacancy were open for election simultaneously. He asked whether the delegates who had made the nominations were aware of the differences between the vacancies and whether they wanted their candidates to stand for the sixyear period only, and not the three-year period. E. N. MASLEN (Australia), for the proposers, replied that the nominations had been deliberately made for the six-year period only. The President asked whether the delegates were happy to leave the position as it was. She suggested that, another time, different arrangements might be made. A. J. C. WILSON (U.K.) observed that, since the candidates had been nominated specifically for the six-year period, the requirements of the Statutes and By-Laws did not permit the Assembly to consider these nominations now for the three-year period.

As no nominations had been made by delegates for the other Officers of the Union, the following were considered elected:
President: A. Magnéli (Sweden)
Vice-President: B. K. Vainshtein (USSR)
General Secretary and Treasurer:
Ordinary member: K. Kuchitsu (Japan)
S. E. Rasmussen (Denmark)

A. MCL. MATHIESON, a retiring member of the Executive Committee, commented on the present methods of nomination and election. He reminded delegates that the Executive Committee had, in fact, sought the opinions of all National Committees, and had considered every suggestion made when it devoted a considerable amount of its time in 
Amsterdam, prior to the Congress, to deciding upon its own nominations, particularly its nominations for Officers of the Union. It had taken its duties very seriously. It had a great responsibility to the Union, especially regarding the financial aspects of its activities. He considered that, under these circumstances, the proposal of counter nominations by delegates implied a lack of confidence in the Executive Committee. The membership of the Executive Committee had to be considered as a whole and not as a collection of individuals. The Executive Committee had attempted to maintain a good balance of interests and talents with its nominations; counter nominations, however well-intentioned, could upset this balance significantly.

J. KARLE (U.S.A.) considered that it was a proper, legal act for delegates to submit additional nominations, and that it was in no way demeaning. He felt that it was regrettable that anyone should consider it to be so.

Copies of the By-Laws regarding the procedure for the election of officers of the Union had been distributed to all delegates, prior to this session of the Assembly. Ballot papers were then distributed, and the General Secretary explained the voting procedure for the three vacancies for ordinary members of the Executive Committee. F. R. Ahmed (Canada), E. F. Bertaut (France) and $S$. Ramaseshan (India) had been nominated by the Executive Committee. F. H. Herbstein (Israel) and A. Vaciago (Italy) had been nominated by delegates. In the first ballot only three candidates received more than the 31 votes required for a simple majority, and hence they were declared elected as ordinary members of the Executive Committe, to serve until the end of the Twelfth General Assembly. They were F. R. Ahmed (49 votes), E. F. Bertaut ( 42 votes) and S. Ramaseshan (40 votes). A Vaciago received 21 votes and F. H. Herbstein 18 votes.

The full membership of the Executive Committee is given in Annex III.

\section{(43) Election of the Chairman of the Commission on Crys- tallographic Apparatus}

After his election as a member of the Executive Committee, Dr S. Ramaseshan resigned as Chairman of the Commission on Crystallographic Apparatus and was nominated as an ordinary member of the Commission. Professor R. Rudman was then nominated as Chairman of the Commission and both he and Dr Ramaseshan were declared elected.

\section{(44) Date and place of the Eleventh General Assembly}

The President reported that six invitations, of various degrees of formality, had been received. At the time of the last Congress three invitations had been received, from Spain, India and the B.R.D. The Executive Committee considered where it might be most helpful to meet for the benefit of crystallographers who had not been able to meet before. India was tentatively chosen, whilst Spain was asked to host a meeting in Madrid and the invitation from the B.R.D. was deferred to a later occasion. It then became rather difficult to arrange the Congress in India for various reasons, and three more tentative invitations had been received from Canada, Norway and Poland. After consideration of all the various factors, The Executive Committee had accepted the invitation from Poland, subject to the approval of the General Assembly.

On behalf of the Polish Academy of Sciences, Dr K. LUKASZEWICZ invited the Union to hold its Eleventh
General Assembly and International Congress of Crystallography in Poland in 1978, probably in Warsaw in August. Attention was drawn to the Congress of the International Mineralogical Association which would also be held in the summer of 1978 . It was requested that any clash in dates should be avoided, if possible. A. J. C. WILson (U.K.) expressed his gratitude to his Polish colleagues but observed that at least two member countries of the Union had expressed grave doubts as to whether they would be allowed to attend a Congress in Poland. He enquired whether the President of the Union had contacted the President of the Polish Academy of Sciences and obtained any assurances of the availability of visas. The President replied that she had not had any direct contact. However, although it was impossible to forsee the situation in the future, Dr LuKASzEWICZ and the delegate from Poland, Dr J. Leciejewicz, confirmed that the Polish Academy of Sciences supported the free circulation of scientists.

E. N. MASLEN (Australia) requested that the smaller countries and those far distant from Poland should be given as much advance notice as possible of the dates of the Congress and of registration requirements for participants, so that all necessary formalities could be completed in time. W. TRAUB (Israel) expressed his pleasure at the invitation to hold a Congress in Poland, but also drew attention to the difficulties which could arise. Scientists from distant countries were advised to ensure that they made their applications for visas in good time, sending copies to the General Secretary of the Union and to the Congress Organizing Committee, who should also be kept informed at all stages. The Union would do all that it could to help overcome any difficulties which might arise. E. F. BERTAUT (France) enquired how early applications should be made by participants from countries such as Israel. Dr EUkASzEwICZ did not know, but he suggested that a few months might be needed.

The invitation from the Polish Academy of Sciences was accepted with acclamation.

\section{(45) Free circulation of scientists}

During the discussion of the date and place of the Eleventh General Assembly (Minute 44), attention was drawn to the guidelines adopted by the 15 th ICSU General Assembly, held in Istanbul, Turkey, in September 1974, regarding the free circulation of scientists and the sponsorship of meetings. A number of cases had been reported to ICSU when bona fide scientists from member countries of Unions had recently been prevented from attending symposia organized or sponsored by these Unions through a refusal to grant entry visas. These guidelines had recently been accepted by the Executive Committee of the IUCr. The President read out the following principles which had been adopted by IUPAC and subsequently had been supported by the International Council of Scientific Unions:

(i) Applications for visas, where necessary, should be made to the appropriate authorities not less than three months before the date of the symposium or meeting. If these visas are not granted or promised in writing one month before the date of the event, then sponsorship should be withdrawn.

(ii) Arrangements for future meetings in any country found unable to comply with these principles should be suspended until more satisfactory circumstances exist. 
These principles were accepted by the Assembly without further debate.

\section{(46) Reports of the Commissions, continued}

In addition to the reports which had already been presented to the Assembly at its second session (see Minutes 11-13 and 15-24), the Chairmen of the Commissions, or their substitutes, were invited to give additional reports on the results of their Commission meetings in Amsterdam. These reports are recorded in the following Minutes 47-52.

\section{(47) Commission on Journals}

The Chairman of the Commission and Editor of Acta Crystallographica, A. J. C. WILson, reported that the Commission had met four times and had decided to look into the use of computer-controlled, optical typesetting for the composition of the journals, with the aim of using this method of typesetting if it was economically advantageous. The earliest date that this method could be introduced was January 1977. The Commission was not considering the introduction of a synopsis journal at present, and it did not wish to be associated with the publication of journals containing papers which had not been refereed. The acceptance of papers on the teaching of crystallography would be considered, normally for publication in Section A of Acta Crystallographica. It was intended to change the name 'Short Structural Papers' to 'Standard Structural Papers', as from the beginning of 1976. J. D. DunITz (Switzerland) did not favour the proposed change, but no other delegates expressed an objection to the proposed change in name.

The Co-Chairman of the Commission and Editor of the Journal of Applied Crystallography, R. A. YounG, reported that, from October 1975, this journal would be set with a filmsetter. He hoped that the use of computerized typesetting, as mentioned by Professor Wilson, would reduce the cost of printing and typesetting by at least $33 \%$. At least three Co-editors of the Journal of Applied Crystallography would be retiring within the next few months and Professor Young announced that he would be pleased to receive suggestions for new Co-editors.

\section{(48) Commission on International Tables}

The Chairman of the Commission, TH. HAHN, reported that it had met at least six times during the period of the Congress. It had discussed, considered and revised the layout and arrangement of material for the future edition of International Tables for Crystallography, although the content remained essentially unchanged. Professor HaHN thanked the Executive Committee for agreeing to Mr Fokkema commencing the preparation of the volume on reciprocal space, subject to a suitable research grant being obtained.

(49) Commission on Charge, Spin and Momentum Densities

The new Chairman of the Commission, E. F. Bertaut, attributed the high degree of activity of the Commission in the short period since its creation to $R$. J. Weiss, the retiring Chairman.

\section{(50) Commission on Crystallographic Apparatus}

In the absence of the new Chairman of the Commission, R. Rudman, S. RAMASESHAN reported that the Commission had met at least four times during the Congress, in addition to a few informal meetings, and that the activity of the Commission was a tribute to the enthusiasm and guidance given by the retiring Chairman, S. C. Abrahams. The
Open Commission Meetings had been very well attended.

\section{(51) Commission on Crystallographic Data}

The Chairman of the Commission, D. G. Watson, reported that the Commission had met twice and hoped to meet next year at the time of the Third European Crystallographic Meeting. The Commission would like to know of any laboratories which had private files of inorganic structural data.

\section{(52) Commission on Crystallographic Teaching}

The Chairman of the Commission, C. A. TAYLOR, reported that the Commission hoped to hold a Summer School in 1977, mainly for university teachers from developing countries. The Commission also wished to encourage the preparation of short pamphlets on specific topics. These pamphlets would be of particular use to crystallographers from developing areas.

\section{(53) Fifth Edition of the World Directory of Crystallographers}

The General Secretary explained that the Executive Committee had given detailed consideration to attempts to compile a fifth edition of this directory over recent years, and had appointed Dr S. C. Abrahams (U.S.A.) as General Editor. In order to minimize expense, it was hoped to distribute the workload widely and to collect the required information on punched cards, which would be prepared by the Sub-editors for each country. With the support of a commercial company, and by the use of inexpensive printing, binding and distribution methods, it was hoped that the price of the new edition might be held down to about \$2. Dr Abrahams would soon be communicating with the Sub-editors, perhaps adopting an experimental approach until he could decide on a final format. A major advantage of having the directory on a computer base was that it could be kept up to date relatively easily. L. D. CALvert (Canada) suggested that the General Secretary should write to all National Committees, urging them to maintain an up-to-date list of crystallographers in their own countries. Dr ABRaHams explained that the purpose of using a computer base for the directory was to be able to make the production of subsequent editions easier. It would also be possible to provide such things as addressed labels for Union officers or organizers of meetings.

\section{(54) International Status of the Union}

E. N. MASLEN (Australia) noted that Bangladesh was being encouraged to join the Union and hoped that China might join one day. He hoped that the Executive Committee would encourage countries which had not been able to send delegates to the present General Assembly to take a more active part in the future. He observed that several eminent scientists from countries not belonging to the Union at present had attended the Congress, and he suggested that, in future, such scientists might receive a special invitation to attend the General Assembly, in the hope that these countries might join the Union at some time in the future. The General Secretary reported that action along these lines had already been taken.

\section{(55) Establishment of a President's Fund}

The President suggested that a special fund might be set up, in memory of past Presidents, for use in emergencies and under difficult circumstances, particularly to assist 
those countries which found it difficult to provide the necessary money for participation in the Union's activities, and where the partial support normally offered by conference organizers was not sufficient to enable a scientist to attend a meeting. The fund would be operated by the President and by the General Secretary and Treasurer. The President's suggestion was well received.

\section{(56) Sub-committee on Statutes and By-Laws}

In accordance with the wishes of the General Assembly (Minute 30), the Executive Committee had appointed a sub-committee to examine the Statutes and By-Laws, with the following membership: The General Secretary (Chairman), D. W. J. Cruickshank and D. P. Shoemaker.

(57) Programme Committee for the Eleventh International Congress of Crystallography

The General Secretary reported that Dr K. Lukaszewicz had been appointed by the Executive Committee as Chairman of the Programme Committee. The President then adjourned the meeting at 3.45 p.m. for the Closing Ceremony which followed a few minutes later.

\section{Closing Ceremony, Friday 15 August, 4.00 p.m.}

Many members of the Congress attended this ceremony.

\section{Exhibition of photographs and drawings}

On behalf of the organizers of the exhibition of photographs and drawings of crystallographic interest, $H$. VAN KoniNGSveld presented charters for the most attractive exhibits to Jiři Komrska (Brno, Czechoslovakia) and J. M. A. Buiskool Toxopeus (Leiden, The Netherlands). He also presented a special prize to B. Watkins (Cardiff, U.K.) for his artistic photographs based on optical transforms, prepared at Professor C. A. Taylor's laboratory.

\section{Votes of thanks}

The following votes of thanks were approved with acclaim:

(a) K. SASVÁRI, the delegate from Hungary, spoke on behalf of all the participants at the Congress. He thanked the Stichting voor Fundamenteel Onderzoek der Materie met Röntgen- en Elektronstralen (FOMRE) and the Royal Dutch Chemical Society (KNCV) for their kind invitation to hold the Congress and General Assembly in Amsterdam. He thanked the Organizing Committee, D. Feil (Chairman), P. B. Braun (Vice-Chairman), H. M. Rietveld (Secretary and Treasurer), R. Olthof, D. G. Rieck and H. Schenk, for taking such excellent care of all the planning and organizational requirements that the participants could concentrate happily on the scientific activities. He thanked the Programme Committee and particularly its Chairman, A. Vos. Although it was impossible to thank everyone, he made special reference to the excellent work of the commercial conference agency, Organisatie Bureau Amsterdam, and the Poster Committee, which had organized the poster sessions so successfully.

(b) H. JAGODZINSKI, the retiring Vice-President of the Union, suggested that the number of problems for the organizers rose rapidly with the increase in the size of a meeting. On behalf of the Executive Committee, he thanked each member of the Organizing Committee, the 21 members of the eight Sub-committees, and the many additional helpers who had handled every detail of the Congress so magnificently. He also expressed his appreciation of the work of the Programme Committee [A. Vos (Chairman), A. Authier, P. Coppens, R. Sadanaga, V. I. Simonov, A. Vaciago, P. M. de Wolf, M. M. Woolfson] for the excellent arrangements of oral lectures and poster sessions.

(c) The newly-elected President, A. Magnéli, was introduced by the retiring President. During his speech, Professor MAGNél paid tribute to Professor Arne Westgren, who had died in March 1975 and had served the Union as one of its first Vice-Presidents. Professor MAGNÉLI expressed his appreciation of the work of the retiring President, Professor Hodgkin, the members of the Executive Committee who were retiring, Professor H. Jagodzinski, Professor A. Guinier, Professor N. Kato and Dr A. McL. Mathieson, the continuing members of the Executive Committee, and the Union secretariat. He emphasized the need for responsibility in all aspects of the work of the Union and the crystallographic community, keeping in mind that the ultimate goal of science was to serve human values and all human beings.

On behalf of the Organizing Committee, Professor $\mathbf{D}$. FeIL thanked the speakers for their kind expressions of gratitude. He endorsed their appreciation of the assistance given by the crystallographic community in the Netherlands, and by the Organisatie Bureau Amsterdam.

The retiring President, Dorothy HoDGkin, expressed the gratitude of the Union and the whole crystallographic community to Mr S. A. Bryant, Technical Editor of the Union's journals since 1962, who would be retiring from this position at the end of 1975 . She then declared the Tenth General Assembly and Congress officially closed at about $4 \cdot 35$ p.m. 


\section{ANNEX I}

\section{Appendices to the Agenda of the Tenth General Assembly}

\section{Appendix A: Report of the Executive Committee}

\section{Memorial notes}

The Executive Committee wishes to begin this report by recalling that, since the Ninth General Assembly, the crystallographic community has lost several of its members. As any list would be incomplete, only two names are mentioned here.

Dr Walter C. Hamilton died on 23 January 1973, after a brief illness. He had been a Co-editor of Acta Crystallographica since 1969 and, with Professor Ibers, he was editing Volume IV of International Tables for $X$-ray Crystallography, which was published in 1974. At Brookhaven National Laboratory he had built up a leading research group in the application of X-ray and neutron diffraction to many problems in chemistry and biology.

Dr Barrie Dawson died suddenly on 20 February 1974. He was a member of the Union's ad interim Commission on Charge, Spin and Momentum Densities and was the original Chairman for one of the three topics of the Conference on Diffraction Studies of Real Atoms and Real Crystals, which was held in Melbourne, Australia, in August 1974. He was internationally renowned for his introduction of the concept of anti-symmetry to describe non-centrosymmetric atomic charge and vibrational attributes, and his development of a generalized atomic scattering function.

\section{Meetings}

Since the Ninth General Assembly and International Congress of Crystallography in Kyoto, many meetings have been held, or will be held prior to the Tenth Congress, under the sponsorship or co-sponsorship of the Union. These meetings are: Third International Symposium on the Chemistry of the Organic Solid State, Glasgow, U.K., 18-22 September 1972; Symposium on the Structure of Biological Molecules, Stockholm, Sweden, 9-11 July 1973; Sagamore IV, Minsk, USSR, 13-18 August 1973; Third International Conference on Small-Angle Scattering, Grenoble, France, 5-7 September 1973; First European Crystallographic Meeting, Bordeaux, France, ;5-8 September 1973; Third International Meeting on Ferroelectricity, Edinburgh, U.K., 10-14 September 1973; Fourth International Conference on Crystal Growth, Tokyo, Japan, 24-29 March 1974; Second International Spring School on Crystal Growth, Mount Fuji District, Japan, 31 March-7 April 1974; Conference on Anomalous Scattering, Madrid, Spain, 22-26 April 1974; International Discussion Meeting on Studies of Lattice Distortions and Local Atomic Arrangements by X-ray, Neutron and Electron Diffraction, Jülich, B.R.D., 29 April-3 May 1974; Symposium on Intra- and Intermolecular Forces, Pennsylvania State University, U.S.A., 14-16 August 1974; International Crystallography Conference on Diffraction Studies of Real Atoms and Real Crystals, Melbourne, Australia, 19-13 August 1974; Second European Crystallographic Meeting, Keszthely, Hungary,
26-29 August 1974; Fourth International Symposium on the Organic Solid State, Talence, France, 17-19 July 1975; Summer School on Electron Charge, Spin and Momentum Density, Coventry, U.K., 27 July-2 August 1975; International Summer School on Crystallographic Computing, Prague, Czechoslovakia, 28 July-5 August 1975; Neutron Diffraction Conference, Petten, The Netherlands, 5-6 August 1975.

The Executive Committee met in Kyoto, Japan, on the occasion of the Ninth General Assembly, in Aarhus, Denmark, 3-5 July 1973 and in Manchester, U.K., 2-5 July 1974.

At the meeting in 1973 the most important items of business were: (1) the accounts for 1972, the future estimates for the General Fund and the need to increase the unit contribution at the next General Assembly; (2) subscription rates and other matters concerning the Union's journals, including the decision to offer the earlier volumes for sale at greatly reduced prices for a limited period; (3) the meeting of the Commission on International Tables being held in September 1973 to consider the responses to the Pilot Issue; (4) the interim report on the Working Party on Information Services; $(5)$ the proposals for a Fifth Edition of the World Directory of Crystallographers and for a crystallographic dictionary; (6) sponsorship of meetings; (7) plans for the Tenth General Assembly and International Congress of Crystallography and (8) the work of ICSU.

At the meeting in 1974 the main items considered by the Executive Committee were: (1) the audited accounts for 1973 and the estimates for the General Fund; (2) the proposed unit contribution for 1976-78; (3) many matters concerning the Union's journals, including size, delays in invoicing, subscription rates and methods of publication; (4) the publication of several volumes of Structure Reports; (5) proposals for a new series of International Tables for Crystallography; (6) revised proposals for a Fifth Edition of the World Directory of Crystallographers; (7) reprinting Symmetry Aspects of M.C. Escher's Periodic Drawings; (8) a review of the work of the Union's Commissions; (9) an application from Bangladesh for membership of the Union; (10) plans for the Tenth General Assembly and International Congress of Crystallography and (11) sponsorship of meetings. The Programme Committee for the Tenth Congress also met in Manchester, 2-4 July. This gave the Executive Committee the opportunity to discuss the plans for the Congress with Professor A. Vos, Chairman of the Programme Committee, and Dr H. M. Rietveld, Secretary and Treasurer of the Organizing Committee.

\section{Publications}

The period under review has seen great achievements in the Union's publishing programme. The Executive Committee has to devote much of its time to the finances and future plans for the publications.

The publication of its journals Acta Crystallographica and the Journal of Applied Crystallography is probably the activity for which the Union is best known. The publication 
of the annual indexes has been brought up to date and the cumulative index for Acta Cryst. for 1958-1967 was published early in 1975. In an effort to limit the necessary increase in subscription rates, the Executive Committee decided to limit the size of Section B of Acta Cryst. in 1974 and 1975 to about 2900 pages. This decision was made in accordance with the wishes to the Editor of the journal. Early volumes of Acta Cryst, and J. Appl. Cryst. were offered for sale at specially reduced prices in 1974 , but the response was disappointing.

In 1972, the total number of pages published in Acta Crystallographica (Volume 28) amounted to 4661, consisting of 985 pages in Section A (including 303 pages of abstracts communicated to the Ninth Congress) and 3676 pages in Section B, but excluding the 60-page joint index. In 1973 and 1974 the total numbers of pages were 3758 (Section A, 774; Section B, 2984) and 3812 (Section A, 874; Section B, 2983), respectively.

In 1972, the Journal of Applied Crystallography consisted of 448 pages, excluding indexes. In 1973 this rose to 502 pages and in 1974 to 638 pages. The substantial increase in 1974 is due to the publication of many papers presented at the Third International Conference on Small-Angle Scattering, held in Grenoble in September 1973. The April 1975 issue of the journal contained papers presented at the International Discussion Meeting on Studies of Lattice Distortions and Local Atomic Arrangements by X-ray, Neutron and Electron Diffraction, which was held in Jülich, B.R.D., 29 April-3 May 1974.

Structure Reports is rapidly being brought up to date. As a result of the increasing rate of publication of detailed crystal structure analyses, it became necessary, for Volume 30 onwards, to publish Structure Reports in two parts; A. Metals and Inorganic Compounds, and B. Organic Compounds (including organometallic compounds). Volume 29 (covering the literature for 1964) was published in 1972. Volumes $30 \mathrm{~B}, 31 \mathrm{~B}, 32 \mathrm{~B}, 33 \mathrm{~B}$ and $35 \mathrm{~B}$ were published in November 1974 and Volumes 28, 30A, 31 A, 33A and 35A in April 1975. Volume 35 deals with the literature for 1970. Hence, through tremendous efforts by a devoted team of crystallographers, many volumes of Structure Reports have been published in recent months. Work is being completed on the remaining volumes, and more volumes may be published before the Tenth Congress.

Volume IV of International Tables for X-ray Crystallography, entitled Revised and Supplementary Tables to Volumes II and III, was published in 1974. A second reprint of Volume II was published in 1972.

The bibliographic Volumes 4,5 and 6 , covering the references for organic and organometallic crystal structures published in 1972-74, and Volume Al (Interatomic Distances 1960-65) of the Molecular Structures and Dimensions series were also published. Finally, the Third Edition of the Index of Crystallographic Supplies was published and distributed free to all subscribers to the journals.

\section{The Commissions}

As mentioned during the Ninth General Assembly, the Executive Committee has undertaken a review of the work of all the Commissions of the Union and its Report to the Tenth General Assembly is given as Appendix E.

Each Commission Chairman is required to provide a written triennial report to the General Assembly. These Commission Reports, giving details of the work of the Commissions, are reproduced as Appendix C.
IUCr-IMA Joint Committee on Nomenclature

The report of this Committee is given as Appendix G.

Sub-committee on the Union Calendar

The report of this Sub-committee is given as Appendix $\mathrm{H}$.

\section{International Council of Scientific Unions (ICSU)}

The Union was represented at the ICSU General Assembly and associated General Committee meetings in 1972 and 1974, as well as the General Committee Meeting in 1973, by Professor A. Guinier. Dr J. N. King also represented the Union at the 1974 General Assembly. The Statutes and Rules of Procedure for ICSU were revised in 1972, with the result that the Executive Committee was renamed the General Committee and retained most of its predecessor's duties and responsibilities. A smaller committee, called the Executive Board, was established to direct the affairs of ICSU between General Assemblies and, as such, is required to meet at least twice a year.

The International Union of Pharmacology was admitted as a Scientific Union Member in 1972 and Lebanon and Sudan were admitted as National Members in 1974.

A number of cases had been reported to ICSU, when bona fide scientists from member countries of Unions had been prevented from attending symposia organized or sponsored by these Unions, through a refusal to grant entry visas. In the light of earlier ICSU resolutions emphasizing the right to free movement of scientists in this connexion, the General Assembly, meeting in 1974, drew the attention of Unions to the following guide lines and recommended their adoption:

1. Before symposia or meeting are arranged, an assurance in writing should be obtained from the organizers in the country concerned that visas will be granted to bona fide scientists if proper applications are made, and the unfortunate consequences which may arise through a failure to grant visas should be communicated to the organizers of the symposia or meetings involved.

2. The following procedure, recently adopted by IUPAC, was commended for observance by other Unions. Applications for visas where necessary should be made to the appropriate authorities not less than three months before the date of the symposium or meeting. If these visas are not granted or promised in writing one month before the date of the event, then sponsorship should be withdrawn.

3. National Members of ICSU should urge the authorities in their countries to facilitate attendance and exit visas for scientists to attend such meetings.

4. Each Union should inform ICSU and its Committee on the Free Circulation of Scientists of cases in which withdrawal of sponsorship has become necessary, so that other Unions may taken this into account in making their own future arrangements for symposia and meetings.

5. The Chairman of the ICSU Committee for Free Circulation and the ICSU Secretary General should maintain a record of cases reported, to which the Unions and other ICSU bodies may refer as may be necessary.

It was recommended that an appropriate institution in the People's Republic of China be again invited to become a member of ICSU. The wide interest and deep concern of participants at the General Assembly in the problems of developing countries was recognized. The Unions and National Members of ICSU were urged to encourage sup- 
port for efforts to solve the scientific and technical problems of developing countries, and to enlist the cooperation of scientists from the developing countries themselves.

The arrangements for the distribution of the annual UNESCO subvention to the Unions were changed in 1974, with the result that IUCr has been placed in the lowest category and will only receive $\$ 4000$ in 1975 . This matter has been taken up with ICSU by the Union's Treasurer.

The Union is represented on, and takes part in the work of, the ICSU Abstracting Board, the ICSU Committee on Data for Science and Technology and the ICSU Committee on the Teaching of Science. The triennial reports of these representatives, and representatives on other bodies not belonging to the Union, are given in Appendix F.

\section{Substitutions and Appointments}

The appointment of G. A. Jeffrey as a Co-editor of Acta Crystallographica, the re-appointment of J. M. Robertson and the appointment of N. G. Vannerberg as Coeditors of Structure Reports and the co-option of B. T. M. Willis and S. Hoshino as members of the Commission on Neutron Diffraction were approved by the Executive Committee in 1973. In 1974 R. D. Heidenreich resigned as a Co-editor of the Journal of Applied Crystallography and the Executive Committee approved the appointment of J. B. Cohen as a new Co-editor.

The ad interim Commission on Charge, Spin and Momentum Densities was created early in 1973 with the following membership: R. J. Weiss (Chairman), E. F. Bertaut, P. Cade, P. Coppens, Malcolm J. Cooper, B. Dawson, N. Kato, K. V. J. Kurki-Suonio, R. M. Moon, N. N. Sirota, E. F. Wölfel and L. M. Corliss (ex officio, as Chairman of the Commission on Neutron Diffraction). E. N. Maslen was appointed to the Commission in 1974 , following Dr Dawson's death.

\section{Union Staff}

The present staff in Chester is: Dr J. N. King (Executive Secretary), Miss K. M. Williams (Secretary); Mr S. A. Bryant (Technical Editor), Dr D. W. Penfold (Assistant Technical Editor), Dr J. E. Derry and Mr R. S. Daykin (Editorial Assistants), Mrs J. I. Heywood (Secretary). Mr Bryant will retire as Technical Editor at the end of 1975. Mr Daykin is leaving in August 1975, to take up another appointment.

\section{Acknowledgements}

On behalf of the Union, the Executive Committee wishes to express its deep gratitude to the Stichting voor Fundamenteel Onderzoek der Materie met Röntgen- en Elektronenstralen for the invitation to hold the Tenth General Assembly and International Congress of Crystallography in the Netherlands. Practically the whole of the country's crystallographic community has been involved in the preparation and organization of the Congress, and the Union is greatly indebted to everyone involved. The Executive Committee particularly wishes to express its appreciation for the work of the Chairman, Professor Dr D. G. Rieck, and the Secretary and Treasurer, Dr H. M. Rietveld, of the Organizing Committee, as well as to Professor A. Vos, Chairman of the Programme Committee.

The continuing interest and support shown by UNESCO, in the form of its annual subvention received by the Union through ICSU, is gratefully acknowledged.

Finally, the Executive Committee wishes to thank all those crystallographers who continue to spend so much time and energy in assisting in the work of the Union.

May 1975.

\section{Appendix B: Financial Report}

The accounts of the Union for the calendar years 1972 and 1973 have already been published [Acta Cryst. (1974). A30, 109-123 and 857-870]. The accounts for 1974 have been audited and will be published in Acta Crystallographica, Section A later in 1975 [Acta Cryst. (1975). A31, 870-875].

The accounts for the three years 1972,1973 and 1974 are summarized in Tables $1-9$, in which all amounts are expressed in U.S. dollars. The balance in each Fund Account at 31 December 1974 is given in Table 11. As a consequence of fluctuations in rates of exchange, a profit or a loss arose each year in terms of U.S. dollars. This profit or loss was divided amongst the Fund Accounts with credit balances, in direct proportion to the balances on these accounts at the end of the year in question. The fluctuations in exchange rates gave rise to a loss of $\$ 13996$ in 1972 , a profit of $\$ 31615$ in 1973 and a profit of $\$ 3796$ in 1974 , leading to an overall profit on fluctuations in exchange rates during the triennium of $\$ 21415$. The exchange rates in operation at 1 January 1972 were U.S. $\$ 1=$ Netherlands $f 3 \cdot 20=$ Danish Kr. 7.00 $=£ 0 \cdot 386=$ Swiss F 3.84. The exchange rates in operation at 31 December 1974 were U.S. $\$ 1=$ Netherlands $f 2 \cdot 60=$ Danish Kr. $5 \cdot 80=£ 0 \cdot 431=$ Swiss $\mathrm{F} 2 \cdot 74$

When the Acta Crystallographica accounts (Table 1), are examined, it should be remembered that the full annual combined subscription (for both sections) was D. Kr. 1000 in 1972, D. Kr. 1100 in 1973 and D. Kr. 1160 in 1974. The numbers of pages published in each section of the journal were as follows:

$\begin{array}{lrrr} & 1972 & 1973 & 1974 \\ \text { Section A } & 985 & 774 & 874 \\ \text { Section B } & 3676 & 2984 & 2938 \\ \text { Total } & 4661 & 3758 & 3812\end{array}$

Section A included 303 pages of Congress Abstracts in 1972. In an attempt to limit the increase in subscription rates, the Executive Committee restricted the size of Section $B$ to about 2900 pages for 1974 and for 1975. The numbers of subscribers to one or both sections of the journal were as follows:

$\begin{array}{lrrr} & 1972 & 1973 & 1974 \\ \text { Sections A and B } & 1891 & 1810 & 1796 \\ \text { Section A only } & 196 & 203 & 266 \\ \text { Section B only } & 114 & 116 & 177\end{array}$

The increase in the sales of back numbers is mainly the result of a special sale of early volumes of the journals, which was held in 1974. Publication costs have risen, the most significant increase being for the production costs in Denmark during 1974. The rate of inflation, which is the all-important factor in determining a realistic subscription rate, is now decreasing slightly in Denmark but inflation is still appreciable. Although there was an excess of income over expenditure for 1973 and for 1974 the balance in the fund account at the end of 1974 was only $51 \%$ of the estimated expenditure $(\$ 385000)$ for 1975 . At the end of the previous triennium (1971), the balance in the fund account was $58 \%$ of the expenditure for 1972 . 
The Journal of Applied Crystallography accounts are given in Table 2. The full subscription was raised from D. Kr. 240 to D. Kr. 300 for 1972 and remained unchanged for 1973 and 1974. The number of subscribers dropped from 1211 in 1972 to 1200 in 1973, but increased to 1221 in 1974 as a result of the special sale of Volumes $1-4$ to new subscribers. The numbers of pages published were 448 in 1972, 502 in 1973 and 638 in 1974 . The increase in size for 1974 is a result of the publication of many papers presented at the Third International Conference on Small-Angle Scattering, which was held at Grenoble in September 1973. These papers were published in the April 1974 issue of the journal. The deficit in 1974 confirmed the need for a further increase in the subscription rates, to D. Kr. 360, for 1975.
The Structure Reports accounts are shown in Table 3. Volume 27 was actually published in December 1971, but this was too late in the year for any publication expenses or sales income to appear in the 1971 accounts. Similarly, Volume 29 was published in December 1972 but the publication expenses and sales income appeared in the 1973 accounts. From Volume 30 onwards Structure Reports is being published in two parts: A. Metals and Inorganic Compounds, and B. Organic Compounds. Five B volumes (Volumes 30B, 31 B, 32B, 33B and 35B) were published late in 1974 , with the result that there were high publication costs and high sales income for that year. The sales income for 1974 was nearly equal to the total expenditure, this expenditure including appreciable payments for the pre-
Income

Subscriptions

Sale of back numbers and single copies

Airfreight charges to subscribers

Royalties

Less Publisher's commission

Yield from advertisements

\section{Expenditure}

Printing and binding

Distribution and postage

Airfreight costs

Indexes

Congress Supplement

Editorial expenses

Administration expenses

Difference between income and expenditure

Profit on fluctuations in rates of exchange

Accumulated balance at the end of the year
Table 1. Acta Crystallographica

\begin{tabular}{|c|c|c|c|c|c|}
\hline \multicolumn{2}{|c|}{1972} & \multicolumn{2}{|c|}{1973} & \multicolumn{2}{|c|}{1974} \\
\hline 245,356 & & 295,839 & & 339,054 & \\
\hline 15,797 & & 16,725 & & 21,979 & \\
\hline- & & 8,916 & & 9,034 & \\
\hline - & & - & & 13 & \\
\hline 261,153 & & 321,480 & & 370,080 & \\
\hline 32,644 & 228,509 & 39,070 & 282,410 & 38,889 & 331,191 \\
\hline & 6,082 & & 3,694 & & \\
\hline & 234,591 & & 286,104 & & 332,122 \\
\hline 180,660 & & 188,205 & & 221,456 & \\
\hline 14,485 & & 12,418 & & 12,501 & \\
\hline & & 8,031 & & 10,380 & \\
\hline 3,723 & & 3,433 & & 2,798 & \\
\hline $\begin{array}{r}4,345 \\
40,072\end{array}$ & & $\begin{array}{l}(1,075) \\
43.197\end{array}$ & & 49874 & \\
\hline 6,000 & 249,285 & 6,000 & 260,209 & 6,300 & 303,309 \\
\hline & $-\$ 14,694$ & & $+\$ 25,895$ & & $+\$ 28,813$ \\
\hline & $\frac{(3,020)}{\$ 126,009}$ & & $\frac{14,119}{\$ 166,023}$ & & $\frac{1,842}{\$ 196,678}$ \\
\hline
\end{tabular}

Table 2. Journal of Applied Crystallography

Income

Subscriptions

Sale of back numbers and single copies

Airfreight charges to subscribers

Royalties

Less Publisher's Commission

Yield from investments

\section{Expenditure}

Printing and binding

Distribution and postage

Airfreight costs

Indexes

Congress Supplement

Editorial expenses

Administration expenses

Difference between income and expenditure

Profit on fluctuations in rates of exchange

Accumulated balance at the end of the year

\begin{tabular}{|c|c|}
\hline \multicolumn{2}{|c|}{1972} \\
\hline $\begin{array}{r}45,793 \\
3,369\end{array}$ & \\
\hline - & \\
\hline$\frac{-}{49162}$ & \\
\hline $\begin{array}{r}49,162 \\
6,145\end{array}$ & \\
\hline 6,145 & 43,017 \\
\hline & 1,263 \\
\hline & 44,28 \\
\hline
\end{tabular}

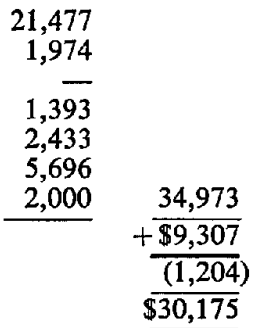

1973

51,813

2,508

1,683

56,004

6,790

49,214

$\frac{1,160}{50,374}$

27,408

1,617

1,661

554

(605)

6,709

2,000

39,344
$+\frac{\$ 11,030}{3,830}$
$\$ 45,035$
1974

54,949

4,073

1,745

4

$\overline{60,771}$

7,378

53,393

108

$\overline{53,501}$

40,586

2,198

2,076

1,015

7,990

2,100

55,965

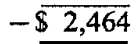

403

$\$ 42,974$ 
paration of manuscripts for volumes yet to be published. Although the accumulated balance at the end of 1974 is less than $\$ 18000$, the knowledge that many more volumes will be published in 1975 (Volumes 28, 30A, 31A, 33A and 35A were published in April 1975 and 5 more volumes are expected to be published by August) gives grounds for believing that this balance is not unsatisfactory. Most of the editorial and typing costs for the volumes to be published in 1975 had already been paid by the end of 1974 . The publication of so many volumes simultaneously appears to have put a considerable strain on many buyers, and many debts are as yet still outstanding.

The International Tables for X-ray Crystallography accounts are summarized in Table 4 . The major publishing cost was the publication of Volume IV in 1974. In addition, the binding costs for this volume, estimated to be about $\$ 6000$, will appear in the 1975 accounts. This volume became available in late 1974 with the result that not very many copies were sold before the end of the year. There is no system of standing orders, as there is for Structure Reports, which ensures the prompt sale of a large number of copies. It was also necessary to make a second reprint of Volume II in 1972, and to bind additional copies of all volumes. The expenses connected with the Pilot Issue were mainly printing costs in 1972 and the holding of a Commission meeting in 1973 , to assess the responses to the published Parts and to draw up a proposal for consideration by the Executive Committee in 1974 on the preparation and publication of new volumes of International Tables for Crystallography on symmetry tables. The work of D. S. Fokkema, in compiling suitable computer programs for calculation of the data for these new volumes and for automatic typesetting of this data, has continued during the triennium at a cost of $\$ 41126$. Finally, as part of the original plans for the Pilot Issue, 400 copies of the N.B.S. Monograph on Space Groups and Lattice Complexes were purchased.

The work on the new volumes of International Tables for Crystallography steadily depleted the accumulated balance until, at the end of 1974, the Fund Account had a deficit of $\$ 27968$. It is hoped that steady sales of the newly published Volume IV in the present series will provide an increased income in 1975 and 1976.

Tables 5 and 6 summarize the accounts for Fifty Years of X-ray Diffraction and Symmetry Aspects of $M . C$. Escher's Periodic Drawings. The former publication has continued to sell steadily, whilst the latter publication is now out of print. Negotiations have been in progress for

Table 3. Structure Reports

Income
Sale of copies
Less Publisher's commission
Expenditure
Printing and binding
Volume 27
Volume 29
Volumes $30 \mathrm{~B}-33 \mathrm{~B}$ and $35 \mathrm{~B}$
Binding additional copies of previous volumes
Typing of manuscripts
Editorial expenses
Difference between income and expenditure
Profit on fluctuations in rates of exchange
Accumulated balance at the end of the year

$40,254^{1972}$

$\begin{array}{r}7,104 \\ \hline\end{array}$

$\frac{24,594}{-}$
$\frac{1}{625}$
1,751
30,719
$-\frac{57,689}{\$ 24,539}$
$\frac{(2,175)}{\$ 54,501}$
1973

$$
41,430
$$$$
7,317
$$

34,113

103,381

18,131

1974

85,250

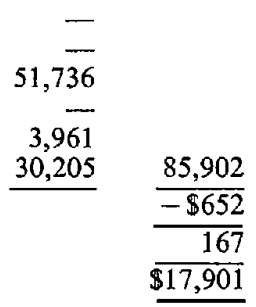

Table 4. International Tables for $X$-ray Crystallography

Income

Sale of copies

Less Publisher's commission

Sales of N.B.S. Monograph

\section{Expenditure}

Printing and binding reprint of Volume II

Printing of Volume IV

Binding additional copies

Editorial expenses

Pilot Issue

Computer Trial Project

N.B.S. Monograph

Difference between income and expenditure

Profit on fluctuations in rates of exchange

Accumulated balance at the end of the year
1972

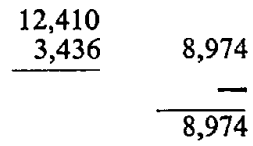

6,080

$\overline{999}$

453

3,118

6,842

$\frac{\frac{17,492}{-\$ 8,518}}{\frac{(1,289)}{\$ 32,299}}$
1973

11,133

3,036

8,097

12,517

1974

-
6,061
$5, \overline{196}$
5,196
6,299
17,940

$\stackrel{-\frac{36,409}{\$ 28,312}}{\frac{\$ 371}{\$ 4,358}}$
3,585 
some time for the publication of a paperback edition of Symmetry Aspects of $M$. C. Escher's Periodic Drawings.

The Early Papers on Diffraction of $X$-rays by Crystals accounts are shown in Table 7 . Volume I was published in 1969 and Volume II in 1972, with the aid of an UNESCO subvention of $\$ 3500$ for the preparation of the manuscript. Sales dropped appreciably in 1973 and 1974, and the account still had a deficit of $\$ 8964$ at the end of 1974 .

Annual volumes in the bibliographic series on organic and organometallic crystal structures, Molecular Structures

Table 5. Fifty Years of X-ray Diffraction

Income

Sales of copies

Less Publisher's commission

Difference between income and expenditure

Profit on fluctuations in rates of exchange

Accumulated balance at the end of the year

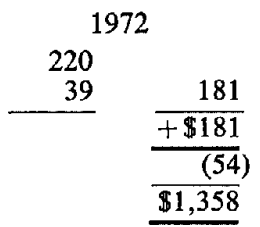

1974

176

$\frac{\frac{185}{+\$ 185}}{\frac{143}{\$ 1,686}}$

$\begin{array}{r}\frac{145}{+\$ 145} \\ \frac{17}{\$ 1,848} \\ \hline\end{array}$

Table 6. Symmetry Aspects of M. C. Escher's Periodic Drawings

Income

Sale of copies

Less Publisher's commission Royalties

Difference between income and expenditure Profit on fluctuations in rates of exchange Accumulated balance at the end of the year
1972

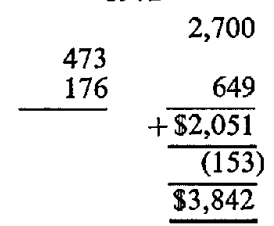

1973

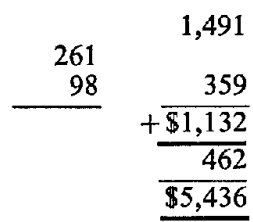

1974

\begin{tabular}{rr}
62 & 357 \\
23 & $\frac{85}{+\$ 272}$ \\
\hline & $\frac{54}{\$ 5,762}$ \\
\hline
\end{tabular}

Table 7. Early Papers on Diffraction of X-rays by Crystals

Income

Sale of copies

Less Publisher's commission

\section{Expenditure}

Printing and binding Volume II

Binding copies of Volume I

Editorial expenses

Difference between income and expenditure

Profit on fluctuations in rates of exchange

Accumulated balance at the end of the year

\begin{tabular}{ccc}
1972 & 1973 \\
4,865 & & 2,263 \\
851 & 4,014 & 396 \\
\hline
\end{tabular}

1,867

13,761

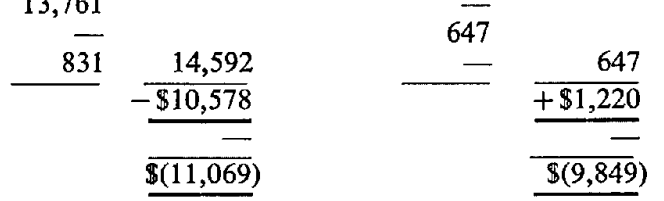

1974

1,073

188

885

Table 8. Molecular Structures and Dimensions

Income

Sale of copies

Less Publisher's commission

\section{Expenditure}

Printing and binding

Volume 3

Volume 4

Volume 5

Volume A 1

Carriage, advertising and other expenses Administration expenses

Difference between income and expenditure

Excess of income over expenditure paid to University of Cambridge

Profit on fluctuations in rates of exchange

Accumulated balance at the end of the year

\begin{tabular}{|c|c|c|c|c|c|}
\hline \multicolumn{2}{|c|}{1972} & \multicolumn{2}{|c|}{1973} & \multicolumn{2}{|c|}{1974} \\
\hline 12,522 & 10331 & 44,198 & 36.647 & 21,353 & 17616 \\
\hline & & & & & \\
\hline 3,795 & & - & & - & \\
\hline 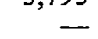 & & 3,235 & & - & \\
\hline - & & - & & 4,346 & \\
\hline - & & 12,978 & & - & \\
\hline 250 & & 3,187 & & 256 & \\
\hline 475 & 4,520 & 595 & 19,995 & 645 & 5,247 \\
\hline & $+\$ 5,811$ & & $+\$ \overline{16,652}$ & & 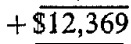 \\
\hline & 5,520 & & 15,820 & & 11,751 \\
\hline & $\frac{(36)}{\$ 922}$ & & $\frac{163}{\$ 1,917}$ & & $\frac{24}{\$ 2,559}$ \\
\hline
\end{tabular}


and Dimensions, were published in 1972, 1973 and 1974. In addition, Volume A1 Interatomic Distances 1960-65 was published in 1973. Although income far exceeded publication costs, $95 \%$ of this excess was paid back to the University of Cambridge to offset the expenses incurred by the Crystallographic Data Centre. The Union received $5 \%$ of the net excess of income over expenditure, which increased the accumulated balance by $\$ 1637$ to $\$ 2559$ (Table 8).

Table 9 summarizes the accounts for the General Fund

Table 9. General Fund

\section{Income}

Subscriptions from Adhering Bodies

Yield from investments and bank accounts

Grant received from UNESCO subvention to ICSU

Refund of previous year's subscription to ICSU

Sale of copies of: World Directory of Crystallographers Incidental publications

Amount charged to Journals and Publications: Acta Crystallographica

Journal of Applied Crystallography

Molecular Structures and Dimensions

\section{Expenditure}

Administration

Subscriptions to ICSU and bodies of ICSU

Executive Committee Meeting

9th General Assembly and Congress:

Publication of Report

Executive Committee

Travel Grants

Programme Committee

Expenses of Commissions

10th General Assembly and Congress:

Programme Committee

IUCr representatives on other bodies - trave] expenses

Commissions' expenses

Sponsorship of meetings

Index of Crystallographic Supplies; net cost

Difference between income and expenditure

Profit on fluctuations in rates of exchange

Accumulated balance at the end of the year
1972

13,200

21,487

6,250

240

2,742

219

6,000

2,000

240

52,378

25,779

662

-

$9,5 \overline{57}$

10,648

31

348

5

$\begin{array}{r}383 \\ 1,293 \\ \hline\end{array}$

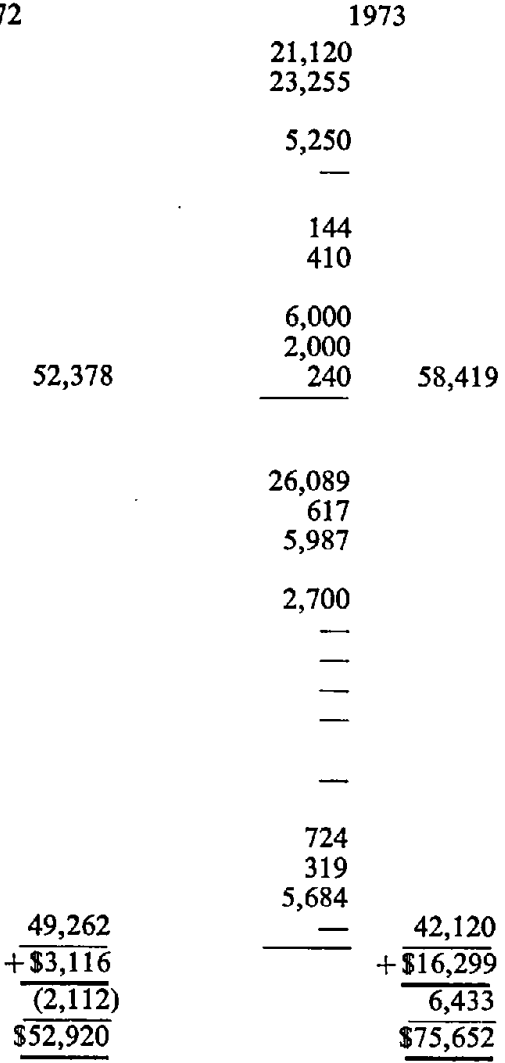

1974

21,120

22,533

5,250

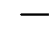

100

215

6,300

2,100

$240 \quad 57,858$

27,972

814

7,504
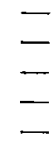

2,319

1,205

3,492

7,214

50,520

$+\$ 7,338$

$\frac{785}{\$ 83,775}$

Table 10. Comparison of budget and accounts for the years 1972-1974 inclusive

\section{Income}

Subscriptions from Adhering Bodies

Yield from investments and banking accounts 55,440

Subventions from UNESCO through

Sale of incidental publications and

World Directory of Crystallographers

Profit on fluctuations in rates of exchange

\section{Expenditure}

Administration

Subscriptions to ICSU and bodies of ICSU

Administrative meetings

Scientific meetings

Cost of incidental publications

Favourable variant from budget

Less Budgeted deficit

Excess of income over expenditure
Budget

16,750

2,310

129,500

54,000

2,000

29,000

44,000

4,000

133,000
Accounts

55,440

67,275

16,750

3,830

5,106

148,401

54,720

1,853

28,238
30,438

1,293
Difference
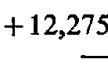

$+1,520$

$+5,106+18,901$

$+720$

$-147$

$-762$

$-13,562$

$-2,707 \quad-16,458$

116,542 
Table 11. Balance Sheet, Fund Accounts

Acta Crystallographica

Journal of Applied Crystallography

Structure Reports

International Tables

Fifty Years of $X$-ray Diffraction

Escher Drawings

Early Papers

Molecular Structures and Dimensions

General Publications

Total of publication accounts

General Fund

Total accumulated balance
Profit on fluctuations in rates of

31 December 1971

145,731

22,072

81,215

42,106

1,231

1,944

(491)

667

50,688

$\$ 345,163$

51,916

$\$ \overline{\$ 397,079}$ exchange

10,933

3,029

(444)

(918)

106

363

$\overline{151}$

3,089

$\$ 16,309$

5,106
31 December 1974

196,678

42,974

17,901

$(27,968)$

1,848

5,762

$(8,964)$

2,559

53,777

$\$ 284,567$

83,775

$\overline{\$ 368,342}$
Table 12. Balance Sheet, Assets

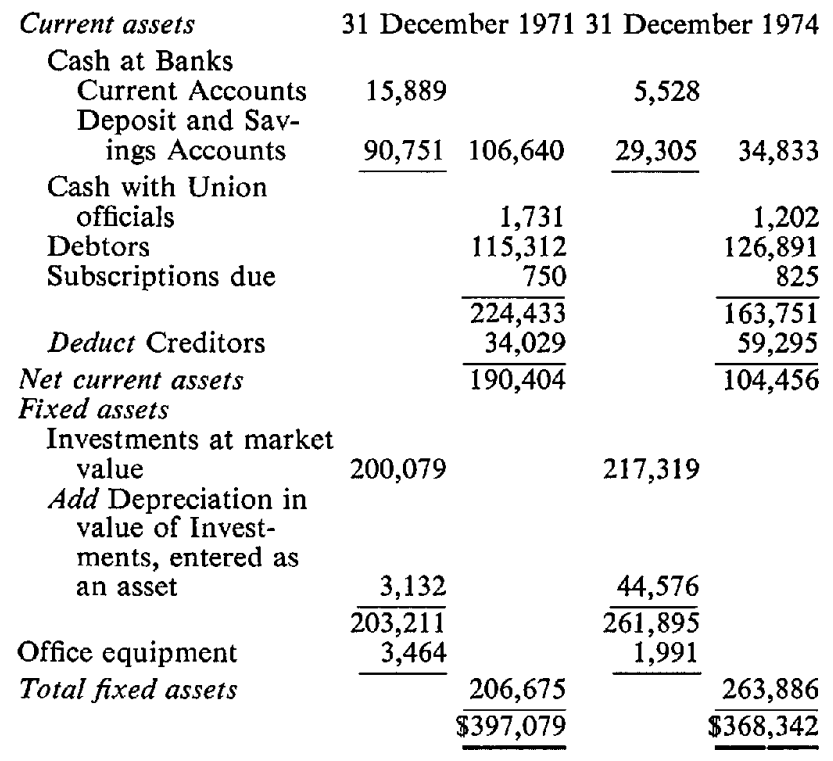

of the Union, while Table 10 compares the accounts for the triennium with the budget approved by the Ninth General Assembly. Table 10 shows a favourable variant of $\$ 35359$ from the budget, including a profit of $\$ 5106$ on fluctuations in rates of exchange over the triennium. Allowing for the budget deficit of $\$ 3500$, the actual excess of income over expenditure for the General Fund was $\$ 31859$. The yield from investiments was $\$ 12275$ more than was budgeted for. Since nearly $70 \%$ of the Union's investments are held in currencies other than U.S. dollars, when expressed in dollars the yield from investments is very prone to influence by fluctuations in exchange rates. The administrative expenses of the Union increased slightly, but were only $\$ 720$ more than the budgeted amount. Travel and accommodation costs increased appreciably, and this affected the expenses of the Executive Committee meetings and the Union representatives on other bodies. Appreciably less than estimated was spent on scientific meetings, including meetings of Commissions. Only two Commissions decided to hold meetings-in-person. The Commission on Crystallographic Apparatus and the ad interim Commission on Charge, Spin and Momentum Densities met in 1974, on the occasion of relevant conferences.

Tables 11 and 12 give a comparison of the Balance Sheet of the Union at the beginning and the end of the triennium. Table 11 shows the fund accounts, whilst Table 12 shows the distribution of the assets. Not only have the total assets dropped from $\$ 397079$ to $\$ 368342$ during the period, but these figures include allowance for the profit of $\$ 21415$ on fluctuations in rates of exchange. For the publication accounts the drop in assets is even more striking, from $\$ 345163$ to $\$ 284567$, including a profit of $\$ 16309$ on fluctuations in rates of exchange. Although the stocks of Volumes 1-27 of Acta Crystallographica have been reduced substantially, because they were far larger than necessary, it should be remembered that the stocks of unsold copies of the other volumes of that journal and of the other publications of the Union have increased. The value of these stocks is not included in the assets and it represents a substantial asset which is continuously being converted into cash.

Although the balances in the journals' accounts have increased, so have production costs, and the balances at 31 December 1974 are substantially less than the annual expenditure on printing and editing. The low balance at present in the Structure Reports account is the result of intensive editorial work on many volumes simultaneously. This balance should improve rapidly with the publication of many volumes in 1975 , bringing Structure Reports up to date. The negative balance in the International Tables account at the end of 1974 gives more cause for concern. Although it is partly the result of reprinting Volume II and publishing Volume IV, and good sales of the latter volume are expected in 1975, the major expenses in recent years have been on the Pilot Issue and the associated Computer Trial Project. These expenses must now be considered a part of the production costs of the new symmetry tables.

The assets at 31 December 1974, as shown in Table 12, include an amount of $\$ 126891$ for debtors. The largest part of this relates to amounts due at that date in respect of the publishing operations during 1974, including $\$ 57896$ from Messrs Munksgaard, in connexion with Acta Crystallographica and the Journal of Applied Crystallography, and $\$ 52636$ from Messrs Oosthoek, Scheltema and 
Holkema, in connexion with Structure Reports. These amounts, due in 1975, and the great majority of the other amounts under debtors and creditors have since been settled.

The Union's bank accounts are held with the Union Bank of Switzerland in Geneva, the Amsterdam-Rotterdam Bank N.V. in Groningen, the First National City Bank in New York and the National Westminster Bank in Manchester and Chester. The investments are in government bonds due to mature at various dates until 1993 and with a total maturity value of Swiss Fr. 18000 , plus Netherlands $f 277000$, plus U.S. $\$ 86500$, plus $£ 30000$. The largest single holding at 31 December 1974 was of $£ 300008 \frac{1}{4} \%$ U.K. Treasury Loan 1987/90.

As an association incorporated in Switzerland, the Union is exempt from Swiss Federal and Genova Cantonal Tax. Under the terms of the United Kingdom/Switzerland Double Taxation Agreement 1967, whilst present circumstances obtain, all income arising within the United Kingdom is not subject to United Kingdom tax.

\section{Appendix C: Reports of the Commissions of the Union}

\section{(a) Commission on Journals}

During the triennium the Commission on Journals produced Volumes 28 to 30 of Acta Crystallographica and Volumes 5 to 7 of the Journal of Applied Crystallography. Full statistical analyses have been published in the annual reports of the Executive Committee. In 1971 the staff of the Technical Editor's office was enlarged, and the printers moved to larger premises, so that the rate of publication of the journals could be accelerated. During 1972 the backlog of unpublished papers was entirely cleared, and there has been a gratifying reduction in the time required for publication. The number of papers submitted for publication continues to increase, and this is reflected in an increase in the number of pages in Section A of Acta Crystallographica and in the Journal of Applied Crystallography. In order to keep costs within reason, however, the Executive Committee has limited the size of Section of Acta Crystallographica to approximately 2900 pages per year. By encouraging authors to compress their style and to make greater use of the section Short Structural Papers (introduced in 1972), the Editors have been able to avoid any consequent substantial increase in publication times in Section B, though a few papers which might otherwise have appeared in December 1974 were held over until January 1975. Delivery time to subscribers in the United States and Canada has been reduced by shipment by air freight. This involves a small surchange for subscribers in these countries, but the quicker delivery of the journals has been generally welcomed.

The second cumulative decennial index to Acta Crystallographica (Volumes 11-23, 1958-1967, pp. ii +146) has now been published. All issues of the journal that appeared before the division into Sections A and B in 1968 can now be searched via only two indexes. The second index is considerably larger than the first (pp. 57), and it is planned to issue the cumulative indexes on a quinquennial basis in future.

The Commission is still concerned about the time interval required for publication by current methods, and about the high cost of, in particular, Section B. It has, therefore, set up two working groups, on production methods and on publication of structures respectively, to consider other methods of publication and to make recommendations to the Commission and the Executive Committee if any changes appear to be advantageous. The The printers have installed equipment for optical 'typesetting', and it is expected that this will begin to be used, on an experimental basis, for the Journal of Applied Crystallography in the course of 1975.

A new set of Notes for Authors was approved by the Commission in the course of its meetings in Kyoto in 1972, and was published in the first 1973 issue of each Journal. A new set of Notes for Referees has also been prepared.

The Institute for Scientific Information, which publishes the Science Citation Index, has made a number of studies of the citation of papers and journals. Those published in the issues of Current Contents for 6 March and 11 September 1974 are of particular interest to crystallographers. The first study lists the hundred 'chemical' articles most frequently cited by authors in 'chemical' (excluding biochemical) journals in the cause of 1972. The order is:

$\begin{array}{ll}\text { Journal of Chemical Physics } & (22 \%) \\ \text { Journal of the American Chemical Society } & (19 \%) \\ \text { Acta Crystallographica } & (15 \%) \text {. }\end{array}$

No other journal accounted for more than $6 \%$. Since Acta Crystallographica is by no means outstanding by number of pages, it would seem that it publishes a higher proportion of 'significant' papers than most journals do. Its position in the 'physics' citation order is not as well established. The data are older (1969) and analysed in a different fashion; its rank varies from tenth to seventeenth, depending on the criterion adopted (Physics Today, May 1974, pp. 40-41; Current Contents, 2 October 1974).
21 April 1975.
A. J. C. WILson, Chairman R. A. Young, Co-Chairman

\section{(b) Commission on Structure Reports}

In 1972 a new general editor was appointed and the two general editors have been supervising an effort to complete and publish volumes for recent years while filling in the backlog of missing volumes. This has involved a three-year period of hectic work by general editors, co-editors, reporters, publisher and printer, and the resulting progress has exceeded the hopes of even the most optimistic of those involved. Volume 29 (for 1964) was published in 1972 and Volumes 30B, 31B, 32B, 33B and 35B (Organic Compounds for 1965, 1966, 1967, 1968 and 1970) in November 1974, whilst Volume 28 (for 1963) and Volumes 30A, 31 A, $33 \mathrm{~A}$ and 35A (Metals and Inorganic Compounds for 1965 , 1966, 1968 and 1970) were published in April 1975. All other volumes, up to an including Volume 39 (for 1973), are now with the printer and most of these volumes should appear later in 1975. The ten-year index for 1961-70 is in preparation.

From Volume 30 onwards the volumes have been produced by photo-offset reproduction of typed manuscripts. This had led to a very considerable decrease in the cost of the volumes, in spite of generally increasing costs of production.

The general editor has participated in the Working Party on Information Services, whose report should enable decisions to be made on the future of Structure Reports.
28 April 1975.
I. Trotter, Chairman 


\section{(c) Commission on International Tables}

\section{Present edition}

Volume IV of the present edition, entitled Revised and Supplementary Tables to Volume II and III, xii + 366 pages, was published in October 1974. This volume was edited by J. A. Ibers and the late W. C. Hamilton.

The present edition (Volumes I to IV) continues to sell well, as can be seen from Table I.

\section{Pilot Issue for Series A: Symmetry Tables}

Part 1 (Direct Space) and Part 2 (Reciprocal Space) of the Pilot Issue were published just before the Ninth Congress, held in Kyoto in 1972. Part 3 (Patterson Data) was published in 1969. Part 4 (Synoptic Tables) was published and distributed in March 1973. The original plans for a revised Part 5 (Generalized Symmetry) and a Part 6 (Physical Properties in Symmetric Media) were abandoned. The Commission has proposed that, instead of publishing Part 6 , a series of monographs on selected topics in crystallography might be published, stressing primarily the relations between physics and crystallography.

In connexion with the Pilot Issue, but published separately, National Bureau of Standards Monograph No. 134 appeared in May 1973. It was prepared by W. Fischer, H. Burzlaff, E. Hellner and J. D. H. Donnay, and entitled Space-groups and Lattice Complexes.

Work on the English translation of the introduction to the book by V. A. Koptsik, Shubnikov Groups, published in Moscow in 1966, is being continued by N. F. M. Henry.

\section{New Edition of International Tables}

From 30 August to 3 September 1973 the Commission held a meeting at St. Nizier, near Grenoble, France, at the kind invitation of Dr E. F. Bertaut. The major points on the agenda were as follows:

(a) evaluation of the Pilot Issue and responses to it. (There were a fair number of responses, many of them quite detailed and helpful.)

(b) discussion of and decision on the new edition of International Tables for Crystallography;

(c) proposal for the budget, the time-table and the publication of the new edition;

(d) future activities of the Commission.

The Commission unanimously agreed on a proposal for the new edition. The plans include the publication of three volumes, the furst containing text and synoptic material, the second containing tables for direct space and the third containing tables for reciprocal space. The data for the tables will be obtained from computer programs and will be printed by computer typesetting. This task will be performed by D. S. Fokkema.

At the meeting of the Executive Committee of the Union at Manchester, in July 1974, the proposal of the Commission was accepted in principle. Specifically, the production of the second volume of the new edition, Tables for Direct Space, was authorized.

The programs both for calculations and computer typesetting are being produced and executed by D. S. Fokkema at Groningen in close contact with the Chairman of the Commission. All programs for the generation of the data for the new volume on direct space are finished. These programs have now been tested on all space groups and no serious errors have been detected.

A program system has been prepared to provide automatic photo-typesetting of the data. With the help of these programs a magnetic tape is prepared which contains all instruction codes for controlling a photo-typesetting machine. These typesetting routines have been tested for all the kinds of data to be included; results are satisfactory but many changes may still be necessary in order to obtain an acceptable page layout. A production and storage system has been devised, to provide easy handling of the great amounts of data involved in the preparation of the new volume. Work on the new diagrams for each space group is in progress.

It is intended to have a draft of the computer-produced data for some space groups available at the Tenth Congress in Amsterdam for inspection by the crystallographic audience.

30 April 1975.

TH. HaHN, Chairman

\section{(d) Commission on Crystal Growth}

The Commission met during the Fourth International Conference on Crystal Growth (ICCG-4), at Tokyo in March 1974. Several members were also able to meet at Tsakhkadzor (USSR) in September 1972.

One of the main points of discussion was the position of the Commission with respect to the International Organization for Crystal Growth (IOCG). As it seems that the IOCG does not create commissions for certain purposes, there is still a task for the $\mathrm{IUCr}$ Commission regarding the purely crystallographic aspects of crystal growth (morphology, surface structure, defect structure and relation of growth to crystal structure), and regarding organization, standardization and registration.

Several members of the Commission were heavily involved in the work for ICCG-4, held at Tokyo, 24-29 March 1974 and in the Second International Spring School on Crystal Growth (ISSCG-2), held at Lake Kawaguchi, 31 March-7 April 1974. Both meetings were co-sponsored by the IUCr and both were quite a success, not only in the scientific, but also in the organizational aspects. Future activities in which the Commission is involved are:

Third International Conference on Vapour Growth and

Table I. Sales of International Tables

$\begin{array}{lcrrr}\text { Volume } & \text { I } & \text { II } & \text { III } & \text { IV } \\ \text { Date of publication } & 1952 & 1959 & 1962 & 1974 \\ \text { Dates of reprinting } & 1965,1969 & 1967,1972 & 1968 & - \\ \text { Number of copies sold up to 31 December 1974 } & 8000 & 7080 & 6280 & 459 \\ \text { Number of copies sold between 1 July 1972 and 31 December } 1974 & 796 & 606 & 627 & 459 \\ \text { Stock at 31 December 1974 } & 474 & 1516 & 1255 & 3541\end{array}$


Epitaxy, Amsterdam, The Netherlands, 18-21 August 1975; International Summer School on X-ray Dynamical Theory and Topography, Limoges, France, 18-26 August 1975 ;

Course on Crystal Growth, Erice, Sicily, Italy, 30 August -7 September 1975;

Third International Summer School on Crystal Growth Durham, New Hampshire U.S.A. 10-15 July 1977;

Fifth International Conference on Crystal Growth, Boston, Massachusetts, U.S.A., 17-22 July 1977.

Other activities are: (1) a project about a proposal for a convention notation for absolute structures and their relation to etching behaviour and piezoelectric proporties (unfortunately this project could not be finished); (2) a compilation of films on crystal growth; (3) a standardization of symbols for use in crystal growth research. The latter two projects have just started, and cooperation with other bodies and individuals is necessary and solicited.

7 May 1975.

P. HARTMAN, Chairman

\section{(e) Commission on Crystallographic Apparatus}

The Commission met in Kyoto, following the close of the Ninth General Assembly and Congress, and again in Madrid, Spain, 18-19 April 1974, prior to the Inter-Congress Conference on Anomalous Scattering. All remaining matters were dealt with by correspondence. S. Abrahamsson (Sweden), M. Font-Altaba (Spain), R. W. Hendricks (U.S.A.), L. D. Jennings (U.S.A.) and H. van Koningsveld (Netherlands) were elected Consultants to the Commission.

The work of the Commission from 1972 to 1975 may broadly be divided into the organization of experimental and other projects, the arrangement of meetings, and publications as follows.

\section{Projects}

1. Small-Angle Scattering Absolute Intensity Project (R. W. Hendricks)

Absolute intensity measurements on standard samples of glassy carbon and polystyrene have been received from seven laboratories in six countries. Computer processing of the extensive raw data is complete and a statistical intercomparison of the results is in progress. A preliminary report was given at the Third International Small-Angle Scattering Conference in Grenoble, France, in September 1973, and a final report will be presented at an Open Meeting at the Tenth Congress.

2. Powder Intensity Project (P. Suortti and L. D. Jennings) Measurements on a nickel standard sample are nearly complete, and an analysis of the result, together with a critical appraisal of the measurement procedures used in accurate powder intensity determination, is being prepared for presentation at the Congress and subsequent publication.

3. Single-Crystal Radiation Damage Project - Phase II (R. Rudman and S. C. Abrahams)

The results of Phase I of this project, which appeared in Acta Cryst. (1973). A29, 111-116, showed that radiationinduced intensity changes may occur in crystals of widely different composition, and need be neither monotonic with exposure, nor uniform over all reflections. Phase II, con- sisting of a systematic study of three laboratories over a period of about two years on the effects of radiation damage on single-crystal intensities, can be completed only by the expenditure of a substantial research effort. Funding by sources such as the U.S. National Science Foundation may be accomplished best by direct support of individual investigators selected by the Commission. Three crystallographers have now been selected and have submitted informal research proposals that will be coordinated before the Tenth Congress into a single request for specific support.

\section{Accuracy of Intensities Determined Microdensitome-} trically (S. Abrahamsson)

The importance and growing use of microdensitometers for measuring integrated intensities had led to the recent activation of this project. Detailed organizational procedures for the project are being drawn up by S. Abrahamsson, with G. Lundgren and P. Kierkegaard as co-organizers, preparatory to inviting the participation of many laboratories. Presentation and discussion of these procedures is expected at the Tenth Congress.

\section{Radiation Safety (R. Rudman and M. Colapietro)}

A survey of recommended radiation safety procedures, detectors, calibration, and related matters is being undertaken in response to the increasing development of legal standards and regulations in this area.

\section{Nomenclature Standardization in Small-Angle Scattering} (R. W. Hendricks)

An international ad hoc Committee has been appointed by the Commission, to consider inconsistencies in current nomenclature, especially between varying notations used in large-angle and small-angle scattering. A preliminary report will be given at an Open Commission Meeting at the Tenth Congress.

\section{Single-Crystal Intensity Measurement Project - Phase II} (A. McL. Mathieson)

A preliminary report was presented at an Open Commission Meeting at the Ninth Congress. Preparation of the final report has been delayed, but is expected to be complete in 1975.

8. Congress Exhibitions of Non-Commercial Equipment and Visual Aspects of Crystallography (H. van Koningsveld and R. Rudman)

Notices concerning these exhibitions have appeared in Acta Cryst. (1975). B31, 333 and in the Tenth Congress General Information Brochure.

\section{Other Projects}

Additional projects discussed, but on which no action was taken in this period, included consideration of the accuracy of thermal diffuse scattering measurements; the accuracy with which intensity measurements can be made using solid-state and position-sensitive detectors; the advantages and difficulties associated with synchrotron radiation sources; and the possibility of formulating a new set of high-precision tolerances for goniometer heads.

\section{Meetings \\ Inter-Congress Conference on Anomalous Scattering}

The Conference was held 22-26 April 1974 in Madrid, 
Spain, with S. Ramaseshan, Program Chairman; M. Font-Altaba, Local Chairman; and S. C. Abrahams, Chairman. A total of 33 papers were presented on the following eight major areas: theoretical calculation of dispersion corrections; experimental determination of dispersion corrections; novel applications of anomalous scattering; absolute configuration and tensorial properties; accurate intensity measurement; effects of dispersion on atomic parameters; use of anomalous scattering in protein structure analysis; structure determination using neutron anomalous scattering. Eighty-seven scientists from 19 countries participated, with 13 accompanying members. The provision of meeting space and a generous subvention by the Consejo Superior de Investigaciones Cientificas is gratefully acknowledged.

\section{Open Commission Meetings at the Tenth Congress}

(a) 'Novel Crystallographic Measurements by Use of SolidState and Position-Sensitive Detectors' (S. Hosoya and R. W. Hendricks)

(b) 'Small-Angle Scattering Measurements by X-ray and Neutron Diffraction' (R. W. Hendricks)

(c) 'Extinction Corrections, Theory and Experimental Measurement', organized jointly with the ad interim Commission on Charge, Spin and Momentum Densities (R. J. Weiss, P. Suortti and S. C. Abrahams)

(d) 'Single Crystal Diffraction Measurements at Controlled Pressures and Temperatures: Present Status and Future Trends', organized jointly with the Commission on Crystallographic Studies at Controlled Pressures and Temperatures (M. Foex and S. C. Abrahams)

\section{Publications \\ Anomalous Scattering}

This book is the Proceedings of the Madrid Conference mentioned above, and is edited by S. Ramaseshan and S. C. Abrahams. Each major area of the conference forms a chapter in the book. Referees, drawn from the participants, were assigned to each paper. Discussion leaders were appointed and they were responsible for providing a narrative account of each discussion. The 550 page book is due to published by Munksgaard in May 1975, at a price of 200 Danish Kroner.

8 April 1975.

S. C. Abrahams, Chairman

\section{(f) Commission on Crystallographic Computing}

There has been no formal meeting of the Commission since the Ninth Congress at Kyoto in 1972. At that meeting the Commission agreed to pursue four areas of activity; the following is a review of the progress in these areas.

\section{Additional standard tests}

The outline for Part II of the Standard Tests has been decided. This part will deal with the structure determination, and geometrical calculations of actual crystal structure in different symmetries. Professor J. M. Stewart started work on the first round of calculations, but little work was done on the project in 1974. The Commission hopes to complete these preliminary calculations before the Tenth Congress.
2. Supplement to the World List of Crystallographic Computer Programs

The third edition of the World List was published in J. Appl. Cryst. (1973). 4, 309-346. In order to update this list, it was decided to prepare a yearly supplement, and this was announced in Acta Cryst. (1974). A 30, 303. The response to this announcement was insufficient to justify publication of a supplement at this time.

\section{The 1975 International Summer School on Crystallo- graphic Computing}

The major effort of the Commission has been concentrated on planning and organizing a summer school to be held in Prague, Czechoslovakia, 28 July-5 August 1975. Planning has gone ahead on schedule, and all indications are that this school will prove to be a very worthwhile scientific undertaking. Direct methods of structure solving and the computational aspects of protein crystallography will be emphasized; the remainder of the programme will cover miscellaneous crystallographic computer applications and techniques. The Director of the Institute of Macromolecular Chemistry of the Czechoslovak Academy of Sciences will act as Host to the School, and Dr K. Huml of the same Institute is Chairman of the Local Organizing Committee. The teaching staff will consist of 34 invited lecturers and 15 invited contributors, and the total number of school participants will easily exceed 200. Six of the participants will be partially supported by a UNESCO travel grant. Munksgaard has agreed to publish the proceedings of this school in book form.

\section{Communication within the Commission}

The decision that each member should distribute a yearly informative letter to the other members and consultants of the Commission has not been implemented satisfactorily thus far. However, all the members and consultants have responded promptly to the Chairman's circulars, but this has not been sufficient to improve the communication among the members.

Professor M. M. Woolfson has proposed and undertaken the setting up of a Bank of Trial Structures for testing direct methods. An announcement of this project was published in Acta Cryst. (1974). A 30, 303.

Throughout the period of this report, the Chairman has participated in the discussions of the IUCr Working Party on Information Services.

\section{General Comment}

There is no doubt that the activities of this Commission have been curtailed somewhat by the present world economic situation and the reduced level of support to scientific research in most countries.
9 April 1975.
F. R. AHMED, Chairman

\section{(g) Commission on Crystallographic Data}

At the Ninth International Congress two closed business sessions were held and two Open Commission Meetings - one on powder data, the other on data storage, search, retrieval and publication. The latter was organized jointly with the Commissions on Crystallographic Computing, Journals and Structure Reports.

The Commission discussed standards of publication of data in non-Union journals and it was suggested that an 
appropriate check list be circulated to editors of various journals which publish crystallographic data. Particular concern was expressed on the growing practice of depositing atomic coordinates and it was agreed that this should be discouraged.

In view of the proliferation of data services and compendia it was decided that a list of such items be prepared and submitted for publication by the Union and the ICSU Committee on Data for Science and Technology (CODATA). This problem was recognized at the Ninth General Assembly of the Union, when a Working Party on Information Services was established. The Commission has been urged to communicate its views to this group. The Chairman has met with H. M. Ondik and G. G. Johnson Jr on two separate occasions and discussed further details of the proposed list of crystallographic information services. A summary list has been prepared and circulated to all members, for additional contributions prior to the final version being drafted.

The Commission agreed at the Ninth International Congress to give advice, if needed, to the group responsible for the preparation of the next edition of the World Directory of Crystallographers. Early in 1973 the Chairman sent to H. Cole and S. C. Abrahams detailed suggestions on the file structure of the machine-readable data base together with some comments on production costs in the U.K.

There has been correspondence with the Chairman of the Commission on Crystallographic Computing with respect to the summer school on computing to be held in August 1975. It was suggested that it might be appropriate to incorporate in the programme some lectures on information retrieval and this has been arranged.

A document has been submitted by I. D. Brown describing a 'standard' computer file format for the storage of inorganic structural data. This document has been circulated to establish whether the Commission should study this project in detail with a view to preparing a report for publication.

Discussions have taken place, by correspondence, with the Chairmen of the Commissions on Journals, Crystallographic Computing, Structure Reports and International Tables and the Chairman of the Working Party on Information Services, with a view to holding an Open Meeting during the Tenth International Congress in Amsterdam. It has been decided to hold an Open Meeting, entitled 'Crystallographic Information Services', with invited speakers and the programme is now complete. An Open Commission Meeting has been arranged on 'Powder Data'.

\section{April 1975.}

\section{G. WATSON, Chairman}

\section{(h) Commission on Crystallographic Nomenclature}

The Commission has not been able to meet during the triennium, though some members had informal discussions during the Kyoto Congress in 1972 . In 1973 the Chairman attended those sessions of the meeting of the Commission on International Tables that dealt with symbols and nomenclature. The Chairman has also participated, by correspondence, in the work of the Joint (with the International Mineralogical Association) Committee on Nomenclature.

The main activity of the Commission during the triennium has been a proposal for the compilation of an international crystallographic dictionary. According to the proposal, crystallographic terms would appear in all four languages used by the Union (and possibly one or two others as well), but the cost of the dictionary would be kept as low as possible by giving the definitions in English only. The Commission has planned an Open Meeting, to be held during the Tenth Congress in Amsterdam in 1975, at which this proposal will be further discussed, and other Commissions will present reports of their work in the field of nomenclature.

\section{April 1975. \\ A. J. C. Wilson, Chairman}

\section{(i) Commission on Crystallographic Studies at Controlled Pressures and Temperatures}

$\mathrm{Au}$ cours des trois années (1972-1975) qui viennent de s'écouler des différents membres de la Commission ont activement procédé à des échanges de vues par correspondance. De plus une réunion partielle groupant le $\mathrm{Dr}$ C. J. M. Rooymans, le Professeur K. F. Seifert, le Professeur J. C. Joubert et le Dr M. Foex s'est tenue à Paris le 27 Juin 1973.

\section{Colloques}

Le colloque 'hautes températures' d'Odeillo a fait l'objet d'une édition (CNRS, Paris, Février 1973) sous la responsabilité du Dr J. P. Traverse.

L'ouvrage de 488 pages groupe 55 mémoires. En dehors de la Conférence inaugurale du Professeur A. Guinier, alors Président de l'IUCr, on note les différentes parties suivantes:

(i) méthodes et appareillages (analyse thermique, diffraction des rayons $\mathrm{X}$, diffraction neutronique, diffraction électronique);

(ii) phénomènes d'ordre-désordre;

(iii) contrôle de la composition et non stoechiométrie;

(iv) transformations cristallines proprement dites;

(v) diagrammes de phases.

Il semble souhaitable par ailleurs qu'un autre colloque rentrant dans le cadre des activités de la Commission soit organisé dans le courant 1977. On peut penser en particulier qu'il serait bon de mettre l'accent sur le côté températures qui a été par ailleurs moins traité que les autres. L'IUCr pourrait être consultée à ce sujet au cours des réunions d'Amsterdam.

\section{Préparation des réunions d'Amsterdam}

Après avoir consulté les différents membres de la Commission son Président a proposé la réunion à Amsterdam, lors du 10ème Congrés International qui se tiendra au mois d'Août de deux 'Open Commission Meetings'.

(i) A joint Open Commission Meeting (Commission on Crystallographic Apparatus and Commission on Crystallographic Studies at Controlled Pressures and Temperatures) entitled 'Single Crystal Diffraction Measurements at Controlled Pressures and Temperatures', Chairman: Dr S. C. Abrahams.

(ii) An Open Commission Meeting entitled 'New Developments for Crystallographic Studies at Extreme Pressures and/or Temperatures. Calibration Methods', Chairman: Dr C. J. M. Rooymans.

En outre plusieurs des thèmes adoptés pour les commu- 
nications qui doivent être présentées à Amsterdam au cours de sessions scientifiques rentrent bien dans le cadre des préoccupations de la Commission. Il en est ainsi par exemple du thème 12 'phase transitions' ou encore du thème 18-5 'Instrumentation for studies (1) under high pressure, (2) at low temperatures, (3) at high temperatures'.

\section{Bibliographies et articles spécialisés}

Une revue bibliographique sur la diffractométrie des rayons $X$ à haute température (au dessus de $2000 \mathrm{~K}$ ) a été publiée par le Professeur J. P. Traverse dans la Revue International des Hautes Températures et des Réfractaires, (1973). 10, 125-129 dont le rédacteur en chef est le Professeur R. Collongues. Cet article qui fait suite à celle de H. J. Goldschmidt (1964) comprend deux parties: les techniques d'une part, les résultats d'autre part.

Dans le domaine des hautes pressions plusieurs membres de la Commission ont contribué à la réalisation de bibliographies ou d'articles spécialisés. Ainsi le Dr S. Block a indiqué que le N.B.S. avait aidé à réaliser différentes publications dans ce domaine. En particulier Bibliography on High Pressure Research in Chemistry and Physics (High Pressure Data Center, Brigham Young University, U.S.A.). D'autres articles spécialisés sont en cours de préparation. En ce qui concerne les phases nouvelles issues des hautes pressions on doit noter les travaux du Professeur J. C. Joubert et du Dr J. Chenavas New Phases from High Pressure (Handbook of Solid State Chemistry, Hannay, Bell Telephone, en cours de publication).

D'utiles liaisons ont été établies dans le domaine des monographies avec la Commission 'Crystallographic Apparatus', présidée par le Dr S. C. Abrahams, dont un des membres le Professeur R. Rudman a préparé un article spécialisé sur la diffraction $X$ à basse température qui groupe environ 400 références sur les appareillages et techniques, réalisés au cours des 15 dernières années.

Il serait souhaitable que les différents textes correspondant aux conférences présentés au cours des 'Open Commission Meetings' numeros 4 et 6 soient publiés sous forme d'articles spécialisés (dans le $J$. Appl. Cryst. par exemple), ou encore fassent l'objet de tirages susceptibles d'être mis à la disposition de ceux qui le souhaitent.

Problèmes d'échantillons 'standards' susceptibles de servir de référence pour les mesures de pression et de temperature

Le problème des 'calibrations' relatif aux hautes pressions a fait l'objet de nombreux travaux. Il s'agit d'un domaine difficile qui donnera en particulier lieu à un exposé du Dr S. C. Block du N.B.S. au cours de l 'Open Commission Meeting' numero 6 de l'IUCr à Amsterdam. On doit souhaiter que ce sujet qui intéresse la plupart des membres de la Commission fasse l'objet d'échanges de vue afin en particulier de rechercher les produits 'standards' présentant des transformations cristallines pour une pression donnée.

En ce qui concerne les hautes températures cette question est étudiée par la Commission des Hautes Températures et des Matériaux Réfractaires, présidée par le Professeur C. B. Alcock, cette Commission appartenant à I'Union Internationale de Chimie Pure and Appliquée (IUPAC). Un groupe d'études spécialisées a comparé par différentes méthodes les points de fusion de certains composés réfractaires susceptibles de servir comme étalons secondaires de température. Dans le même esprit on a commencé l'examen de certaines transformations cristallines à haute tempéra- ture. Des échantillons préparés à Odeillo ont été distribués pour ces études à différents laboratoires dans le monde. Par ailleurs des études précises de dilation du corindon ont été préconisées et entreprises au moyen de la diffraction des neutrons (Dr J. P. Traverse).

II serait souhaitable de trouver pour les hautes pressions des laboratoires susceptibles de produire et de distribuer des échantillons pouvant être utilisés dans le domaine de la 'calibration'.

\section{Relations de la Commission avec d'autres Commissions ou d'autres organismes}

Trois autres Commissions de l'IUCr sont représentées par leur président respectif. On doit noter en particulier une collaboration active avec la Commission 'Crystallographic Apparatus' et son président le Dr S. C. Abrahams. Cette collaboration a abouti à la 'Joint Open Commission Meeting' indiquée ci-dessus.

Dans le domaine des hautes températures des relations ont été établies avec la Commission des Hautes Températures et des Matériaux Réfractaires de l'IUPAC par le signataire de ce rapport comme cela a été noté.

I1 serait souhaitable de développer encore les relations avec l'extérieur, en recherchant d'autres spécialistes intéressés par les problèmes traités par la Commission. Une enquête effectuée dans le même esprit que celle réalisée par le Dr C. J. M. Rooymans pourrait préciser les besoins actuels ainsi que de découvrir de nouvelles voies, en suscitant si possible des travaux interlaboratoires plus nombreux.

30 Avril 1975.

M. Foex, Chairman

\section{(j) Commission on Crystallographic Teaching}

\section{General}

The Commission has not managed to hold any formal meetings during the inter-Congress period but the Chairman was able to visit several of the European members and consultants during a period of sabbatical leave in the first half of 1973. The Secretary has continued to produce a list of summer schools and attempts have been made to follow up the various proposals put forward in Kyoto, by correspondence, with rather limited success. The proposal to hold a summer school near to the time of the Tenth Congress has materialized, thanks to the efforts of Professor A. Authier, and it will be held at Limoges, France, 18-26 August, on the subject 'X-ray Dynamical Theory and Topography'.

\section{UNESCO Pilot Project}

The Laboratory Manual on Crystal Growth was published in 1972 and the last remaining item - The Atlas of Optical Transforms - was completed in 1974 and will be published in time for the Tenth Congress.

\section{Crystallography at school level}

Dr Elizabeth Wood's book Crystals - a Handbook for School Teachers was very warmly received. Professor Authier has translated it into French, Professor FontAltaba has produced a Spanish version and Professor Riva di Sanseverino is, I understand, producing an Italian version with Professor Rigault. Japanese and German versions are also under consideration. 


\section{Pamphlet programme}

At Kyoto the Commission planned to produce a series of short pamphlets in a standard format, each dealing with a specific technique or a method of teaching a specialized topic at a particular level. Short papers of 6-8 pages were envisaged in the hope that busy experts might find the time to contribute. Preliminary discussions on the possibility of publishing these with help from UNESCO, as an extension of the Pilot Project, were held but, as yet, little concrete material has emerged. It is possible that the summer school at Limoges will give rise to some items.

\section{Teaching crystallography and $X$-ray diffraction at uni-} versities

A start has been made on an enquiry into the timing and mechanism of the teaching of this subject at university level in the different countries represented by the Commission, partly as a means of providing background material for the presentation topic at the Tenth Congress concerned with integrated or independent teaching of crystallography in the university curriculum. Some responses are already available and, in particular, there has been a wide response from various parts of Africa thanks to the activities of Commission Consultant Michael Laing.

\section{Tenth General Assembly and Congress}

Plans are under way for various activities at Amsterdam and it is hoped to take full advantage of the Programme Committee's acceptance of the suggestion that participants may contribute a paper on the topic of crystallographic teaching, in addition to a paper on a scientific topic. The Open Commission Meeting will be on 'Teaching Aids for Crystallography'.

\section{ICSU Committee on the Teaching of Science}

The Chairman, as the Union's representative, has attended various meetings and has been elected Vicechairman of the Committee. He attended a conference on 'Training Teachers for Integrated Science' at the University of Maryland, U.S.A., in 1973. Further details of the activities of the Committee are contained in the report of the representative.

20 April 1975.

C. A. TAYloR, Chairman

\section{(k) Commission on Electron Diffraction}

The major activities of the Commission during the three years since the Ninth General Assembly are as follows:

(i) A. F. Moodie, in collaboration with three other members of the Commission and others, organized the sessions on the use of dynamical diffraction effects in the study of crystals at the International Crystallography Conference, Melbourne, 19-23 August 1974. The conference, with these sessions, which was held in connexion with the Eighth International Congress on Electron Microscopy, Canberra, 25-31 August 1974, marked a milestone in the progress of electron diffraction and electron-microscopic crystallography.

(ii) The working group on gas electron diffraction (L. S. Bartell, H. M. Seip and K. Kuchitsu) has completed and circulated a paper entitled $A$ Guide for Publication of Experimental Gas-Phase Electron Diffraction Data and Derived Structural Results in the Primary Literature. (iii) G. A. Somorjai has prepared a list of scientists who are working on surface crystallography.

(iv) The Commission is arranging two Open Commission Meetings, entitled 'Surface Crystallography' and 'Gas Electron Diffraction - Novel Species and Techniques', at the Tenth Congress at Amsterdam. K. Molière and H. M. Seip are working as the chief organizers of the respective meetings, in conjunction with A. J. van Bommel and J. L. Derissen in the Netherlands.

(v) The following matters are being considered for future activities of the Commission:

(a) Reconsideration of systems of units, notation and nomenclature in electron diffraction.

(b) Systematic compilation of the wave functions and intensities in HEED with respect to the various space groups.

(c) Elimination of certain theoretical inconsistencies in the formulation of the various branches of electron scattering.

Drafts of specific proposals for these activities are in preparation.

(vi) The Commission has decided to support the plan of Professor M. Blackman and Dr P. J. Dobson to hold a meeting at the Imperial College, London, in September 1977 to mark the Fiftieth Anniversary of Electron Diffraction.

25 April 1975.

G. Honjo, Chairman

\section{(l) Commission on Neutron Diffraction}

A conference on 'New Methods and Techniques in Neutron Diffraction' has been organized jointly by the Commission on Neutron Diffraction and the Reactor Centrum Nederland. It will be held at Petten, The Netherlands, 5-6 August 1975 , so as to facilitate attendance by participants at the Tenth Congress. It is hoped that the programme will also attract scientists who do not necessarily regard themsel ves as crystallographers but who, nevertheless, use diffraction techniques in neutron scattering and study problems closely related to structure.

The Commission project on intercomparison of powder neutron spectrometers has been completed and a draft report has been circulated for comment among the participants. A final report will be presented at the Neutron Diffraction Conference at Petten. At that time it is expected that plans for publication will be discussed. A second project to study single-crystal units has been initiated and is actively under way at the present time.

The Magnetic Structure Data Sheet compilation, which had just been started at the time of the Ninth Congress, has grown steadily and now contains approximately 180 entries. Modest subscription fees make the service selfsustaining. At the present time there are over fifty subscribers, including a number of libraries. It is becoming apparent that the compilation is not only useful as an indicator of current magnetic structure work, but that, particularly if it is supplemented with older work, it can become a very useful reference work for people in the field as well as for the 'consumer' of magnetic structure information.

The Commission is compiling critically evaluated magnetic-electron form factor data in cooperation with the ad interim Commission on Charge, Spin and Momentum 
Densities. The first results of this activity have been circulated through the Magnetic Structure Data Sheet Service.

The collection and publication of tables of neutron scattering amplitudes continues to be an important Commission activity. The most recent tabulation appeared in Acta Cryst. (1972). A 28, 327. The tabulation is not a 'critical' one at the present time but entries are carefully scrutinized by members of the Commission and by its consultants. A critical evaluation will probably be undertaken in future compilations.

The Commission is experimenting with the publication of a newsletter in which new developments in instrumentation and methods can be informally presented. The first issue has been circulated to workers in the field of neutron scattering. Future issues are expected to appear on an irregular basis as material becomes available.

\section{April $1975 . \quad$ L. M. CoRLIss, Chairman}

\section{(m) Ad interim Commission on Charge, Spin and Momentum} Densities

This Commission, which was created following the Ninth General Assembly, has devoted itself during the first three years of its existence to the initiation of those projects, in the general area of electron density studies, that are of direct interest to the crystallographic community.

Many crystallographers are interested not only in atomic positions in a crystal structure but also in the nature of the bonding between atoms and groups of atoms, i.e. in the details of the electron density (and spin density) in a great variety of systems. This is precisely the area which the ad interim Commission is concerned with; its aim is to explore the details of electron density distributions as revealed by X-ray diffraction, neutron diffraction and Compton scattering. [The latter yields the electron momentum density which, although an unfamiliar commodity to the crystallographer, is intimately connected with the spatial charge density - real space and momentum space wavefunctions are Fourier transforms of each other.]

Because of the accuracy required in all investigations of this type, the projects initiated by the Commission provide a critical assessment of the interpretative techniques of crystallography as well as yielding precise information on electron density distributions.

The Commission maintains a register of some 500 crystallographers, physicists, and chemists interested in the measurement and calculation of electron density. Triennial conferences (the 'Sagamore' conferences) are held on this topic; Sagamore IV was held in Minsk in 1973 and attended by about 100 delegates, Sagamore $V$ will be held near Helsinki in August 1976. The Commission first met in Minsk in 1973 and subsequently in Melbourne in 1974 to consider the projects and monitor their progress.

The projects of the Commission are outlined below.

\section{Events associated with the Tenth Congress}

Several meetings have been organised by the ad interim Commission to coincide with the period of the Congress.

(a) A summer school entitled 'A Crystallographer's Introduction to Charge, Spin and Momentum Density' is to be held at Warwick University in the week prior to the Congress. The course aims to provide an introduction to the basic physics underlying the theoretical, experimental and interpretative problems of this subject. (b) An Open Commission Meeting is to be held during the Congress. Oral reports on many of the projects will be delivered.

(c) A joint Open Commission Meeting with the Commission on Crystallographic Apparatus will be held during the Congress. The topic is 'Extinction Corrections, Theory and Experimental Measurement'.

\section{Projects completed}

(a) The water project. Compton scattering measurements made at five laboratories on water have been collated by B. G. Williams and analysed. After the correction of several systematic errors unearthed in the data sets, the agreement between experiments and with theory is very encouraging. A report on this project has been produced and will be published in due course [Acta Cryst. (1976). A 32, 513-526].

(b) X-ray absorption coefficients. A new compilation for selected $K$ wavelengths has been made by $\mathbf{J}$. Stiglich, R. J. Weiss and A. M. Hansen. Particular emphasis has been placed on the assessment of error in the tabulated values.

(c) Experimental techniques for electron momentum density measurements. This report by W. A. Reed contrasts and compares the different methods available in this field and discusses their suitability for various investigations. The formal report will be available shortly [Acta Cryst. (1976). A32, 676-690].

\section{Projects in progress}

(a) Accuracy of calculated scattering factors and Compton Profiles. The aim of this project is to ascertain the accuracy of form factors and Compton profiles calculated from wavefunctions of various types and quality. The coordinators K.-F. Berggren and V. H. Smith have received the cooperation of two dozen research groups. An interim report should be available before the Tenth Congress.

(b) Neutron form factors. The compilation of a compendium of neutron form factors by R. Moon and W. Koehler is proceeding steadily. This is a joint project with the Neutron Diffraction Commission and a report will be submitted through that Commission.

(c) Relativistic project. Relativistic calculations of form factors and Compton profiles are being compiled by J. T. Waber. Relativistic Hartree-Fock Compton profiles calculated by F. Biggs, L. B. Mendelsohn and J. B. Mann will be published shortly.

(d) Book on Compton scattering and allied techniques. A research monograph with contributions from several research workers is being compiled by B. Williams and will be published by McGraw-Hill.

(e) The absolute scale. It is intended to supply X-ray laboratories with silicon crystal slices for intensity standardization.

\section{Sagamore V}

This conference will take place 16-20 August 1976 at Kiljava, Finland. The local Chairman is K. Kurki-Suonio. The first circular regarding this conference has just been published.

\section{Summary}

The potential value of this Commission may be judged by the relevance and usefulness of the special projects undertaken during this initial explanatory three-year period.

It is suggested that the Commission should be con- 
tinued at least six more years in order that a considered critical assessment of its work can be made.

Copies of project reports are available for perusal from the Executive Secretary of the Union.

28 April 1975.

R. J. WeIsS, Chairman

Appendix D: Report on the Working Party on Information Services

\section{Introduction}

During its sessions in Kyoto (August-September 1972) at the ninth International Congress and Assembly of the IUCr, the Executive Committee examined the considerable involvement of the Union in matters of publication and allied activities. It was judged advisable that trends in these activities should be examined in order to adjust operational procedures in succeeding years if this proved necessary. An ad hoc committee was therefore set up during the Kyoto Congress to prepare appropriate terms of reference for the investigating body. Arising from its work, the Executive Committee therefore created the Working Party on Information Services with the following Terms of Reference, which were approved by the General Assembly:

1. To evaluate the present situation in relation to needs in the IUCr information services (e.g. publication, collection, storage, retrieval, critical appraisal and dissemination of data and other information pertinent to crystallography).

2. To project these needs into the future and to determine how the IUCr, primarily through its Commissions, should best meet them.

3. To make specific proposals for needed innovations to and extensions of services in this field. In these proposals, feasibility on economic, manpower and cost bases are to be specifically considered.

4. To report to the Executive Committee at its meetings in 1973 and 1974 and prepare a full report for circulation before and submission at the Tenth General Assembly in 1975.

The following individuals were invited to constitute the Working Party:

S. E. Rasmussen

F. R. Ahmed

J. D. Dunitz

T. Hahn

G. A. Jeffrey

A. I. Kitaigorodsky

K. Lukaszewicz

A. McL. Mathieson

M. Nardelli

T. Sakurai

J. Trotter

R. A. Young

D. G. Watson

The composition ensures that current Union activities in this field are represented while less-committed members will provide appropriate balance and impetus to consider both minor and major potential changes in procedures and content in relation to services for handling information.

This then establishes the function and composition of the Working Party.

\section{Survey of publications}

Item 1 in the terms of reference is dealt with first. The IUCr information services consist of the following publications and other activities:

\author{
Acta Crystallographica A+B \\ Journal of Applied Crystallography \\ Structure Reports \\ Molecular Structures and Dimensions in collaboration \\ with the Cambridge Crystallographic Data Centre \\ International Tables \\ Other periodic Union publications \\ Miscellaneous publications, monographs, etc.
}

These are complemented by a number of non-Union information services that are extensively used by crystallographers.

The survey is heavily biased towards services available in Western Europe and North America. The Chairman has very little information available on other services.

\section{Evaluation of information services \\ Primary publications}

Crystallography has links with a wide a range of scientific fields and crystallographic methods find important applications in solid-state physics, chemistry, biology, mineralogy, metallurgy and in different branches of technology. The main impact of crystallography appears to be in structural matters, judging from papers published, especially in IUCr journals. There has been a remarkable increase in the number of structural papers during the last decade (196575) attributable to the more widespread availability of highspeed computers and of automated equipment for data collection, combined with the development of powerful methods for solving structures. By contrast, budgets for scientific research are holding steady or even declining in many countries, so that we may expect some levelling off in the number of structural papers in the near future, although the statistics for Acta Cryst. do not point in this direction so far.

The rates of producing new papers and of publishing them are reasonably well balanced, at least as far as the IUCr journals are concerned. The main bottleneck nowadays may be that of writing structural papers. Information is being produced faster than results can be written up. The main problem facing Acta Cryst. is a financial one. In order to keep the financial risks in producing Acta within bounds, the Executive Committee has had to limit the size of Acta B to the 1973 level, and it is possible that this may have to be set at a lower limit in the future. If a backlog of structural papers is to be avoided, the average length must be decreased. The deposit scheme for structure factors should be made obligatory for all but the most exceptional cases, and other extensive lists of numerical data, e.g. temperaturefactor parameters, should also be deposited except for papers with a bias towards lattice dynamics, phase transitions, solid solutions, etc. More papers will have to go into the 'Short Structural Paper' section, and it appears that the Acta editors are convincing an increasing number of 
authors to condense their presentations. A cursory survey indicates that non-Union journals also cater well for structural papers and others of crystallographic interest. Papers on crystal growth, for instance, appear almost exclusively in non-Union journals.

\section{Collection, storage and retrieval}

The abstracting of information on crystal structures started early in the history of X-ray crystallography. In 1931 P. P. Ewald et al. published the first volume of Strukturbericht, which covered papers published in the years 1913-1928. The succeeding six volumes of Strukturbericht covered the years 1929-1939. After the war, with the creation of the IUCr, the survey of crystal structures was continued by the publication of Structure Reports, which by now covers the period 1940-1970, and by the end of this year the coverage will probably extend to 1973 . If the present pace of production is kept, Structure Reports is likely to remain the main source of retrospective information on structural papers. It is a classical publication in the sense that it is still produced by 'paper and pencil' work. Another source of retrospective information service has been created by the Cambridge Crystallographic Data Centre. Information on organic and organometallic crystal structures is stored on magnetic tapes and by using the potentialities of the computer a large number of cross-relationships may be retrieved. A very useful derivative compilation Interatomic Distances (1960-65) was published in 1973. The Data Centre publishes an annual bibliography Molecular Structures and Dimensions and also offers a Current Awareness Service with the same coverage to bridge the gap between the annual bibliography and the current literature. The citations are in the form of computer listings with entries grouped in 86 chemical classes.

The Commission on Neutron Diffraction offers a current awareness service on magnetic structures: The Magnetic Data Sheet Service, edited by Dr D. Cox at Brookhaven National Laboratory.

Another computerized current awareness service is offered by Chemical Abstracts. The subscriber receives citations according to one or more keywords, e.g. hydrogen bonding; neutron diffraction, etc.; the keyword can also be chosen in such a way that certain citations are suppressed. The Chemical Abstracts current awareness service is very complete and efficient but correspondingly expensive. Computerized retrospective literature search is also available to some extent from Chemical Abstracts, but it is again fairly expensive and actually difficult. If some related Union Commissions or other suitable organisations publish a list of standard keywords for certain fields of interest, and if these keywords are used for the subject index of the literature, the situation may be improved.

Classical methods such as reference to the printed pages of Chemical Abstracts, Bulletin Signalétique and similar sources continue to be the most extensively used current awareness service. Retrieval of information via the printed abstract journals appears still to be the most generally applied method.

Another non-Union information service which is of importance to crystallographers is I. D. Brown's Bond Index of Distances in Inorganic Crystal Structures (19691972) (not a current awareness service).

The collection, storage and retrieval of structural information is well organized both within the IUCr and in other organizations. However, other areas of crystallog- raphy are less well served. To mention a few examples: Information on structural defects (diffuse scattering), phase transitions, disorder and extinction is scattered through the literature and therefore difficult to abstract and to find. Some coverage is given by Chemical Abstracts and Bulletin Signalétique but is so incomplete that a systematic search is rather difficult. In these fields and in several others the Science Citation Index can be useful in tracing facts and interpretations.

\section{Critical appraisal, dissemination of data and other informa-} tion

Structure Reports used to set itself the goal of providing a critical assessment of published structures, and early volumes sometimes contained reports which were more valuable than the original papers themselves. Nowadays detailed critical appraisal of structural papers is too timeconsuming to be practically possible, and only the most obvious errors are likely to be found by the abstractors. However, the need for digestion and condensation of the vast amount of structural information produced is even more urgent than before. The trained crystallographer has reasonably easy access to this information, but it has to be made available to non-crystallographers, especially chemists, in an easily understandable and useful form. An attempt in this direction has been made by the Chemical Society in the Specialist Periodical Reports series, Molecular Structure by Diffraction Methods, of which two volumes have appeared.

Some efforts at appraising data critically have been made by the Commission on Crystallographic Apparatus, e.g. by organizing projects and a conference and, as previously mentioned, the Commission on Neutron Diffraction organizes a collection and dissemination of information on magnetic structures. Data bank files on protein structures have been established in the U.S.A. and the U.K.

For those who have easy access to files of this kind, a wealth of information is available in an easily retrievable form.

\section{Future needs}

Although extrapolations are often misleading, there are some trends from which some short-term predictions might be made.

The rate of production of crystallographic information will continue at much the same level as at present. Even if it should increase slightly, the problems of disseminating and abstracting this information will correspond approximately to the needs of today. However, the funds available for solving these problems appear to be diminishing in real value, and some changes may be forced on the Union information services. A rate of increase of say $5 \% p, a$. in the publishing activity of the Union would not be a cause for alarm if it were not coupled with a dwindling of the reserves of the Union. The publishing commissions will have to consider ways of reducing production costs. Libraries all over the world are faced with storage problems that can only be solved by miniaturizing stored information. Although information storage and retrieval based on computer services will probably gain steadily in importance, it seems unlikely that the computer terminal will replace the printed page within the next quinquennium.

The Commission on Crystallographic Data should continue to keep a careful watch on the establishment of centres for data acquisition and retrieval and should keep 
the crystallographic community informed of current developments in this field. It is too big a task for the IUCr to organize, let alone finance, the necessary developments in evaluating, compiling and disseminating crystallographic data through an international computer network. Only through its representatives on powerful international and national organizations can the IUCr exercise some influence on these developments.

\section{Specific Proposals to the Executive Committee and to} the Tenth General Assembly

The Working Party submits the following proposals to the Executive Committee and to the Tenth General Assembly and Congress:

(a) In order to make information more quickly available in spite of cost constraints, the average length of structural papers in Acta Crystallographica will have to be considerably shortened. More papers, maybe $70 \%$ of the total, should be published as Short Structural Papers. Tables of anisotropic thermal parameters should, in general, be deposited together with structure factor tables.

It may be useful to reconsider the form of Short Structural Papers; it may be possible to leave out description of methods which are standard, and economies might be obtained by using serial numbers for identification of references.

(b) The IUCr should investigate the feasibility of publishing Acta $\mathrm{B}$ as a synopsis journal, i.e. only the synopses would be printed in the usual way, the full papers being available on demand as microfiches. This suggestion will probably overlap with a similar one from the Working Party on Production Methods.

(c) Structure Reports should continue in its present form, but closer co-operation with the Cambridge Data Centre seems desirable so as to reduce duplication of effort. The burden on editors and abstractors could be lightened if the authors of structural papers were required to submit a report in a standard form (to be decided by the SR editor) on acceptance of a paper. This could be made obligatory for papers in Acta, and other journals may be willing to co-operate, although copyright problems may be encountered. If the proposal $(b)$ of a synopsis journal were adopted, the published synopsis could go directly into Structure Reports. The possibility of publishing a microfiche edition of Structure Reports in parallel with the usual hard copy should be investigated.

(d) There appears to be a need for transmitting the results of crystallography to scientists not trained in crystallography. This need can be partially met by periodic reviews, along the lines of the (U.K.) Chemical Society's Specialist Periodic Report series Molecular Structure by Diffraction Methods. There would be little point in duplicating this particular effort, but critical, authoritative reviews on problems connected with defect structures, phase transitions, and other more physical aspects of crystallography should be encouraged. If editors and authors could be found who were willing to serve the crystallographic community on the same terms as the other editors of the Union, such reviews could be produced by photolithography from typescript on the same cost basis as Structure Reports.

(e) The IUCr should investigate the feasibility of producing microfiche editions of back numbers of all its journals, reference works and tables. The General Secretary and Treasurer should be empowered to negotiate terms of microfiche editions, either with the present Union publishers or with other publishers specializing in this field.

(f) The proposals of the Working Party are rather conservative and, if put into practice, they would not involve the Union in costly and uncertain experiments. Progress in the field of information services is closely connected with technological developments. A comparatively small Union like the IUCr can hardly undertake projects that rely on large-scale applications of computers, but it can and should, through its Commissions, continue to help in defining the needs of crystallographers in the developments of computer-oriented information services.

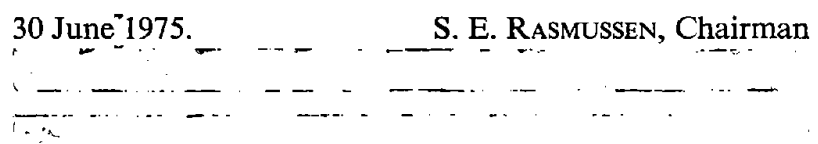

\section{Appendix E: Review of the activities of the Commissions of the Union}

As agreed at the Ninth General Assembly, the Executive Committee has examined the activities and problems of all the Commissions of the Union. Following a general discussion of the work of the present Commissions, the Executive Committee decided that one or more members of the Executive Committee should examine and review the work of each non-publishing Commission and present a report to the Executive Committee. The work of each publishing Commission was considered separately at the Executive Committee meeting. These reports formed the basis of the final report to the General Assembly, which is set out below.

Annual reports by the Executive Committee on the work of the Union are published in Acta Crystallographica Section A and include summaries of each Commission's activities. In addition, each Commission Chairman submits written triennial reports to the General Assembly. These reports are distributed to National Committees prior to each General Assembly and are published with the full report of the General Assembly and Congress. The full report of the Ninth General Assembly and Congress was published in 1973 (Acta Cryst. A 29, 730-772), and reprints were sent to Secretaries of National Committees and Commission Chairman.

The roles of the publishing Commissions are clearly defined. The publications of the Union are one of its major activities and continue to be of considerable importance and help to crystallography. Although the working of the publishing Commissions might be improved slightly by some changes, such as a limitation on the period of service on a Commission (as already applies to all other Commissions), in general the present situation is considered to be satisfactory. The Executive Committee has to devote a great deal of time to the financial matters concerning the publications.

\section{Commission on Journals}

The Commission was set up as an ad interim Commission by the Executive Committee in 1967; its establishment was confirmed by the Eighth General Assembly in 1969. It is responsible for the publication of the international journals Acta Crystallographica and Journal of Applied Crystallography. Before the latter journal was first published in 1968, there was a Commission on Acta Crystallographica, which was created at the First General Assembly 
in 1948 and was responsible for the publication of that journal. This Commission was dissolved in 1969.

The Editor of Acta Crystallographica is Chairman of the Commission on Journals and the Editor of the Journal of Applied Crystallography is Co-Chairman. The members of the Commission consist of the Co-editors of these journals and the Book-Review Editor. The Commission is responsible for the scientific standard of the journals, whereas the Executive Committee makes the financial decisions, such as fixing the subscription rates. The main problems facing the journals are financial ones, which directly concern the Executive Committee, but are also of concern to the Commission, since financial considerations may lead to restrictions in the size and content of the journals or to changes in the method and form of publication.

The Chairman of the Commission has represented the Union on the ICSU Abstracting Board for many years.

\section{Commission on Structure Reports}

The Commission was created at the First General Assembly in 1948 and is responsible for the publication of the annual volumes of Structure Reports. The Executive Committee maintains surveillance of the finances whilst the Treasurer and the Executive Secretary decide on the prices of volumes, and other financial matters. The Commission Chairman has made recommendations to the Executive Committee on changes in the format and also the method of printing. As a result of the increasing rate of publication of detailed crystal analyses, it became necessary, for Volume 30 (1965) onwards, to publish Structure Reports in two parts: A. Metals and Inorganic Compounds, and B. Organic Compounds (including organometallic compounds.). These changes, together with the devoted efforts of $\mathrm{Dr}$ W. B. Pearson, as General Editor for the volumes covering the literature up to the end of 1970, and Professor J. Trotter, as Chairman of the Commission and General Editor for the subsequent volumes, as well as the Section Editors and reporters, have enabled work to be maintained on many volumes simultaneously.

Five volumes were published at the end of 1974 and another five have already been published in 1975. All other volumes, up to and including Volume 39 (for 1973), are now with the printer and most of these volumes should appear later in 1975. The long-term future of Structure Reports will be considered in the report of the Working Party on Information Services, but the Executive Committee consider that, at present, Structure Reports continues to be of great use to the crystallographic community.

\section{Commission on International Tables}

The Commission was officially created at the First General Assembly in 1948, although a provisional international committee was set up in July 1946 to start the preparations for the publication of International Tables for $X$-ray Crystallography. The Commission is responsible for these volumes. Volume I, Symmetry Groups, was first published in 1952. Volume II, Mathematical Tables, was first published in 1959 and Volume III, Physical and Chemical Tables, was first published in 1962. Volume IV, Revised and Supplementary Tables for Volumes II and III, was published in 1974.

The work on the Pilot Issue for Series A: Symmetry Tables has been completed. The topic of symmetry was explored in considerable depth by the Commission in order to exploit the Pilot Issue to the full. Copies of the Pilot
Issue were sent to about 250 laboratories in various countries. A limited number of helpful, critical replies were received and the Commission drew up proposals for the budget, the time table and the execution of the new edition of International Tables for Crystallography. These proposals were subsequently presented to and discussed by the Executive Committee in 1974, when it was agreed to continue the preparation of a volume on tables for direct space, with the aim of publishing it as soon as possible. Full use of computer printing techniques is being made for the preparation and printing of these tables. This entails a considerable initial expenditure on the preparation of suitable computer programs.

\section{Commission on Crystal Growth}

The Commission was created in December 1966 by a postal ballot of the Executive Committee, in accordance with the authority empowered to it by the Seventh General Assembly earlier that year. The tasks of the Commission are to collect and disseminate information in the field of crystal growth and to maintain liaison between the Commission and the associations or national committees for crystal growth.

The Chairman of the Commission is one of the Union's representatives on the International Organization for Crystal Growth (IOCG).

In 1967 the Commission proposed many lines of activity, as follows:

(i) information exchange;

(ii) preparation of a list of scientists involved in the field;

(iii) preparation of a report on potential experimental and theoretical studies over the next five years;

(iv) preparation of a glossary of terms in four languages;

(v) preparation of a list of films;

(vi) organization of a topical meeting at the Eighth Congress of Crystallography in 1969;

(vii) organization of periodic summer schools.

The Commission met in person in 1969 and in 1971. Neither the Chairman nor any elected members (except Professor N. Kato and Professor I. Sunagawa, who were elected at the Ninth Congress) were present at the Ninth Congress in 1972, but several members were present at the Fourth International Conference on Crystal Growth held in Tokyo in 1974. Although plans on activities (iii), (vi) and (viii) above have materialized and two very successful summer schools have been held, there has not been much progress with the other projects.

Contact between the IOCG and the Union, through the Commission, has not been strong or active. The IOCG has considered the possibility of some association with the three Unions, IUCr, IUPAC and IUPAP, and the IUCr Executive Committee has made known its wish for closer ties. However, no practical suggestions have been offered by the IOCG.

The IUCr Executive Committee would like to see a closer relationship between crystal growers and crystallographers. This could best be achieved by closer contacts between the IUCr and the IOCG, and a strong and active Commission on Crystal Growth could be of great help in improving co-operation. The Commission should be maintained but it needs to be re-activated.

\section{Commission on Crystallographic Apparatus}

The Commission was created at the First General 
Assembly in 1948. Its aims then were to collect and disseminate information on crystallographic apparatus, models, etc., with the purpose of recommending desirable design features and encouraging investigations into apparatus, and to sponsor the preparation and production of graphical aids in crystallography.

The Commission continues to be one of the most active Commissions of the Union. It organizes exhibitions of non-commercial apparatus and gadgets, and of photography at the triennial Congresses. It has initiated and conducted experimental comparative studies in laboratories throughout the world. It has compiled four bibliographies and an Index of Crystallographic Supplies.

Its current projects include Phase II of the Single-Crystal Radiation Damage Survey, for which a two-year grant is being sought from the U.S. National Science Foundation. In addition to meeting at the triennial Congresses, the Commission has held meetings in 1971 and 1974. The latter meeting was on the occasion of the Conference on Anomalous Scattering in Madrid, which was organized by the Commission. The Proceedings of the conference are being published by the Union. The Commission is also organizing four Open Commission Meetings at the Tenth Congress, two of these meetings being organized jointly with other Commissions.

The Commission remains extremely active and should be continued. Several consultants have been appointed, and these scientists may be considered as potential members of the Commission.

\section{Commission on Crystallographic Computing}

The Commission was created at the Fifth General Assembly in 1960 and it is concerned with the collection and dissemination, on an international scale, of information on crystallographic computing. It has drafted a set of recommendations for crystallographic computing and presentation of the results. It has compiled and published a set of standard tests for crystallographic computer programs, and three editions of the World List of Crystallographic Computer Programs. It organized a summer school in 1969 and is organizing another one just prior to the Tenth Congress in 1975.

In 1971 the Commission Chairman summarized the tasks of the Commission as being the following:

(i) to enhance the exchange of novel computing methods, algorithms and programs among the crystallographers of the world;

(ii) to establish efficient and sound techniques for computer programming and data handling;

(iii) to provide verified results that would facilitate the checking of programs by individuals, and to help eliminate the common pitfalls and inaccuracies in crystallographic calculations;

(iv) to exchange information about recent developments in computer hardware and software in different countries.

The principal activities of the Commission remain the organization of summer schools and of Open Commission Meetings at Congresses and the publication of standard tests for crystallographic calculations. The response to a recent published appeal for new crystallographic programs was not sufficient to merit the preparation of a new edition of the World List of Crystallographic Computer Programs, even just for publication in the Union's journals.
The Commission remains very active. It is fulfilling its aims, under a dynamic Chairman, and should be continued.

\section{Commission on Crystallographic Data}

The Commission was created at the First General Assembly in 1948 with the object of promoting the collection and publication of crystallographic data and of maintaining liaison with other organizations in the field. It maintains contact with the ICSU Committee on Data for Science and Technology (CODATA) through its Chairman, who is an ex officio member of CODATA. CODATA regards the IUCr as one of the Unions most involved in data organization and critical evaluation.

It has published recommendations for the presentation of single crystal and powder data [Acta Cryst. (1967). 22, 445-449 and J. Appl. Cryst. (1971). 4, 81-86, respectively].

Most of the present activities of the Commission are the result of personal work by the Chairman. The Chairman has also contributed significantly to the Working Party on Information Services. A list of projects and recent publications dealing with crystallographic data is still in preparation.

The Commission is considering several long-term activities, including:

(i) trying to introduce a common format for the storage of all primary data in data centres;

(ii) encouraging the preparation and dissemination of readily accessible computer files containing crystal structure data;

(iii) developing standards in the reporting of data in the scientific literature;

(iv) acting as a collector of ideas from the crystallographic community about data, discovering data requirements and examining ways in which these requirements can be met;

(v) organizing Open Commission Meetings at Congresses to keep crystallographers informed of data developments and projects.

The Commission continues to act as an effective coordinator of information on data compilations, publications and requirements. It maintains effective contact with other organizations concerned with data, through ICSU CODATA, and should be continued, although perhaps there is need for closer co-operation with other Commissions whose interests include the field of data.

\section{Commission on Crystallographic Nomenclature}

The Commission was created at the First General Assembly in 1948. Its main object is to collaborate with the Editors of the publications of the Union in recommending a general acceptable nomenclature for use in these publications, and to act as an advisory body in connexion with problems submitted to it. Its membership consists of the four Editors of the Union's publications, and its Chairman is also a member of the Joint Committee on Nomenclature of the International Mineralogical Association and the IUCr.

The Commission has not been very active in the past, possibly not only because of a lack of nomenclature problems but also because all its members are heavily involved with the main publications of the Union. In 1973 the Commission suggested that the Union consider the preparation of a crystallographic dictionary. The Commission 
is organizing an Open Commission Meeting at the Tenth Congress to discuss this suggestion.

Although the Commission has not been active, it has conducted nearly all its business by correspondence and costs the Union almost nothing. It provides useful contact between the Editors of the Union's major publications and is able to consider problems of nomenclature as they arise. It is probably better to continue the Commission, with its limited membership, rather than dissolve it now and only re-establish it when an urgent need for decisions on nomenclature arises.

\section{Commission on Crystallographic Studies at Controlled Pressures and Temperatures}

The Commission was set up as an ad interim Commission, by the Executive Committee, in 1968 and its establishment was confirmed by the Eighth General Assembly in 1969 . Its object was to coordinate and sponsor the work on crystallographic studies at very high or very low pressures and/or temperatures.

The Commission exhibited no signs of activity after its establishment up to the time of the Ninth General Assembly, when its membership was reviewed and was increased by the addition of the Chairmen of the Commissions on Crystallographic Apparatus, Electron Diffraction and Neutron Diffraction, as ex officio members. It was hoped that this would increase the communication and co-operation between these four Commissions.

Four members of the present Commission met in 1973, when several recommendations were made for future activities, as follows:

(i) organization of several meetings, including Open Commission Meetings at Congresses;

(ii) consideration of the possibility of holding an interCongress Conference in 1977;

(iii) publication of bibliographies for X-ray and neutron diffraction at high pressures and high temperatures;

(iv) preparation of review articles on studies at high and low temperatures and at high pressures;

(v) consideration of the problems of pressure calibration at high pressures.

The Commission should be continued if this will enable satisfactory progress to be made with most of these projects and if this progress would not have been made otherwise. Active participation in these projects could involve many scientists, not just the members of the Commission, in active international co-operation. Perhaps more Consultants should be appointed to the Commission.

\section{Commission on Crystallographic Teaching}

The Commission was created at the Third General Assembly in 1954, with the object of facilitating and furthering work on the teaching of crystallography, by all suitable means.

Under the IUCr-UNESCO project on the teaching of crystallography, funds were provided by UNESCO to assist in the development of some new learning materials in the field of crystallography. Most of these activities are now complete and the Atlas of Optical Transforms, by Professor C. A. Taylor, will be published later this year by G. Bell and Son Ltd.

Dr E. A. Wood's book Crystals - a Manual for School Teachers has been or is being translated into French,
German, Italian, Japanese and Spanish by members of the Commission. Other current proposals include the preparation of small pamphlets on particular teaching problems in crystallography; the consideration of the problem of training specialist technicians for crystallographic laboratories; the compilation of a list of teaching experiments which can be performed with inexpensive equipment; the compilation of model syllabi for crystallography courses intended for students of other disciplines.

The work of the Commission attracted a good attendance at the Open Commission Meeting in 1972. However, the Commission is experiencing difficulties associated with working by correspondence. Nevertheless, it is responsible for a very important area of crystallography and has an interesting and ambitious programme. The existence of the Commission should be continued.

The Chairman of the Commission is the Union representative on the ICSU Committee on the Teaching of Science, whilst the Secretary is the alternate.

\section{Commission on Electron Diffraction}

The Commission was created at the Fourth General Assembly in 1957. Its objects are to promote the collection and exchange of information in the field, to maintain cooperation with the other Union Commissions and with international bodies interested in electron diffraction, and to assist in organizing sessions on electron diffraction at IUCr Corgresses.

Several members of the Commission were involved in the organization of the sessions on the use of dynamical effects in the study of crystals, at the International Crystallography Conference which was held in Melbourne, Australia in August 1974. The Commission's working group on gas electron diffraction has completed a guide for the publication of experimental gas-phase diffraction data and derived structural results in the primary literature. This draft document has been distributed widely to appropriate laboratories. Professor Somorjai has compiled a list of scientists working in the field of surface crystallography. Because the Commission covers the fields of high-energy and gas electron diffraction, it experiences inevitable difficulty in finding activities which would involve and interest all its members.

Future activies which might be undertaken by the Commission include the study of problems associated with:

(i) the investigation of surfaces by LEED and related methods;

(ii) structure investigations by HEED;

(iii) investigations connected with electron microscopy and, in particular, microdiffraction;

(iv) the dynamical scattering of electrons;

(v) the present system of units, designations and nomenclature in electron diffraction;

(vi) the development of considerations which govern the symmetry of wave functions and intensities in HEED. A systematic compilation with respect to the various space groups might be undertaken.

In addition, several members of the Commission may be involved in the organization of a special meeting in London in 1977 , to mark fifty years of electron diffraction.

The Commission is reasonably active, although it might benefit from a long-term plan of various projects involving every member of the Commission. 


\section{Commission on Neutron Diffraction}

The Commission was created at the Seventh General Assembly in 1966. It was to be concerned with those aspects of crystallography which can be studied amost uniquely by using neutron beams. These include the satisfactory detection of light atoms (particularly hydrogen), the detection and description of magnetic architecture, and the study of crystal dynamics from inelastic scattering data.

Recent projects include:

(i) the collection and publication of tables of neutron scattering amplitudes;

(ii) the compilation of magnetic structure data sheets;

(iii) the compilation of critically evaluated magnetic electron form factors;

(iv) an evaluation of spectrometers at different reactors;

(v) the publication of a newsletter;

(vi) the organization of a neutron diffraction meeting at Petten, The Netherlands, prior to the Tenth Congress.

The Commission is serving the crystallographic community well by carrying out worthwhile, useful projects, although the necessity of doing work by correspondence slows down the rate of progress. The Commission should be continued.

\section{Ad interim Commission on Charge, Spin and Momentum Densities}

The Commission was created, ad interim, by the Executive Committee in 1973, in accordance with the resolution of the Ninth General Assembly in 1972. The future of the Commission will be considered fully by the Tenth General Assembly in 1975. The Commission's terms of reference were to promote the study and resolution of the factors which limit accuracy in crystallographic studies relating to charge, spin and momentum densities. Since various different scientific approaches may be used for these studies, it is necessary to co-ordinate the different studies and to promote interdisciplinary co-operation between physicists and crystallographers.

Several members of the Commission met in 1973 and in 1974 and the Commission is currently involved in many activities, including the following:

(i) the comparison of Compton scattering measurements on water from different laboratories;

(ii) the compilation of a report on data processing and assessment of momentum space experiments;

(iii) the compilation of a compendium of neutron form factors;

(iv) the comparison of $a b$ initio calculations of form factors and Compton profiles;

(v) the organization of a summer school on charge, spin and momentum densities;

(vi) the co-ordination of calculations of relativistic form factors and Compton profiles for heavy atoms;

(vii) the standardization of intensity measurements;

(viii) the preparation of a book of review articles on Compton scattering

(ix) the revision of absorption coefficients published in International Tables;

(x) the organization of future Sagamore conferences.

The Commission has shown a high degree of enthusiasm and activity since it was formed early in 1973. The General Assembly will consider whether the Commission should be continued, when it meets in August 1975, but the Exec- utive Committee feels that the Commission is serving a useful purpose and could continue to do so, particularly if it maintains close contact with the main body of crystallographers and with other IUCr Commissions, such as those concerned with apparatus and with neutron diffraction.

\section{Appendix F. Reports of the Representatives on bodies not belonging to the Union}

\section{(a) IUPAP Commission on the Solid State}

During this period the main concern of the Commission has been the sponsorship of international conferences. The IUPAP has instituted a standard checklist which must be filled out by conference organizers seeking sponsorship, to ensure that adequate consideration has been given to the scientific value and international character of the intended conferences. There has been some discussion within the Commission on the problems of coordination of international conferences, including the avoidance of overlapping of dates and the maintaining of a reasonable geographical distribution of conference sites.

The conferences sponsored by the IUPAP on the recommendation of the Commission since the last triennial report include the following. Financial support is indicated by an asterisk.

* Fourth International Conference on Solid Compounds of Transition Elements, Geneva, Switzerland, 9-13 April 1973.

*Lattice Defects in Ionic Crystals, Ile de Bendor, France, 2-7 July 1973.

*Sagamore IV: Electronic Charge, Spin and Momentum Densities, Minsk, USSR, 13-18 August 1973. Cosponsored by IUCr.

* Fifth International Conference on Internal Friction and Ultrasonic Attenuation, Aachen, B.R.D., 27-30 August 1973.

*First Specialized Ampère Colloquium: Nuclear Magnetic Resonance in Solids, Cracow, Poland, 28 August-1 September 1973.

*Third International Meeting on Ferroelectricity, Edinburgh, U.K., 10-14 September 1973. Co-sponsored by IUCr.

* Fifth International Symposium on Magnetic Resonance, Bombay, India, 14-18 January 1974.

* Fourth International Conference on Crystal Growth, Tokyo, Japan, 24-29 March 1974. Co-sponsored by IUCr.

Third NEVAC Symposium on Surface Physics: The Solid-Vacuum Interface, Utrecht, The Netherlands, 2628 June 1974.

International Conference on X-ray Processes in Matter, Helsinki, Finland, 29 July-1 August 1974.

*Colour Centres in Ionic Crystals, Sendai, Japan, 19-23 August 1974.

International Conference on the Applications of the Mössbauer Effect, Bendor, France, 2-6 September 1974. International Conference on Electronic Structure of Actinides, Argonne, U.S.A., 9-11 October 1974.

III International Conference on Light Scattering in Solids, Campinas, S.P., Brazil, 25-30 July 1975.

Third International Conference on Vapour Growth and Epitaxy, Amsterdam, The Netherlands, 18-21 August 1975. Co-sponsored by IUCr. 
*1975 International Conference on Luminescence, Tokyo Japan, 1-5 September 1975.

* Low Lying Lattice Vibrational Modes in Ferroelectrics and Superconductors, San Juan, Puerto Rico, 1-4 December 1975.

The Secretary of the Commission is Dr G. Szigeti, Research Institute for Technical Physics, Hungarian Academy of Sciences, Fóti ut 56, Budapest IV, Hungary, who may be contacted for further information.

\section{May 1975.}

J. M. CowLeY, Representative

(b) Conference Committee of the European Physical Society

The Committee has met twice a year in the period 1972-

75. The Committee consists of delegates of European physical societies and of Divisions of the European Physical Society, and representatives of relevant international Unions. It is interested in a wide spectrum of topics covered by scientific meetings of European physicists. Because of this fact, only a small part of the meetings were of interest to crystallography, so that the IUCr representative concentrated mainly on following the activities of the Committee with the intention of obtaining and exchanging information on scientific meetings of common interest.

The IUCr representative took part in postal votes concerning the sponsorship of the European Physical Society for various meetings. The Committee devotes careful attention to these requests for sponsorship, because of the relatively rich conference activity of European physicists. The number of physical meetings receiving sponsorship by the European Physical Society greatly exceeds the number of crystallographic meetings receiving IUCr sponsorship.

\section{April 1975.}

A. LíneK, Representative

\section{(c) International Organization for Crystal Growth}

The Council of the International Organization for Crystal Growth (IOCG) met prior to the General Assembly, held in Tokyo, in March 1974, at the time of the Fourth International Conference on Crystal Growth. A new constitution was prepared and was ratified by mail, by a majority vote of the participants of the first three International Conferences on Crystal Growth. The General Assembly decided that IOCG should seek affiliation to IUPAC, IUPAP and IUCr, within the framework of ICSU. The contact should be loose, however. Since this decision, no progress has been reported to Council members.

In addition to the Fourth International Conference on Crystal Growth (IGCG-4), mentioned above and attended by 750 participants, the Second International Spring School on Crystal Growth (ISSCG-2), attended by 209 participants, was also held in Japan in 1974. The attendance at these conferences is increasing. It is noteworthy that crystallographic techniques such as topography are gradually becoming more important.

ICCG-5 and ISSCG-3 will be held in the U.S.A. in 1977 (cf. the report of the Commission on Crystal Growth).

7 May 1975.

P. HARTMAN, Representative

\section{(d) ICSU Abstracting Board}

The ICSU Abstracting Board has met annually; in Ustao- set, Norway, in 1972; in London in 1973; and in Berlin in 1974, this meeting being also a general assembly. In each case there were numerous meetings of the committees associated with the main Board meetings. In 1972 and 1973 there were also programmes planned particularly for the numerous invited observers, but in 1974 there were business meetings only.

The Board has been active in facilitating cooperation between primary publications and secondary services, having set up a joint working group in 1971. This working group arranged a full-day meeting in 1972, the morning being devoted to general questions of cooperation and the afternoon to indexing. A small pamphlet produced by this group has been very widely distributed. In 1973 two days were devoted to a Conference of Editors with the title 'Primary publication and secondary services: partners in information flow'. The meeting, attended by approximately 125 registrants, was arranged by the ICSU Abstracting Board with the support of the Royal Society, and the papers have since been published by the Board.

In 1973 the ICSU Abstracting Board and CODATA set up a joint working group to collaborate on matters of mutual interest, and it is interesting that both the Board and CODATA nominated the representatives of the IUCr to the joint working group. The main matters considered have been the use made by information dissemination centres of the products of secondary services, and the proposal that abstracts of papers containing new data should be 'flagged' (in a simple fashion) or 'tagged' (in a sophisticated fashion, possibly machine-readable) in order to facilitate retrieval. With UNESCO support this joint working group held meetings in 1974 and early 1975, and a report on 'flagging' or 'tagging' is in preparation.

The Board has devoted a great deal of effort to the compilation of an 'aggregate list' of all journals abstracted by one or more members of the Board. When this is completed it is expected that it will be of great help in improving coverage and increasing efficiency, as 'fringe' journals will not need to be skimmed by several services. The Board has collaborated actively in developing an international scheme for registering journals and assigning a unique number (so-called ISSN) to each.

The next meeting of the Board will be held in Brussels in June 1975. One of the major topics will be the provision of information services in the developing countries.

\section{April $1975 . \quad$ A. J. C. WILSON, Representative}

\section{(e) ICSU Committee on Data for Science and Technology (CODATA)}

In July 1973 the Task Group on Computer Use organised a Conference on 'Man-Machine Communication for Scientific Data Handling' at the University of Freiburg, B.R.D.

In September 1973 the Eighth General Assembly of CODATA was held in Stockholm. A new draft Constitution was approved by the delegates and since then some amendments have been introduced to conform to ICSU conventions. A major factor involved in the new Constitution was the reorganisation of the Secretariat and the replacement of the Bureau by an Executive Committee. The new Executive Secretary, B. Dreyfus, has an office in the ICSU building in Paris.

The Task Group on Presentation of Data in the Primary 
Literature has completed its report and this has been published as a CODATA Bulletin. Versions of the report in languages other than English will be prepared.

The Task Group on Accessibility and Dissemination of Data has submitted its report of Study on the Problems of Accessibility and Dissemination of Data for Science and Technology to UNESCO, who have published it as a UNISIST document. It has also embarked on a feasibility study of the establishment of a referral centre for numeric data. This work is being done under contract to UNESCO and involves the acquisition and analysis of a large body of information relating to existing data referral practices. The analysis of the questionnaries will be done in May 1975 and it is planned that the report will be submitted to UNESCO in October 1975.

The Ninth General Assembly and International Conference of CODATA took place in Tsakhcadzor, Armenian S.S.R. in June 1974. A full report of this meeting has been submitted to the IUCr Executive Committee.

The Joint Working Group of CODATA and ICSU Abstracting Board has continued its study of the problem of flagging data in primary and/or secondary literature. The basic work under the present UNESCO contract has now been completed and the report is in preparation. This report will make proposals for a more extensive study of this important and difficult problem.

CODATA publications, Newsletter and Bulletin, are now being produced in-house at the Secretariat and these are available on a subscription or per-issue basis.

\section{April 1975. \\ D. G. WATSON, Representative}

\section{(f) ICSU Committee on the Teaching of Science}

\section{General}

Only two full meetings of the Committee have been held in the inter-Congress period. It was not possible for the Union to be represented at either meeting. The first was held in September 1972 when both the Union representative and alternative were returning from the Ninth General Assembly in Japan. The representative was prevented from attending the second meeting, in May 1974, because of a family bereavement and there was not sufficient notice for the alternate to attend. However, the Union representative has attended four meetings of officers, two informal consultations at UNESCO and two meetings of working parties. Dr A. Baez has now succeeded Professor M. Matyas as Chairman of the Committee and the Union representative was elected Vice-Chairman of the Committee in 1974.

\section{Conference on the Training of Teachers for Integrated} Science, 3-13 April 1973

About 200 participants from 60 countries attended the conference at the University of Maryland, U.S.A. The full proceedings of the conference have now been published by the UNESCO Press as New Trends in Integrated Science, Vol. III. The conference was very stimulating and its greatest value lay in the exchange of experiences between representatives of so many countries and in the opportunities for discussions about ways of adapting experiences to suit varying needs. The value of subjects such as crystallography, as vehicles for teaching integrated science at all levels, was stressed. Following the conference a meeting to launch a new association, the International Council of
Associations of Science Education, was held and the new body is affiliated to the ICSU Committee on the Teaching of Science.

\section{Educational Technology}

The proceedings of the seminar organised by the Committee in September 1973 have now been published by the UNESCO Press under the title New Trends in the Ulitization of Educational Technology for Science Education.

\section{Current activities}

(a) Preparations are in hand for a seminar on the problems of evaluation in integrated science, which is to be held in December 1975 at Oxford, U.K.

(b) A preliminary investigation into new approaches to teaching/learning strategies in university science is being carried out by small working parties in the U.K. and U.S.A. The Union representative is convenor of the U.K. working party.

(c) Plans to hold an international meeting on the problems of teaching mathematics for application in other sciences are being prepared jointly with the International Commission on Mathematics Education (ICME) of the International Mathematical Union. There is a tentative suggestion that the meeting might be held immediately before the next International Congress, in Germany in 1976.

(d) It is hoped to draw all the Unions' teaching commissions into a seminar, to be held in 1976 , on the contributions that the specialist disciplines, such as geology, astronomy and crystallography, can make to teaching science at school level. The IUCr teaching commission is being asked to take part.

(e) Joint plans with COSTED and SCOPE, leading to seminars on environmental science education, are being evolved.

( $f$ ) The advisory functions to the Science Teaching and the Science and Technology divisions of UNESCO continue to occupy an important place in the deliberations of the Committee.

\section{April $1975 . \quad$ C. A. TAYLOR, Representative}

(g) ICSU Committee on Space Research (COSPAR) Organizing Committee concerned with problems of Physics and Chemistry in Space

At a COSPAR meeting in 1974 a proposal was made to set up a working party to deal with problems of physics and chemistry in space. Although there was considerable interest in this new field of research, it was not clear whether a new body should be created. Consultation with the appropriate international Unions, IUPAC, IUPAP and $\mathrm{IUCr}$, was recommended.

An organizing committee has been established by COSPAR, and the IUCr was invited to nominate a representative. After consultation with the Chairman of the Union's Commission on Crystal Growth, the Executive Committee appointed Dr E. Kaldis, a member of that Commission, to represent the Union at a forthcoming meeting of the committee, to be held at the COSPAR meeting in Varna, Bulgaria in June 1975.

Appendix G: IUCr-IMA Joint Committee on Nomenclature The Joint Committee was set up by the International 
Union of Crystallography and the International Mineralogical Association in 1970 to consider nomenclature problems that are common to the two disciplines, with particular emphasis on the problems dealing with the polytypism of layered structures.

Since the last General Assembly in 1972 this Committee has concentrated on development of structural notation systems that can be applied to differentiate polytypic stacking sequences of layers of any structural type. Review of notation systems presently in the literature indicated that most such systems were developed for specific structures and could not be applied universally. Three systems, however, offered sufficient promise that attempts have been made to modify them for universal application.

A system by J. A. Gard (Aberdeen) has been modified by A. Kato and H. Schulz of this Committee. This is a short system that can be used without knowledge of the crystal structure and is based on resultant symmetry and periodicity. It makes allowance for superstructures along any of three axes as well as for interchange of axes. It will be useful for differentiation of polytypes provided the number of polytypic structures of the same symmetry and periodicity is not large.

A more complete system of notation is desirable when the structure is known and the exact orientation and position of each layer in the sequence must be indicated. B. B. Zvyagin (Moscow) and K. Dornberger-Schiff (Berlin) \& S. Durovič (Bratislava) were requested to modify earlier published systems of this type in order to facilitate application to different structural types. The Zvyagin system uses two sets of symbols with subscripts to indicate the relative displacement of specified origins between component sheets within layers and also between layers, with superscripts to indicate the orientations of the sheets. The Dornberger-Schiff and Durovič system adopts some of the features of the Zvyagin system but, instead of using stereochemical features as building blocks, uses the symmetry relations between asymmetric units. It is based on OrderDisorder theory. The Committee presently is studying both systems and anticipates a final report during 1975.

\section{March 1975.}

\section{S. W. Bailey, Chairman}

\section{Appendix H: Summary of the activities of the Sub-committee on the Union Calendar}

This Sub-committee is a sub-committee of the Executive Committee and therefore, according to Statute $8 \cdot 1$, has no obligation to report to the General Assembly. However, a summary of its activities is given in this Appendix for the information of delegates.

During the period since the Ninth General Assembly, the Sub-committee has considered many requests for sponsorship and financial support by the Union, and has made recommendations accordingly to the Executive Committee. The following meetings on topics of crystallographic significance have received Union sponsorship. Meetings which also received financial support from the Union are indicated by an asterisk. The list includes meetings held after the Ninth General Assembly but which were awarded Union sponsorship by the Executive Committee before the end of that General Assembly.

*Third International Symposium on the Chemistry of the
Organic Solid State, Glasgow, U.K., 18-22 September 1972.

*Symposium on the Structure of Biological Molecules, Stockholm, Sweden, 9-11 July 1973.

*Sagamore IV, Minsk, U.S.S.R., 13-18 August 1973.

*Third International Conference on Small-Angle Scattering, Grenoble, France, 5-7 September 1973.

*First European Crystallographic Meeting, Bordeaux, France, 5-8 September 1973.

*Third International Meeting on Ferroelectricity, Edinburgh, U.K., 10-14 September 1973.

* Fourth International Conference on Crystal Growth, Tokyo, Japan, 24-29 March 1974.

*Second International Spring School on Crystal Growth, Mt. Fuji District, Japan, 31 March-7 April 1974.

*Conference on Anomalous Scattering, Madrid, Spain, 22-26 April 1974.

* International Discussion Meeting on Studies of Lattice Distortions and Local Atomic Arrangements by X-ray, Neutron and Electron Diffraction, Jülich, B.R.D., 29 April-3 May 1974.

Symposium on Intra- and Intermolecular Forces, Pennsylvania State University, U.S.A., 14-16 August 1974.

* International Crystallography Conference on Diffraction Studies of Real Atoms and Real Crystals, Melbourne, Australia, 19-23 August 1974.

*Second European Crystallographic Meeting, Keszthely, Hungary, 26-29 August 1974.

Fourth International Symposium on the Organic Solid State, Talence, France, 17-19 July 1975.

*Summer School on Electron Charge, Spin and Momentum Density, Coventry, U.K., 27 July-2 August 1975.

*International Summer School on Crystallographic Computing, Prague, Czechoslovakia, 28 July-5 August 1975.

* Neutron Diffraction Conference, Petten, The Netherlands, 5-6 August 1975.

Third International Conference on Vapour Growth and Epitaxy, Amsterdam, The Netherlands, 18-21 August 1975.

*Summer School on X-ray Dynamical Theory and Topography, Limoges, France, 18-26 August 1975.

Third European Meeting on Ferroelectricity, Zürich, Switzerland, 22-26 August 1975.

Course on Crystal Growth, Erice, Sicily, Italy, 30 August7 September 1975 .

A list of meetings of interest to crystallographers is published in each issue of the Journal of Applied Crystallography. Attempts to make this list as comprehensive as possible depend to a large extent on the Executive Secretary being informed of relevant meetings by National Committees and individual crystallographers.

\section{Appendix I: Budget estimates for the period to the Eleventh General Assembly; determination of the unit contribution}

\section{(a) Budget Estimates}

As previously, an estimated budget for the period until the next General Assembly has been prepared for the General Fund only. Since the budget estimates had to be prepared at a time when the decisions on many activities had still to be made, these estimates should be considered with due reserve. With this proviso, and in accordance with 
Statute 9.3, the Executive Committee presents to the Tenth General Assembly the following estimates for the three-year period 1 January 1975-31 December 1977.

Income

Subscriptions from Adhering Bodies

Yield from investments and banking accounts

Subventions from UNESCO through ICSU

Sale of incidental publications

\section{Expenditure}

Administration

Subscriptions to ICSU

Administrative 'Meetings

Scientific Meetings

Cost of incidental publications

Estimated deficit and bodies of ICSU

\section{$\$$}

79,800

54,000

12,000

200

$\$ 146,000$

81,000

4,000

44,000

20,000

- $\frac{\$ 149,000}{-\$ 3,000}$

Because of inflation, the real value of the investments of the Union is steadily declining. The investments are also diminishing because it is not possible to replace the bonds which are redeemed with new investments. The subvention from UNESCO has been reduced, and it has been necessary for the Executive Committee to suggest a nominal increase in the unit contribution to U.S. $\$ 220$. This increase is hardly enough to compensate for the general rise in the average costs of operating the Union.

In previous years, the yield from investments approximately balanced the administrative expenditure. This is no longer so, and part of the income from subscriptions must be used towards the expenditure on administration. As in the previous triennium, the above budget assumes that part of the expenses of administration $(\$ 36000)$ will be charged on the publication accounts. Thus the total expenses of administration are estimated as $\$ 117000$.

Expenses included under 'Administrative Meetings' are those of the Executive Committee meetings, Union representation on other bodies, and the printing of the report of the General Assembly. In order to make a reasonably balanced budget for the general fund the item 'Scientific Meetings' has to be cut severely in comparison with previous years. This item includes expenses of nonpublishing Commissions, financial assistance given to scientific meetings organized or sponsored by the Union, and expenses of Commission Chairmen and of the Programme Committee for the triennial Congresses of Crystallography.
As the Executive Committee is required by By-Law 2.1 to meet at least twice during the period between General Assemblies, it is only possible to cut down on the expenses of this item by a change in the By-Laws. Although the expenditure on administration is the largest single item in the budget for the General Fund, it should be remembered that, considering the many activities of the Union, it is necessary to employ a salaried Executive Secretary. The rent paid for the accommodation of the Chester office is probably the lowest you could get in Western Europe, and salaries in Britain are for the time being amongst the lowest in Western Europe. In comparison with the costs of operating the Union elsewhere, the expenditure on administration is in reality a very moderate one.

\section{(b) Unit Contribution}

According to Statute $5 \cdot 10(k)$ the General Assembly has to determine the unit contribution from the Adhering Bodies for the period to the next General Assembly.

The Executive Committee considers it necessary to recommend an increase in the unit contribution from 1 January 1976. National Committees were first advised of the Executive Committee's intention in September 1973 and were informed of the details of the proposal in August 1974.

The last time that the unit contribution was increased was at the General Assembly in 1972, when it was raised from $\$ 100$ to $\$ 160$ as from 1 January 1973 . In view of the considerable increase in the Union's activities since then, the necessity of employing a salaried Executive Secretary, the substantial increases in costs in the last three years, the fluctuations in exchange rates resulting in an effective devaluation of the U.S. dollar, and the wish to continue financial support to scientific meetings and Commissions, the Executive Committee now proposes, on the basis of the budget shown in Section $(a)$ above, that the unit contribution be increased from 1 January 1976 to U.S. \$220 for the years 1976, 1977 and 1978. The proposal to keep the unit contribution constant for these three years has been made in the light of the decision of the Ninth General Assembly, namely to fix the unit contribution constant at $\$ 160$ for the three years 1973, 1974 and 1975 and not to approve the proposal of the Executive Committee to increase the unit contribution to $\$ 200$ for 1975 .

The above proposal is made on the basis of exchange rates in force on 5 July 1974 (U.S. $\$ 100=$ Swiss F $2 \cdot 98=$ U.K. $£ 0 \cdot 414=$ Netherlands $f 2 \cdot 65$ ). Should significant alterations to exchange rates occur before the General Assembly, the Executive Committee may consider it necessary to make supplementary proposals or to designate the unit contribution in terms of another currency (Statute 9.5). 


\title{
ANNEX II
}

\section{Statutes and By-Laws of the International Union of Crystallography}

\author{
as Adopted by the Fourth General Assembly in 1957 and Amended by the Fifth General Assembly in 1960, \\ the Sixth General Assembly in 1963, the Seventh General Assembly in 1966, the Eighth General Assembly \\ in 1969, the Ninth General Assembly in 1972, and the Tenth General Assembly in 1975
}

\section{Statutes}

\section{Objects of the Union}

1.1. The objects of the Union are

(a) to promote international cooperation in crystallography;

(b) to contribute to the advancement of crystallography in all its aspects, including related topics concerning the non-crystalline states;

(c) to facilitate international standardization of methods, of units, of nomenclature and of symbols used in crystallography;

(d) to form a focus for the relations of crystallography to other sciences.

1.2. For these purposes the Union shall have the power

(a) to adhere to the International Council of Scientific Unions;

(b) to organize international meetings and conferences on subjects falling within the purview of the Union;

(c) to promote international publication of crystallographic research and of crystallographic works;

(d) to set up Commissions or other bodies for special objects;

(e) to initiate, promote and coordinate crystallographic research requiring international cooperation;

$(f)$ to organize Special Projects which shall be financed independently of the regular operations of the Union;

$(g)$ to participate in Joint Commissions with other Unions or other scientific bodies in matters of interest to the Union;

(h) to perform all such other legal acts as are essential for or conducive to the objects of the Union including the constitution or organization of separate or independent bodies having an appropriate legal status.

\section{Organization and Legal Domicile}

$2 \cdot 1$. Under the name of International Union of Crystallography an Association has been organized and incorporated; it is governed by Articles 60 and following of the Swiss Civil Code and by the present Statutes of Incorporation.

$2 \cdot 2$. The duration of the Union is not limited.

2.3. The legal domicile of the Union is in Geneva, Switzerland.

\section{Membership}

3.1. The members of the Union are its Adhering Bodies.

$3 \cdot 2$. There shall be only one member for each Country.

3.3. In a Country the Adhering Body can be a National Academy, National Research Council or similar body, or a scientific society or group of such societies. Each Adher- ing Body shall form a National Committee for Crystallography to represent it in the Union.

3.4. Any number of Countries may agree to form a group in order to name or establish a single Adhering Body. This Body shall form a joint National or Regional Committee for Crystallography. Wherever the terms Country and National Committee for Crystallography are used in these Statutes or in the By-Laws, they shall be taken to include such groups of Countries and joint National or Regional Committees for Crystallography.

3.5. Membership in the Union shall be fully effective when the nature of the Adhering Body and the membership of the National Committee have been reported to and accepted by the General Assembly. Any replacement of an Adhering Body is subject to the approval of the Executive Committee and acceptance by the General Assembly. Any major change in the nature of an Adhering Body shall be considered valid only after it has been reported to and accepted by the General Assembly.

3.6. Adherence to the Union shall be in one of five Categories I-V with corresponding voting powers and contributions as set out in Statutes 5.5 and 9.4. A Body applying for adherence to the Union shall specify in which Category it wishes to adhere; this choice of Category, or any desired change in the Category, is subject to the approval of the Executive Committee and confirmation by the General Assembly.

3.7. Any extension of a joint adherence formed in accordance with Statute 3.4 is subject to the approval of the Executive Cormmittee and acceptance by the General Assembly.

3.8. Participation in Special Projects [Statute 1.2(f)] shall not be obligatory. The extent of financial participation shall be a matter for special negotiation for each such project, except that the relationship between contribution and voting power within the project shall be that of the Category scheme defined in Statutes 5.5 and 9.4 to determine this relationship in the General Assembly.

3.9. Each National Committee has the right to submit to the Union through the General Secretary questions within the competence of the Union.

3.10. Any Adhering Body may withdraw from the Union if it has given notice of withdrawal at least six months before the end of the current financial year; it is required to fulfil its obligations relating to the time period when it was a member of the Union. Its membership and any further obligations shall then be suspended by the Executive Committee at the expiry of the notice of withdrawal. The withdrawal shall take effect when it has been reported to the General Assembly. 
3.11. An Adhering Body which withdraws from the Union in accordance with Statute $3 \cdot 10$, or any Adhering Body whose membership is cancelled in accordance with Statutes $5 \cdot 12$ or $9 \cdot 6$, loses all rights in connexion with the Union.

3.12. If the Countries of a group formed in accordance with Statute 3.4 agree that the group should be dissolved, or if a Country wishes to withdraw from such a group, with or without the agreement of the other Country or Countries of the group, the adherence of the original group shall be suspended by the Executive Committee at the expiry of an appropriate notice, provided that the original group has fulfilled its obligations. The termination of the original adherence shall take effect when the matter has been reported to the General Assembly. Pending this report, the Countries of the group, or any of them, may submit proposals for the continuation of their representation in the Union. In each of such proposals the nature of the Adhering Body, the membership of the National Committee and the desired Category of adherence shall be specified. These proposals are subject to the approval of the Executive Committee, which shall then make ad interim arrangements concerning these adherences. These arrangements are subject to acceptance by the General Assembly.

\section{Administration}

$4 \cdot 1$. The work of the Union shall be conducted by (a) the General Assembly;

(b) the Officers of the Union, constituting the Executive Committee;

(c) the Commissions as defined in Statute $8 \cdot 1$.

The composition and function of these bodies are defined in the following paragraphs, whose application is governed by the By-Laws.

\section{General Assembly}

$5 \cdot 1$. The work of the Union shall be directed by the General Assembly which is composed of delegates appointed by the Adhering Bodies.

5.2. The Executive Committee is responsible to the General Assembly and shall participate in its deliberations. Members of the Executive Committee have no voting power in the General Assembly, except for the casting vote of the Chairman [Statute 5.8].

$5 \cdot 3$. The General Assembly shall, as a rule, hold an ordinary meeting once every three years. The date and the place of the meeting, unless determined by the previous General Assembly, shall be determined by the Executive Committee. The General Secretary shall communicate the date and the place of the meeting to the National Committees and to the Commissions at least twelve months in advance.

5.4. In special cases, the President of the Union, with the consent of the Executive Committee, may call an extraordinary meeting of the General Assembly. He shall do so at the request of one-fifth of the Adhering Bodies. The routine business of a General Assembly prescribed in Statute $5 \cdot 10$ shall normally be omitted, unless specifically included in the agenda; but an extraordinary General Assembly shall have the same powers, and be subject to the same rules, as an ordinary General Assembly, except where otherwise is stated in the Statutes and By-Laws. The General Secretary shall communicate the date and the place of the extraordinary General Assembly to the National Committees and to the Commissions at least eight months in advance if amendment of the Statutes is contemplated, or at least four months otherwise.

5.5. The voting power of an Adhering Body at General Assemblies shall be in accordance with its Category of adherence, as follows

$\begin{array}{lccccc}\text { Category } & \text { I } & \text { II } & \text { III } & \text { IV } & \text { V } \\ \text { Number of votes } & 1 & 2 & 3 & 4 & 5\end{array}$

5.6. Each Adhering Body, through its National Committee, shall make known to the General Secretary before the opening of each General Assembly the names of its delegates (and of their alternates, if any), and also the name of the chairman of the national or regional delegation. No Officer of the Union may be a member of any delegation, nor shall any person serve as a member of more than one delegation.

$5 \cdot 7$. Normally each of the delegates present at a General Assembly shall have one vote only, but when for special reasons an Adhering Body cannot be fully represented at a General Assembly it may distribute its votes among a number of delegates smaller than the number of votes which that Adhering Body has in accordance with the Category in which it adheres; such a decision has to be made known to the General Secretary before the opening of the General Assembly concerned. Any Adhering Body not represented at a General Assembly may forward its views to the General Secretary by letter, and such views shall be made known to the General Assembly if received before voting takes place.

5.8. Except where otherwise provided in the Statutes and By-Laws, decisions of the General Assembly are taken by a majority of the votes cast. In the event of an equal division of votes the Chairman shall take the final decision.

5.9. No question which has not been placed on the agenda of business to be transacted at the General Assembly shall be discussed or put to the vote unless a proposal to that effect be approved by at least two-thirds of the votes there represented.

5·10. The General Assembly shall

(a) take appropriate action on any matters concerning membership in the Union [Statutes $3 \cdot 5,3 \cdot 6,3 \cdot 7,3 \cdot 10$, $3 \cdot 12$ and $5 \cdot 12$ ];

(b) elect the President, the Vice-President, the General Secretary, the Treasurer and the other Officers of the Union [Statutes 6.1 and 6.3];

(c) consider, and make decisions regarding, the confirmation of the appointments of Editors of publications of the Union [Statute $7 \cdot 1$ ];

(d) determine the number of elected members of each Commission set up by the General Assembly [Statutes $5 \cdot 11(\mathrm{c})$ and $8 \cdot 2]$

(e) elect the Chairmen and members of the Commissions [Statute 8.2];

$(f)$ elect representatives of the Union on Joint Commissions with other Unions, and on other scientific bodies [Statutes $1 \cdot 2(g)$ and $8 \cdot 5$ ];

$(g)$ receive the reports on the activities of the Union and of its Commissions [Statutes 6.8 and 8.4];

(h) receive the audited accounts for the years elapsed since the previous General Assembly [Statute 9·1];

(i) on receipt of satisfactory reports or accounts, release the Treasurer, or any other Officer, or the Chairman or any member of any Commission or other body, from financial or other liability to the Union;

(j) determine the budget for general expenditure for the period to the next General Assembly, on the basis of 
the estimate prepared by the Executive Committee [Statutes 9.2 and 9.3 ];

(k) determine the unit contribution for the period to the next General Assembly [Statute 9.5];

(l) determine the general policy and the time table for the period to the next General Assembly;

(m) give preliminary consideration to the activities of the Union for the three-year period following the next General Assembly.

5.11. The General Assembly shall have the power

(a) to amend these Statutes in accordance with Statute $13 \cdot 1$

(b) to formulate and amend By-Laws on any matters not covered by these Statutes;

(c) to set up any Commission or other body it may deem necessary for the administrative and scientific work of the Union, and to determine the terms of reference of such body [Statute $1 \cdot 2(d)$ ];

(d) to dissolve any Commission or other body set up in accordance with Statute $5 \cdot 11(c)$ when its existence is deemed no longer necessary;

(e) to determine the nature of Special Projects which shall be financed independently of the regular operations of the Union [Statute 1.2(f)];

$(f)$ to decide on all other questions falling within the competence of the Union.

5.12. The General Assembly may cancel the membership of any Adhering Body of the Union for any serious cause; such a decision may only be taken after the member in question has been previously given an opportunity to furnish an explanation to the Executive Committee for forwarding to the General Assembly. At least three-fourths of the total number of the votes of all Adhering Bodies are required for cancellation.

\section{Executive Committee}

$6 \cdot 1$. The officers of the Union constituting the Executive Committee are

(a) the President;

(b) the Vice-President;

(c) the General Secretary;

(d) the Treasurer;

(e) the immediate Past President;

(f) six ordinary members.

6.2. The election of Officers of the Union shall be arranged in such a way that there will not be more than two Officers from any one Country. A person is regarded as belonging to the Country in which he is normally resident and where he conducts the main part of his work. In cases of doubt the General Assembly shall decide to which Country a person is considered to belong.

If during the period between General Assemblies the number of Officers from a Country is increased above two because of any change of Country of residence, the Officer or Officers who changed his or their Country of residence may continue his or their service until the close of the next General Assembly. If at that time the number of Officers from the Country concerned would remain above two, one or more of the Officers who changed his or their Country of residence shall be considered to have resigned.

6.3. The offices of General Secretary and Treasurer may be combined and shall then be considered as a single office. Otherwise no person shall hold more than one office simultaneously. The voting power of the Officer holding the combined office of General Secretary and Treasurer shall not be more than that of either the General Secretary or the Treasurer.

6.4. The President holds office as President until the close of the ordinary General Assembly following his election, and continues as a member of the Executive Committee until the close of the ordinary General Assembly next but one following that of his election. He is not then eligible for immediate re-election to the office of President, nor to any other office in the Executive Committee.

The Vice-President holds office until the close of the ordinary General Assembly following his election. He is not eligible for immediate re-election to the same office.

The General Secretary and the Treasurer hold office until the close of the ordinary General Assembly following that of their election. They are eligible for immediate re-election to the same office, but shall not serve in that office for more than three full consecutive terms.

Three ordinary members are elected at each ordinary General Assembly and hold office until the close of the ordinary General Assembly next but one following that of their election. They are not eligible for immediate re-election to the same office.

In the event of a vacancy, through resignation, death or other cause, any Officer elected by the General Assembly to fill the unexpired term of office shall serve only to the end of the normal term of the Officer he replaces; at the end of this service he may be nominated for re-election for a full term to the same office.

6.5. The Executive Committee shall carry out the decisions of the General Assembly and give effect to the general policy of the Union as determined by the General Assembly.

6.6. During the periods between General Assemblies the Executive Committee shall have full power to carry on the business of the Union in all matters not specifically assigned by the Statutes, the By-Laws or the General Assembly to individuals or to Commissions or other bodies. If necessary, it may make ad interim arrangements in all matters assigned by the Statutes and By-Laws to the General Assembly.

6.7. In the event of an individual, a Commission or another body of the Union failing to act in any matter assigned to him or it by the Statutes, By-Laws or the General Assembly, the Executive Committee may, after reasonable notice to the individual or body in question, take action on behalf of the Union.

6.8. The Executive Committee shall report on its activities to the General Assembly. The action taken by the Executive Committee in accordance with Statutes $3 \cdot 5,3 \cdot 6$, $3 \cdot 7,3 \cdot 10,3 \cdot 12,6 \cdot 6,6 \cdot 7,7 \cdot 1,7 \cdot 2,8 \cdot 2,9 \cdot 6$ and $9 \cdot 9$ shall be included in this report. The report to the General Assembly shall be dispatched by the General Secretary to the National Committees and to the Commissions at least ten weeks before the meeting.

\section{Publications of the Union}

$7 \cdot 1$. The Editors of the publications of the Union are appointed by the Executive Committee for initial terms extending through not more than six years beyond the ordinary General Assembly following the appointment. Each initial appointment is subject to confirmation by that General Assembly. Reappointments may be made by the Executive Committee for terms of not more than three years, and are subject to confirmation by the ordinary General Assembly following the reappointment. 
7·2. Co-editors and Assistant Editors are appointed by the Editors for terms of not more than three years, but they may be reappointed immediately for terms of the same length. The appointments and reappointments are subject to the approval of the Executive Committee.

7.3. Editors and Co-editors are members of the Commissions set up for their respective publications.

\section{Commissions and Joint Commissions}

$8 \cdot 1$. The term 'Commission' shall be understood to include all Commissions, Committees, and other bodies of the Union with the exception of National Committees for Crystallography, and the Executive Committee and its subcommittees.

8.2. The Chairmen and members of the Commissions are elected at each General Assembly. Subject to the approval of the Executive Committee, Commissions may coopt further members during the periods between General Assemblies, and may fill vacancies arising from resignation, death or other cause. Members (but not Chairmen) may be nationals of or residents in a Country not adhering to the Union.

8.3. The Commissions shall be responsible to the General Assembly. They shall generally have full freedom in arranging their internal structure and work. They may formulate their own Rules of Procedure within the framework of the Statutes and By-Laws of the Union, and within their terms of reference.

8.4. The Chairmen shall report on the activities of the Commissions to the General Assembly. These reports shall reach the General Secretary at least fourteen weeks before the General Assembly and shall be dispatched by him to the National Committees and the Commissions at least ten weeks before the meeting.

$8 \cdot 5$. The representatives of the Union on Joint Commissions and on other scientific bodies [Statute $1 \cdot 2(\mathrm{~g})$ ] are elected at each General Assembly. For each such body one representative shall be designated as the chief representative of the Union. His obligations to report are the same as those of the Chairmen of the Commissions.

\section{Finance}

9.1. The Executive Committee shall be responsible to the General Assembly for all the financial affairs of the Union.

9.2. The Chairman of each Commission (or other member approved by the Executive Committee) shall be responsible to the Executive Committee for any expenditure of funds by his Commission. Five months before each General Assembly he shall submit to the Executive Committee an estimate of the budget of his Commission for the period between that General Assembly and the one following it. He shall submit annually to the Executive Committee a revised budget for the ensuing year and a statement of accounts for the preceding year. His accounts shall be available for audit by the Executive Committee or its appointees.

9.3. The Executive Committee shall prepare an estimate of the budget for the period between the next General Assembly and that following it. This estimate shall be dispatched by the General Secretary to the National Committees and to the Commissions at least ten weeks before the meeting.

9.4. Each Adhering Body shall pay an annual subscription in accordance with its Category of adherence, as follows

$\begin{array}{lccccc}\text { Category } & \text { I } & \text { II } & \text { III } & \text { IV } & \text { V } \\ \text { Number of unit contributions } & 1 & 3 & 6 & 10 & 15\end{array}$

The annual subscriptions are payable during the calendar year to which they apply.

$9 \cdot 5$. The unit contribution, stated in terms of a currency to be designated by the Executive Committee, shall be determined by the General Assembly for the period to the next General Assembly.

9.6. Any Adhering Body which is in arrears with its subscription for two years shall be warned and shall be deprived of its voting power. The membership of any Adhering Body which is in arrears for four years shall be automatically suspended and may be cancelled by the General Assembly under Statute 5:12. An Adhering Body whose membership has been suspended shall receive no privileges of the Union and incur no further responsibility for dues; it may be reinstated by action of the Executive Committee.

9.7. The financing and management of publications of the Union shall be kept distinct from general expenditure. Editors and Co-editors shall be responsible to the Executive Committee for any receipts or expenditure of funds by them with respect to their publications.

$9 \cdot 8$. The financing and management of Special Projects of the Union shall be kept distinct from the regular operations of the Union.

9.9. No funds may be solicited or accepted on behalf of the Union or any of its Commissions from any international, governmental or other agency or person without the prior approval of the Executive Committee. Any $\mathrm{Na}$ tional Committee for Crystallography may however solicit funds within its own Country for the support of its own activities or in its capacity as host for a General Assembly, Congress or other meeting sponsored by the Union. Any funds in the form of donations, legacies, or grants, accepted by the Executive Committee shall be used so far as is possible in accordance with the wishes of the donors.

\section{Liability}

$10 \cdot 1$. The Union is liable only to the extent of its assets, and the Adhering Bodies are not individually liable for its corporate debts and liabilities.

10.2. The liabilities of the Adhering Bodies are limited to the payment of their annual subscriptions and to such contributions to the Special Projects of the Union as they may have pledged.

10.3. No Officer of the Union shall be individually liable for the corporate debts and liabilities of the Union. The Union shall indemnify any Officer or former Officer in respect of any claims laid against him in respect to his authorized actions on behalf of the Union. At its discretion the Executive Committee may extend this indemnity to other persons in respect of their authorized actions on behalf of the Union.

10.4. The Union shall not accept any liability for any personal loss, damage or accident sustained by any individual, not being an employee of the Union, engaged in any activity, including travel, on behalf of the Union.

\section{Auditor and Representation of the Union}

11-1. The Auditor of the Union shall be a person or corporation authorized to act as a public accountant. The Auditor shall be appointed by the Executive Committee on the recommendation of the Treasurer and maintained 
thereafter subject to the approval of the General Assembly.

$11 \cdot 2$. With the exception of cheques, all contracts and formal agreements involving the Union shall be signed by two Officers of the Union. The Executive Committee may restrict the power to sign a particular document or type of document to specific persons among the Officers; and it shall determine rules for the signing of cheques.

11.3. The President shall be the official representative of the Union on all other civil and legal occasions and in dealing with other organizations. He may in this respect delegate his powers to another Officer of the Union, or, with approval of the Executive Committee, to any other person.

\section{Dissolution of the Union}

12.1. The Union shall not be dissolved except on a motion presented at a General Assembly. If a motion to dissolve is to be presented, the notice for that General Assembly as given under Statute $5 \cdot 3$ or $5 \cdot 4$ shall include a statement of the motion to dissolve and shall refer specifically to this Statute. Such a motion shall be presented to the General Assembly without amendment and at least three-fourths of the votes there represented shall be required for dissolution.

In the event that less than three-fourths of the total number of the votes of all Adhering Bodies are represented at the General Assembly, a postal ballot may be arranged, and in such a postal ballot at least three-fourths of the total number of the votes of all Adhering Bodies shall be required for dissolution.

12.2 . In the event of dissolution of the Unjon in accordance with Statute $12 \cdot 1$, the General Assembly shall appoint a special Committee, reporting to the International Council of Scientific Unions, for the liquidation of the as- sets of the Union. The nett assets shall be given to one or more, preferably international, organizations or insitutions which shall spend the assets for purposes so far as is possible in accordance with the objects of the Union.

\section{Statutes}

13.1. Amendments to the Statutes require action at a General Assembly. An amendment is adopted at such an Assembly only if (i) at least two-thirds of the votes represented at the General Assembly are affirmative and (ii) if these affirmative votes amount to more than half the total number of the votes of all Adhering Bodies. In the event that the vote on a proposed amendment satisfies condition (i) but not condition (ii), the Executive Committee may refer the proposed amendment to a postal ballot of the Adhering Bodies. If the proposed amendment then obtains affirmative votes amounting to more than half the total number of the votes of all Adhering Bodies, the amendment is adopted.

Proposals for amendments may be made by the Executive Committee or by any National Committee. Such proposals made by National Committees shall reach the General Secretary at least six months in advance of the General Assembly. The General Secretary shall dispatch these proposals, and those made by the Executive Committee, to the National Committees and to the Commissions at least four months before the meeting.

13.2. The present English text shall be considered the authoritative text in the interpretation of these Statutes. Where disputes arise concerning this interpretation, the matter shall be decided by the General Assembly, or, during the periods between General Assemblies, by a ruling of the President of the Union.

\section{By-Laws}

\section{General Assembly}

$1 \cdot 1$. The agenda of business to be transacted at a General Assembly shall be determined by the Executive Committee and shall be dispatched by the General Secretary to the National Committees and to the Commissions at least ten weeks before the meeting.

1.2. Any National Committee and any Commission of the Union may propose business to be transacted at a General Assembly. Such proposals shall reach the General Secretary at least four months before the meeting, and shall be included in the agenda of the General Assembly.

1.3. Chairmen of the National Committees and of the Commissions may attend the General Assembly and take part in the discussions but shall have no voting power. The President may invite representatives of scientific bodies, or individuals, to attend the General Assembly; such invited guests may take part in the discussions but shall have no voting power. Other interested persons may also attend the General Assembly but they shall not take part in the discussions, unless specifically invited or permitted to do so by the Chairman, and they shall have no voting power.

At the discretion of the Chairman any or all of the persons attending the General Assembly under this By-Law may be required to withdraw.

1.4. If a delegate to a General Assembly is absent from a session of the Assembly, his place may be taken by any of the alternates nominated to the Assembly under Statute 5.6 provided that the Secretary of the Assembly is notified before the beginning of the session of the name of the delegate and of the name of the alternate, either by the delegate or by the chairman of his delegation. In general no such substitution may take place during a session of the Assembly, but the Chairman of the Assembiy may permit substitution to be made under special circumstances.

1.5. The names of the representatives of a Body whose application for adherence to the Union has been received and declared in good order by the Executive Committee under By-Law 2.9(a), shall be made known to the General Secretary as prescribed in Statute $5 \cdot 6$. These representatives shall be seated with the delegates of the Adhering Bodies during the preliminary ceremonies and initial business of the General Assembly. At the discretion of the Chairman or by a vote of the Assembly, the representatives may be required to withdraw during the discussion of and voting on matters concerning adherence to the Union. The delegates of a new member may take their seats among the other delegates as soon as the General Assembly has accepted their Adhering Body as a member of the Union.

1.6. Unless decided otherwise by the General Assembly, matters concerning adherence to the Union shall take precedence over all other business at the first business session 
of the General Assembly, and shall normally precede the reading of the minutes and the discussions of matters arising therefrom.

1.7. Delegates of an Adhering Body may not vote on any matter concerning its membership in the Union.

1.8. In the event of the General Assembly considering a change in a group of Countries according to Statute 3.12, the delegates from the Countries belonging or previously belonging to the group may not vote on any matters concerning the representation in the Union of any of these Countries. After acceptance of the ad interim arrangements made by the Executive Committee under Statute 3.12, these delegates have full voting power.

1.9. The delegates of new members may not vote on any matters concerning adherence to the Union, nor on any matters concerning the adoption of the minutes of the previous General Assembly, during the General Assembly at which they themselves are admitted.

$1 \cdot 10$. The General Secretary shall post on the official bulletin board of the General Assembly the names of the Chairmen and members (and alternates, if any) of the delegations and the numbers of votes represented by them.

1.11. During the General Assembly any delegate (or alternate) and any Officer of the Union is considered to have been notified of any action of the General Assembly, or of the Executive Committee, or of any Commission, if one of the two following procedures is adopted

(a) a notice is placed in the mail box or other location at which the delegate (or alternate) or the Officer is accustomed to receive his mail during the course of the General Assembly, or

(b) a notice is handed to the designated Chairman of each delegation with the specific request that he communicate its contents to his delegation, and to the General Secretary with the specific request that he communicate its contents to the Executive Committee,

provided that in either case a similar notice is posted on the official bulletin board.

1.12. Minutes of the meetings of the General Assembly shall be made. Copies of the draft minutes shall be communicated by the General Secretary to the National Committees, to the Officers of the Union and to the Chairmen of its Commissions. After approval at a subsequent General Assembly, two copies of the definitive minutes shall be signed by the Chairman and the Secretary of the session at which they are approved, and shall be kept by the President and the General Secretary.

\section{Executive Committee}

$2 \cdot 1$. The Executive Committee shall meet at each General Assembly. There shall be at least two additional meetings during the period between General Assemblies, unless the Executive Committee by a postal vote decides otherwise.

2.2. The Executive Committee shall make nominations to the General Assembly for the Officers of the Union, for the Chairmen and members of the Commissions, and for representatives on Joint Commissions and on other scientific bodies. In each case in which an Officer of the Union is nominated for another office, either by the Executive Committee or by delegates to the General Assembly [By-
Law 7.2], the Executive Committee shall also include a nomination for the office which would be vacated if the election to the other office occurs. If the election to the other office does not occur and if the Officer's term has not expired, the nomination to the office which would have been vacated shall not be considered.

$2 \cdot 3$. In the event of the resignation, death or disability of the President, the Vice-President shall assume the office of President until the close of the next ordinary General Assembly.

In the event of the resignation, death or disability of the Vice-President, the Executive Committee may appoint one of its members to serve as Vice-President until the close of the next ordinary General Assembly.

In the event of such circumstances that the General Secretary or the Treasurer cannot carry out his duties, the other shall assume those duties until the Executive Committee has considered the situation. In that event the Executive Committee may, but need not, appoint a new General Secretary or Treasurer to serve until the close of the next ordinary General Assembly.

In the event of the resignation, death or disability of an ordinary member of the Executive Committee, the Executive Committee may co-opt a new member to serve until the close of the next ordinary General Assembly.

The accession. of an Officer of the Union to a new office under the conditions of this By-Law shall be accompanied by his resignation from the office to which he was previously elected, but service under this By-Law shall not affect his eligibility for immediate re-election to the new office.

2.4. Any Officer unable to attend a meeting of the Executive Committee may designate a deputy to attend that meeting. Such a deputy shall be named in writing to the President or the General Secretary. He shall have no voting power and shall not be counted as part of a quorum.

2.5. The President, on his own initiative or at the request of the Executive Committee, may invite any individual to be present at a meeting of the Executive Committee; such an invited guest may take part in the discussions but shall have no voting power.

2.6. At a meeting of the Executive Committee two-thirds (fractional parts neglected) of the Officers specified by Statutes $6 \cdot 1$ and $6 \cdot 3$, excluding any who have resigned or died, shall constitute a quorum; and decisions shall be taken by a simple majority of the Officers present and voting. The Chairman of the meeting shall not vote in open ballots; but in the event of an equal divison of votes the Chairman may take the final decision. In secret ballots required by the Statutes or By-Laws or ordered by the Chairman he may vote at his discretion. If he does not vote and there is an equal division of votes he may take the final decision. If he has vited in a secret ballot he may not take the final decision, and must leave it to further discussion and ballot.

2.7. During the period between meetings of the Executive Committee, voting may take place by post. Adoption of a proposal shall require affirmative votes from two-thirds (fractional parts neglected) of the Officers specified by Statutes 6.1 and 6.3 , excluding any who have resigned or died. No decision on any proposal other than calling or cancelling a meeting of the Executive Committee shall be made by postal vote in the event that at least two Officers express the wish that the matter concerned should first be given more or further consideration, either by correspondence or at a meeting of the Executive Committee. 
2.8. Minutes of the meetings of the Executive Committee shall be made. Two copies of the minutes shall be signed by the Chairman and the Secretary of the meeting at which they are approved, and shall be kept by the President and the General Secretary. A summary of the draft minutes of meetings of the Executive Committee shall be despatched by the General Secretary to the National Committees within ten weeks of the conclusion of each meeting.

2.9. In addition to the obligations described in the Statutes and elsewhere in these By-Laws, the Executive Committee shall

(a) receive and report on applications for adherence to the Union if the nature of the applying Body and the membership of the National Committee have been duly reported to and considered to be in good order by the Executive Committee; pending the next General Assembly the Executive Committee may in the case of case of such applications provide such services of the Union as it deems proper;

(b) consider and report on any other questions concerning adherence to the Union;

(c) present an annual report, including an audited statement of receipts and expenditure, to the National Committees;

(d) report to the Commercial Registry of Geneva any changes in the registered information concerning the Union.

(e) have the power to appoint representatives on scientific bodies not belonging to the Union.

\section{President}

$3 \cdot 1$. The President of the Union is Chairman of the General Assembly and of the Executive Committee. In the absence of the President from a session or meeting, the Vice-President, or if he is not present another Officer of the Union designated by the Executive Committee, shall act as Chairman.

3.2. The President of the Union is an ex officio member, with voting power, of all Commissions of the Union.

\section{General Secretary}

4.1. The General Secretary of the Union is Secretary of the General Assembly and of the Executive Committee. In his absence from a session or meeting, another Officer of the Union designated by the Executive Committee shall act as Secretary.

$4 \cdot 2$. The General Secretary of the Union is an ex officio member, with voting power, of all Commissions of the Union.

4.3. The General Secretary is responsible for conducting the ordinary business of the Union, with the exception of the financial administration, and for keeping its records.

\section{Treasurer}

5.1. The Treasurer of the Union is responsible for the financial administration of the Union and for keeping its accounts.

5-2. The Treasurer is an ex officio member of all Commissions of the Union, with voting power only for those questions which may involve the Union in financial commitments.

\section{Commissions of the Union}

6.1. The Chairmen of the Commissions and the chief representatives on Joint Commissions or other bodies shall forward records of all meetings of the Commissions to the President and the General Secretary. They shall report annually on the activities of these bodies to the Executive Committee.

6.2. If funds are provided for the use of a Commission, it may make its own financial arrangements, with the prior approval of the Executive Committee and subject to the provisions of the Statutes and By-Laws. In cases where the Executive Committee has given prior approval, payments toward travelling expenses of Chairmen and members of Commissions may be made from the general funds of the Union.

6.3. No person who has served for three consecutive full terms of office on a Commission is eligible for nomination for a fourth consecutive term of service on the same Commission except as Chairman. In no case is any person eligible for more than four consecutive full terms of service on the same Commission. These limitations do not apply to Editors [Statute 7-1], Co-editors [Statute 7.2] and ex officio members. Any Commission, in its Rules of Procedure, may reduce the length of service specified here.

6.4 . In the event of the resignation, death or disability of the Chairman of any Commission, the Executive Committee shall appoint a member of that Commission to serve as Chairman until the close of the General Assembly following this appointment.

\section{Nominations and Elections}

$7 \cdot 1$. All delegates (and alternates) shall be notified of the nominations presented by the Executive Committee under By-Law 2.2 for the Officers of the Union at least ninety-six hours before the scheduled commencement of the session of the General Assembly at which the vote is to be taken.

$7 \cdot 2$. After the delegates have been notified of the nominations by the Executive Committee as prescribed in By-Law $7 \cdot 1$, other nominations for Officers of the Union may be made by any six or more delegates. Such nominations shall be made in writing to the General Secretary not less than forty-eight hours before the voting session and shall be accompanied by a written statement that the consent of the nominees has been obtained. These nominations shall be posted by the General Secretary on the officia! bulletin board not less than thirty-six hours before that session.

7.3. Recommendations from each Commission for the Chairman and members of the Commission shall be made in writing to the General Secretary not less than seventytwo hours before the voting session of the General Assembly. These recommendations shall be approved by a majority of the members of the Commission and shall be accompanied by a written statement that the consent of the persons recommended has been obtained. All delegates (and alternates) shall be notified of the nominations presented by the Executive Committee under By-Law 2-2 for the Chairman and members of each Commission at least forty-eight hours before the voting session.

7.4. After the delegates have been notified of the nominations by the Executive Committee as prescribed in By-Law $7 \cdot 3$, other nominations for the Chairman and members of each Commission may be made by any six or more delegates. Such nominations shall be made in writing to the General 
Secretary not less than twenty-four hours before the voting session and shall be accompanied by a written statement that the consent of the nominees has been obtained. These nominations shall be posted by the General Secretary on the official bulletin board not less than twelve hours before that session.

7.5. In voting for the President, Vice-President, General Secretary and Treasurer of the Union, each of these offices shall be taken separately and voting shall be by secret ballot. A simple majority of the votes represented by the delegates present at the voting session shall be required for election. If there is only one candidate for one of these offices, his nomination shall be presented to the General Assembly and the candidate concerned shall be considered as elected. If there are two candidates or more, and an election is not achieved after two ballots, the candidate receiving the smallest number of votes in the second ballot shall be removed from the list. If an election is not achieved after a third ballot, this procedure shall be repeated until an election is achieved. Any ballot form showing more than one mark shall be invalid. Any contingency arising during the balloting shall be resolved by a ruling of the Chairman of the General Assembly.

$7 \cdot 6$. The election of the ordinary members of the Executive Committee shall be by secret ballot, the ballot form showing the nominations presented by the Executive Committee and the nominations made by delegates. A simple majority of the votes represented by delegates present at the voting session shall be required for election. If there are not more candidates than vacancies, the nominations shall be presented to the General Assembly and the candidates shall be considered as elected. If there are more candidates than vacancies and all vacancies are not filled by election at the first ballot, a second ballot shall be arranged containing the names of the candidates not elected. If there are vacancies after the second ballot, the balloting procedure shall be repeated until all vacancies are filled; for each of these subsequent ballots the name of the candidate receiving the smallest number of votes on the preceding ballot shall be removed from the list. Any ballot form showing more marks than the appropriate number of va- cancies shall be invalid. Any contingency arising during the balloting shall be resolved by a ruling of the Chairman of the General Assembly.

7.7. In voting for the Chairmen and members of the Commissions each Commission shall be considered separately. For the election of the Chairmen the procedure described in By-Law 7.5 shall be followed. For the election of the members of the Commissions the procedure described in By-Law 7.6 shall be followed except that no more than two ballots shall be held. Any vacancies still remaining may be filled as provided in Statute $8 \cdot 2$.

$7 \cdot 8$. The procedure for the nomination and election of representatives of the Union on Joint Commissions and on other scientific bodies is so far as is possible the same as that for the nomination and election of the Chairmen and members of the Commissions.

\section{By-Laws}

8.1. These By-Laws may be amended or suspended at any General Assembly and at least two-thirds of the votes there represented are required for an amendment or suspension. A motion to amend or suspend, if not already included in the agenda of business of the General Assembly, may be placed there by the procedure of Statute 5.9. No notice is required for a proposal to suspend the time limits prescribed by By-Laws $7 \cdot 2$ and 7.4. Notification of any other motion to amend or suspend the By-Laws must be given by its originators to all delegates (and alternates) and to all Officers of the Union in accordance with the procedure prescribed in By-Law 1.11, at least forty-eight hours before the session of the General Assembly at which the motion is to be considered.

$8 \cdot 2$. Words importing the male sex in the Statutes and By-Laws shall include the female sex.

8.3. The present English text shall be considered the authoritative text in the interpretation of these By-Laws. Where disputes arise concerning this interpretation, the matter shall be decided by the General Assembly, or during the periods between General Assemblies, by a ruling of the President of the Union. 


\section{APPENDIX}

Time Table in Preparation for General,Assembly

12 months Notice of date and place of ordinary General Assembly to National Committees and Commissions

8 months Notice of date and place of extraordinary General Assembly to National Committees and Commissions, if amendment of Statutes is contemplated

6 months

5 months

4 months

4 months

Proposals for amendments to Statutes to General Secretary

Estimated budgets from Commissions to Executive Committee

Proposals for agenda of General Assembly to General Secretary

Notice of date and place of extraordinary General Assembly to National Committees and Commissions, if amendment of Statutes is not contemplated

4 months

14 weeks

10 weeks

10 weeks

10 weeks

10 weeks

Proposals for amendments to Statutes to National Committees and Commissions

Reports of Commissions to General Secretary

Report of Executive Committee to National Committees and Commissions

Reports of Commissions to National Committees and Commissions

Budget to National Committees and Commissions

Agenda to National Committees and Commissions

$\begin{array}{rc}\text { Statute } & \text { By-Law } \\ 5.3 & - \\ 5 \cdot 4 & - \\ 13 \cdot 1 & - \\ 9.2 & - \\ - & 1 \cdot 2 \\ 5.4 & - \\ 13 \cdot 1 & - \\ 8.4 & - \\ 6.8 & - \\ 8.4 & - \\ 9.3 & - \\ - & 1 \cdot 1\end{array}$

\section{Time Table during General Assembly}

'Before'

Notice by National Committees to General Secretary of names of delegates, alternates and chairmen of delegations, and of distribution of votes if not one per delegate

96 hours

72 hours

Nominations by Executive Committee for Officers of Union

Recommendations by Commissions to General Secretary for Chairmen and members of Commissions

48 hours

48 hours

Notice to General Secretary of nominations by delegates for Officers of Union

48 hours

Nominations by Executive Committee for Chairmen and members of Commissions

Notification of motion to amend or suspend By-Laws

36 hours

24 hours

Posting of nominations by delegates for Officers of Union

Notice to General Secretary of nominations by delegates for Chairmen and members of Commissions

12 hours

Posting of nominations by delegates for Chairmen and members of Commissions

$\begin{array}{cc}5 \cdot 6.5 \cdot 7 & - \\ - & 7 \cdot 1 \\ - & 7 \cdot 3 \\ - & 7 \cdot 2 \\ - & 7 \cdot 3 \\ - & 8 \cdot 1 \\ - & 7 \cdot 2 \\ - & 7 \cdot 4 \\ - & 7 \cdot 4\end{array}$




\title{
ANNEX III \\ Membership of Committees, Commissions, etc., \\ as at 1 May 1976
}

\author{
Membership of Bodies belonging to the Union
}

EXECUTIVE COMMITTEE

\section{President}

A. Magnéli*

Arrhenius Laboratory, University of Stockholm, S-104 05 Stockholm, Sweden

Vice-President

B. K. Vainshtein* (USSR).

General Secretary and Treasurer

S. E. Rasmussen*

Department of Chemistry,

Aarhus University,

DK-8000 Aarhus C, Denmark

Immediate Past President

Dorothy Hodgkin* (U.K.)

Ordinary Members

F. R. Ahmed $\dagger$ (Canada)

E. F. Bertaut $\dagger$ (France)

K. Kuchitsu* (Japan)

K. Lukaszewicz* (Poland)

S. Ramaseshant (India)

D. P. Shoemaker* (U.S.A.)

Executive Secretary

J. N. King,

International Union of Crystallography, 13 White Friars, Chester CH1 1NZ, England

COMMISSION ON JOURNALS

Chairman and Editor of Acta

Crystallographica

A. J. C. Wilson

Department of Physics,

University of Birmingham,

P.O. Box 363, Birmingham

B15 2TT, England

Co-chairman and Editor of Journal of Applied Crystallography

R. A. Young, School of Physics and Engineering Experiment Station, Georgia Institute of Technology, Atlanta, Georgia 30332, U.S.A.

* Until the close of the Eleventh General Assembly (1978).

+ Until the close of the Twelfth General Assembly (1981).

\pm Nominated by the Executive Committee to fill the vacancy created by the election of A. Magnéli as President.
F. R. Ahmed (Canada; Acta)

G. Allegra (Italy; $A$ cta)

H. Bärnighausen (B.R.D.; Acta)

J. B. Cohen (U.S.A.; $J A C$ )

J. M. Cowley (U.S.A.; Acta)

M. Hart (U.K.; JAC)

G. A. Jeffrey (U.S.A.; Acta)

J. C. Joubert (France, $J A C$ ) (as from 1 April 1976)

E. C. Lingafelter (U.S.A.; Acta)

H. Lipson (U.K.; Acta)

Z. G. Pinsker (USSR; $A c t a$ )

S. Takagi (Japan; Acta)

P. J. Wheatley (U.K.; Acta)

D. Watanabe (Japan; $J A C$ ) (as from 1 March 1976)

P. M. de Wolff (Netherlands; $J A C$ )

J. Wyart (France; Acta)

Book-review Editor

J. H. Robertson (U.K.; Acta and $J A C$ )

COMMISSION ON STRUCTURE REPORTS

Chairman and Editor

J. Trotter

Department of Chemistry, University of British Columbia, 2075 Wesbrook Place,

Vancouver, Canada V6T 1W5

Co-editors

L. D. Calvert (Canada)

G. Ferguson (Canada)

J. Iball (U.K.)

W. B. Pearson (Canada)

Clara B. Shoemaker (U.S.A.)

N. G. Vannerberg (Sweden)

Ex officio member

D. G. Watson (U.K.) (as Chairman of the Commission on Crystallographic Data)

COMMISSION ON INTERNATIONAL TABLES

\section{Chairman and Editor}

Th. Hahn

Institut für Kristallographie der Technische Hochschule, Templergraben 55, Aachen, B.R.D.

Co-editors

H. G. A. Arnold (B.R.D.)

E. Ascher (Switzerland)

E. F. Bertaut (France)

M. J. Buerger (U.S.A.)

D. W. J. Cruickshank (U.K.)

J. D. H. Donnay (Canada)
E. Hellner (B.R.D.)

W. T. Holser (U.S.A.)

J. A. Ibers (U.S.A.)

A. G. M. Janner (Netherlands)

V. A. Koptsik (USSR)

D. P. Shoemaker (U.S.A.)

A. Vos (Netherlands)

H. Wondratschek (B.R.D.)

COMMISSION ON CHARGE, SPIN AND MOMENTUM DENSITIES

Chairman

E. F. Bertaut

Laboratoire des Rayons X,

B. P. 166, Centre de Tri,

38042 Grenoble Cedex, France

Elected members

R. A. Bonham (U.S.A.)

P. J. Brown (France)

M. J. Cooper (U.K.) (Secretary)

P. Coppens (U.S.A.)

R. Hosemann (B.R.D.)

N. Kato (Japan)

K. V. J. Kurki-Suonio (Finland)

E. N. Maslen (Australia)

R. M. Moon (U.S.A.)

N. N. Sirota (USSR)

V. H. Smith (Canada)

Ex officio member

A. F. Andresen (Norway) (as Chairman of the Commission on Neutron Diffraction)

COMMISSION ON CRYSTAL GROWTH

Chairman

A. Authier

Laboratoire de Minéralogie-

Cristallographie, Université de

Paris VI, Tour 16,4 place Jussieu, 75230 Paris Cedex 05, France

Elected members

K. S. Bagdasarov (USSR)

E. Kaldis (Switzerland)

N. Kato (Japan)

P. Krishna (India)

K. Nassau (U.S.A.)

H. Peibst (D.D.R.)

I. Sunagawa (Japan)

Ex officio members

C. S. Sahagian (U.S.A.) (representative of the International Organization for Crystal Growth)

R. A. Young (U.S.A.) (as Editor of Journal of Applied Crystallography) 
COMMISSION ON CRYSTALLOGRAPHIC APPARATUS

\section{Chairman}

R. Rudman

Department of Chemistry, Adelphi University, Garden City, New York 11530, U.S.A.

\section{Elected members}

S. Abrahamsson (Sweden)

M. Colapietro (Italy)

R. W. Hendricks (U.S.A.)

S. Hosoya (Japan)

V. G. Lutsau (USSR)

S. Ramaseshan (India)

S. Suortti (Finland)

\section{COMMISSION ON CRYSTALLOGRAPHIC} COMPUTING

Chairman

G. C. Bassi

Départment de Recherches Fondamentales CPN, Centre d'Etudes Nucléaires de Grenoble, B. P. No. 85, 38041 Grenoble Cedex, France

\section{Elected members}

T. Ashida (Japan)

R. Diamond (U.K.)

S. R. Hall (Australia)

K. Huml (Czechoslovakia)

A. C. Larson (U.S.A.)

V. I. Simonov (USSR)

J. M. Stewart (U.S.A.)

Ex officio member

D. G. Watson (U.K.) (as Chairman of the Commission on Crystallographic Data)

COMMISSION ON CRYSTALLOGRAPHC DATA

Chairman

D. G. Watson

University Chemical Laboratory, Lensfield Road, Cambridge CB2 1EW, England

\section{Elected members}

R. Allmann (B.R.D.)

G. Bergerhoff (B.R.D.)

I. D. Brown (Canada)

G. G. Johnson Jr (U.S.A.)

A. D. Mighell (U.S.A.)

M. Nardelli (Italy)
E. Parthé (Switzerland)

N. L. Smirnova (USSR)

Ex officio members

G. C. Bassi (France) (as Chairman of the Commission on Crystallographic Computing)

J. Trotter (Canada) (as Chairman of the Commision on Structure Reports)

A. J. C. Wilson (U.K.) (as Chairman of the Commission on Journals)

COMMISSION ON CRYSTALLOGRAPHIC NOMENCLATURE

Chairman

A. J. C. Wilson Department of Physics, University of Birmingham, P.O. Box 363, Birmingham B15 2TT, England

Members

Th. Hahn (B.R.D.)

J. Trotter (Canada)

R. A. Young (U.S.A.)

COMMISSION ON CRYSTALLOGRAPHIC STUDIES AT CONTROLLED PRESSURES AND TEMPERATURES

\section{Chairman}

S. Block

Chief, Crystallography Section, National Bureau of Standards, Room A221, Materials Building, Washington D.C. 20234, U.S.A.

Elected members

S. Akimoto (Japan)

J. C. Joubert (France)

S. S. Kabalkina (USSR)

C. T. Prewitt (U.S.A.)

K. F. Seifert (B.R.D.)

J. P. Traverse (France)

Ex officio members

R. Rudman (U.S.A.) (as Chairman of the Commission on Crystallographic Apparatus)

K. Molière (B.R.D.) (as Chairman of the Commission on Electron Diffraction)

A. F. Andresen (Norway) (as Chairman of the Commission on Neutron Diffraction)
COMMISSION ON CRYSTALLOGRAPHIC

TEACHING

Chairman

C. A. Taylor

Department of Physics, University College, P. O. Box 78, Cardiff CF1 1XL, Wales

Elected members

A. Authier (France) (Secretary)

S. Caticha-Ellis (Brazil)

K. F. Fischer (B.R.D.)

M. Font-Altaba (Spain)

P. Krishna (India)

M. Laing (South Africa)

T. I. Malinovsky (USSR)

W. M. Meier (Switzerland)

G. Rigault (Italy)

COMMISSION ON ELECTRON DIFFRACTION Chairman

K. Molière (B.R.D.)

Max-Planck-Gesellschaft zur

Förderung der Wissenschaften, Fritz-Haber-Institut,

Faradayweg 4-6,

1 Berlin 33-Dahlem, B.R.D.

Elected members

P. Goodman (Australia)

K. W. Hedberg (U.S.A.)

K. Kuchitsu (Japan)

J. B. Pendry (U.K.)

H. M. Seip (Norway)

S. A. Semiletov (USSR)

G. A. Somorjai (U.S.A.)

D. Watanabe (Japan)

M. J. Whelan (U.K.)

COMMISSION ON NEUTRON DIFFRACTION Chairman

A. F. Andresen

Institutt for Atomenergi, P.O. Box 40, 2007 Kjeller, Norway

Elected members

G. Caglioti (Italy)

P. Coppens (U.S.A.)

D. $\operatorname{Cox}$ (U.S.A.)

S. Hoshino (Japan)

B. Klar (France)

W. C. Koehler (U.S.A.)

T. M. Sabine (Australia)

B. T. M. Willis (U.K.)

I. I. Yamzin (USSR) 


\section{Representatives on Bodies not belonging to the Union}

COMMTSSION ON THE SOLID STATE OF THE INTERNATIONAL. UNION OF PURE AND APPLIED PHYSICS

J. M. Cowley

Department of Physics,

Arizona State University,

Tempe, Arizona 85281, U.S.A.

INTERNATIONAL ORGANIZATION FOR CRYSTAL GROWTH

Representatives

A. Authier

Laboratoire de Minéralogie-

Cristallographie, Université de

Paris VI, Tour 16,4 place Jussieu, 75230 Paris Cedex 05, France

N. Kato

Department of Applied Physics,

Nagoya University, Faculty of

Engineering, Furo-cho, Chikusa-ku, Nagoya, Japan

\section{Alternate}

R. A. Laudise

Bell Laboratories, 600 Mountain Avenue, Murray Hill, New Jersey 07974, U.S.A.

ICSU ABSTRACTING BOARD

\section{Representative}

J. Trotter (Canada) (ex officio as Chairman of the Commission on Structure Reports)
Alternates

A. J. C. Wilson (U.K.) (ex officio as Chairman of the Commission on Journals)

R. A. Young (U.S.A.) (ex officio as Co-Chairman of the Commission on Journals)

ICSU COMMITTEE ON DATA FOR SCIENCE AND TECHNOLOGY (CODATA)

\section{Representative}

D. G. Watson (U.K.) (ex officio as Chairman of the Commission on Crystallographic Data)

CODATA TASK GROUP ON SOLUBILITY DATA

\section{Representative}

R. A. Laudise Bell Laboratories, 600 Mountain Avenue, Murray Hill, New Jersey 07974, U.S.A.

ICSU COMMTTTEE ON THE TEACHING OF SCIENCE

\section{Representative}

C. A. Taylor (U.K.) (ex officio as Chairman of the Commission on Crystallographic Teaching)

\section{Alternate}

A. Authier (France) (ex officio as Secretary of the Commission on Crystallographic Teaching)
CONFERENCE COMMTTTEE OF THE EUROPEAN PHYSICAL SOCIETY

Representative
A. Línek
Institute of Solid State Physics, Ceskoslovenská Akademie Věd, Cukrovarnická 10, Praha 6, Czechoslovakia

ICSU COMMITTEE ON SPACE RESEARCH (COSPAR) ad hoc GROUP ON MATERIALS SCIENCES IN SPACE

Representative

E. Kaldis

Laboratorium für

Festkörperphysik, ETH-Aussen-

station Hönggerberg,

Eidgenössische Technische

Hochschule, 8006 Zürich, Switzerland

ICSU COORDINATING COMMTTTEE FOR THE MOON AND PLANETS

Representative

M. Ross (as from 9 March 1976) United States Department of the Interior, Geological Survey, 959 National Center,Reston, Virginia 22092, U.S.A.

\section{Alternate}

J. J. Papike (as from 9 March 1976) Division of Natural Sciences, Applied Sciences Building, University of California, Santa Cruz, California 95064, U.S.A. 


\section{ANNEX IV Adhering Bodies}

\begin{tabular}{|c|c|c|}
\hline Country & Category* & Adhering Body \\
\hline Argentina & I & $\begin{array}{l}\text { Consejo Nacional de Investiga- } \\
\text { ciones Cientificas y Técnicas }\end{array}$ \\
\hline Australia & III & Australian Academy of Science \\
\hline Austria & I & $\begin{array}{l}\text { Österreichische Akademie der } \\
\text { Wissenschaften }\end{array}$ \\
\hline Belgium & II & $\begin{array}{l}\text { Académie Royale des Sciences, } \\
\text { des Lettres et des Beaux-Arts } \\
\text { de Belgique }\end{array}$ \\
\hline Brazil & I & $\begin{array}{l}\text { Conselho Nacional de } \\
\text { Pesquisas }\end{array}$ \\
\hline $\begin{array}{l}\text { B.R.D. } \\
\text { (Federal Republic } \\
\text { of Germany) }\end{array}$ & IV & $\begin{array}{l}\text { Arbeitsgemeinschaft Kristallo- } \\
\text { graphie }\end{array}$ \\
\hline Canada & III & National Research Council \\
\hline Chile & I & $\begin{array}{l}\text { National Committee for Crys- } \\
\text { tallography }\end{array}$ \\
\hline Czechoslovakia & I & Ceskoslovenská Akademie Věd \\
\hline $\begin{array}{l}\text { D.D.R. } \\
\text { (German Demo- } \\
\text { cratic Republic) }\end{array}$ & II & $\begin{array}{l}\text { Vereinigung für Kristallographie } \\
\text { in der G.G.W. der D.D.R. }\end{array}$ \\
\hline Denmark & I & $\begin{array}{l}\text { Akademiet for de Tekniske } \\
\text { Videnskaber }\end{array}$ \\
\hline Finland & I & Suomalainen Tiedeakatemia \\
\hline France & IV & $\begin{array}{l}\text { Académie des Sciences (Institut } \\
\text { de France) }\end{array}$ \\
\hline Hungary & I & $\begin{array}{l}\text { Magyar Tudományos } \\
\text { Akadémia }\end{array}$ \\
\hline India & I & $\begin{array}{l}\text { Indian National Science } \\
\text { Academy }\end{array}$ \\
\hline Israel & $\mathbf{I}$ & $\begin{array}{l}\text { Israel Academy of Sciences and } \\
\text { Humanities }\end{array}$ \\
\hline Italy & III & $\begin{array}{l}\text { Consiglio Nazionale delle } \\
\text { Ricerche }\end{array}$ \\
\hline Japan & IV & Science Council of Japan \\
\hline Netherlands & III & $\begin{array}{l}\text { Stichting voor Fundamenteel } \\
\text { Onderzoek der Materie met } \\
\text { Röntgen- en Elektronenstra- } \\
\text { len }\end{array}$ \\
\hline New Zealand & I & $\begin{array}{l}\text { The Royal Society of New } \\
\text { Zealand }\end{array}$ \\
\hline Norway & I & $\begin{array}{l}\text { Det Norske Videnskaps- } \\
\text { Akademi }\end{array}$ \\
\hline Poland & I & Polskiej Akademii Nauk \\
\hline
\end{tabular}

South Africa I South African Council for Scientific and Industrial Research

Spain

Sweden
III Consejo Superior de Investiga-
ciones Científicas

II Kungliga Vetenskapsakademien

\section{Secretary of National Committee}

M. Ipohorski, Departamento de Metalurgia, Comîsión Nacional de Energia Atómica, Avenida del Libertador 8250, Buenos Aires

The Executive Secretary, Australian Academy of Science, P.O. Box 783, Canberra City, A.C.T. 2601

A. Preisinger, Institut für Mineralogie und Kristallographie der Universität Wien, Dr-Karl-Lueger-Ring 1, A1010 Vienna

G. JACOBS, Rijksuniversiteit te Gent, Faculteit der Wetenschappen, Laboratorium voor Kristalkunde, Krijgslaan 271, B-9000 Gent

R. Rodrigues da Silva, Avenida Beira Mar, 2363 (Peidade), 50000 Recife

H. WONDRATSCHEK, Institut für Kristallographie der Universität, Kaiserstrasse 12,75 D-Karlsruhe 1

A. W. Hansen, Division of Biological Sciences, National Research Council of Canada, Ottawa, Ontario K1A 0R6

I. Garaycochea-Wittke, Departamento de Física, Universidad de Chile, Casilla 5487, Santiago

A. LfNek, Institute of Solid State Physics, Ceskoslovenská Akademie Věd, Cukrovarnická 10, Prague 6

H. Perbst, Zentralinstitut für Elektronenphysik, Deutsche Akademie der Wissenschaften der D.D.R., Mohrenstrasse 40/41, DDR-108 Berlin

I. KJøller Larsen, The Royal Danish School of Pharmacy, Chemical Laboratory C, Universitetsparken 2, 2100 Copenhagen $\varnothing$

P. PaAlassalo, Wihuri Physical Laboratory, University of Turku, 20500 Turku 50

J. F. Petroff, Association Française de Cristallographie, 4 place Jussieu, Tour 26, 75230 Paris Cedex 05

L. Zsoldos, Institute of Solid State Physics, Eötvös University, Müzeum krt. 6-8, 1088 Budapest

R. Chimambaram, Nuclear Physics Section, Bhabha Atomic Research Centre, Trombay, Bombay 400085

Michal Harel, The Weizmann Institute of Science, Rehovot

M. MaMmI, Istituto di Chimica Organica, Università di Padova, Via Marzolo 1, 35100 Padova

Y. SaIto, The Institute for Solid State Physics, University of Tokyo, Roppongi 7, Minato-ku, Tokyo 106

The Executive Secretary, FOMRE, Laan van Meerdervoort $53 \mathrm{~d}$, 's-Gravenhage

W. T. Robinson, Chemistry Department, University of Canterbury, Private Bag, Christchurch

Chr. Røмming, Department of Chemistry, University of Oslo, P.O. Box 1033, Blindern, Oslo 3

A. Pietraszko, Instytut Niskich Temperatur i Badań Strukturalnych, Polskiej Akademii Nauk, Plac Katedralny 1, 50-950 Wrocław

J. Coetzer, National Physical Research Laboratory, P.O. Box 395, Pretoria

S. García-Blanco, Instituto de Química Física 'Rocasolano', Consejo Superior de Investigaciones Científicas, Serrano 119, Madrid 6

S. Arrahamsson, Department of Structural Chemistry, University of Göteborg, Medicinareg. 9, S-400 33 Göteborg 33 


$\begin{array}{lcc}\begin{array}{l}\text { Country } \\ \text { Switzerland }\end{array} & \begin{array}{c}\text { Category* } \\ \text { II }\end{array} & \begin{array}{c}\text { Adhering Body } \\ \text { Schweizerische Gesellschaft für } \\ \text { Kristallographie }\end{array} \\ \begin{array}{l}\text { U.K. } \\ \text { U.S.A. }\end{array} & \text { V } & \begin{array}{c}\text { The Royal Society } \\ \text { USSR }\end{array} \\ \begin{array}{l}\text { Vugoslavia } \\ \text { Y }\end{array} & \text { I } & \begin{array}{c}\text { National Academy of Sciences } \\ \text { - National Research Council } \\ \text { Akademija Nauk S.S.S.R. }\end{array} \\ & & \begin{array}{c}\text { Jugoslavenska Akademija } \\ \text { Znanosti i Umjetnosti }\end{array}\end{array}$

Secretary of National Committee

W. H. MeIER, Institut für Kristallographie und Petrographie, Sonneggstrasse 5, CH-8006 Zürich

Sir David Martin, The Royal Society, 6 Carlton House Terrace, London SW1Y 5AG

W. R. BusING, Oak Ridge National Laboratory, P.O. Box X, Oak Ridge, Tennessee 37830, U.S.A.

V. I. Simonov, Institute of Crystallography, Leninsky prospekt 59, Moscow B-333

B. KamenaR, Laboratory of General and Inorganic Chemistry, Faculty of Science, Ulica Soc. Revolucije 8, 41000 Zagreb

* Adhence to the Union is in one of five Categories I-V, with corresponding voting powers and contributions as set out in Statutes $3 \cdot 6,5 \cdot 5$ and 9.4 .

\section{National Committees for Crystallography}

\section{Argentina}

S. Baggio (Chairman), María E. J. de Abeledo, L. N. Becka, Dora Bedlivy, M. A. R. de Benyacar, A. Bonfiglioli, M. Butschowski, E. E. Gallon, M. IPohorski, A. PODJARNY.

\section{Australia}

T. M. Sabine (Chairman), H. C. Freeman, E. O. Hall, C. H. L. Kennard, E. N. Maslen, A. F. Moodie, E. W. Radoslovich, R. L. Segall.

\section{Austria}

A. Preisinger (Chairman), H, Heritsch, O, Kratky, H. Nowotny, E. H. K. SCHMID, J. ZEMANN.

\section{Belgium}

W. Dekeyser (Chairman), H. Brasseur (Vice-Chairman), S. AmelinckX, L. Danguy, O. Goche, L. Habraken, G. Homes, G. Jacobs, J. Moreau, P. Piret, J. Toussaint, M. Van Meerssche, R. Van Tassel.

\section{Brazil}

S. Caticha-Ellis, Y. P. Mascarenhas, R. Rodrigues da Sllva, E. TÁvora, J. V. Valarelli.

\section{B.R.D. (German Federal Republic)}

H. Wondratschek (Chairman), K. Bonse, W. HoffMANN, F. Liebau, K. Molière, H. G. von Schnering, H. Schulz.

\section{Canada}

I. D. Brown (Chairman), G. Donnay, F. Einstein, A. W. Hanson, E. Stanley.

\section{Chile}

O. Wittke (Chairman), Isabel Garaycochea-WittKe.

\section{Czechoslovakia}

A. Kochanovská (Chairman), J. Garaj (Vice-Chairman), C. Barta, F. Сech, M. CernohorskÝ, M. Dunaj-Jurčo, S. Ďurovič, M. Handlovič, K. Huml, J. Komrska, A. ĹfNeK, J. MAĎAR, K. MELKa, L. UlickÝ.

\section{D.D.R. (German Democratic Republic)}

H. Neels (Chairman), O. Brümmer, A. Feltz, J. HeYdenreich, E. Höhne, P. Paufler, H. Peibst, M. Schenk.

\section{Denmark}

K. Drenck (Chairman), E. K. Andersen, J. Danielsen, O. Dietrich, B. Jerslev, I. KJøller Larsen, A. LindegaARd Andersen, H. Micheelsen, H. Pauly, J. VilLADSEN, K. WATSON.

\section{Finland}

V. Hovi (Chairman), P. Kettunen, K. Kurki-Suonio, P. Paalassalo, A. Pajunen, Th. Sahama, E. Suoninen.

\section{France}

R. Kern (Chairman), A. Authier and H. Brasseur (ViceChairmen), G. Allais, M. Alleaume, R. Comès, Y. Jeannin, J. Lajzerowicz, C. Pascard, J. F. Petroff.

\section{Hungary}

K. SASVÁRI (Chairman), M. Farkas-Jahnke, I. HaRgittai, A. Kálmán, E. Krén, L. Malicskó, K. Simon, K. SztróKAI, I. TARJÁN, L. ZSOLdOS.

\section{India}

S. Ramaseshan (Chairman), R. Chidambaram, B. G. GoKhale, M. P. Gupta, Krishan lal, P. Krishna, A. R. Patel, A. Sequeira, R. Srinivasan.

\section{Israel}

L. Leiserowitz (Chairman), J. Bernstein, Z. Dori, Michal Harel, J. Perl.

Italy

A. Vaciago (Chairman), G. Allegra, G. Caglioti, E. Cannillo, A. Coda, M. Mammi, M. Nardelli, G. Rigault, S. QUARENI.

\section{Japan}

S. TAKaGi (Chairman), H. Hashimoto, S. Hoshino, S. Hosoya, Y. IItaka, M. Kakudo, N. Kato, K, KoHra, K. Kuchitsu, F. Marumo, N. Morimoto, Y. Saito, T. Sakurai, I. Sunagawa, I. Tanaka, D. Watanabe.

\section{Netherlands}

D. Feil (Chairman), P. T. Beurskens, P. B. Braun, J. Drenth, Th. J. H. Geurtz, P. Hartman, A. A. Holscher, B. O. Loopstra, M. G. Nordholt, B. Okkerse, A. F. Peerdeman, G. D. Rieck, H. M. Rietveld, C. Romers, J. W. Visser, C. G. Vonk, A. Vos, P. M. DE WolfF. 
New Zealand

P. P. Williams (Chairman), E. N. Baker, D. S. Coombs, A. G. Freeman, B. R. Penfold, W. T. Robinson, S. V. Rumball, J. M. Waters, T. N. Waters.

\section{Norway}

S. Furberg (Chairman), O. Foss, J. GJøNNES, F, GrøNvold, Chr. Rømming, H. M. SeIP, H. Sørum.

\section{Poland}

K. LuKaszewicz (Chairman), J. Auleytner (Vice-Chairman), Z. Bojarski, J. Leciejewicz, A. Pietraszko, W. TrZEBIATOWSKI, J. ZMiJA.

\section{South Africa}

G. Gafner (Chairman), J. Coetzer, M. J. LAING.

\section{Spain}

L. Brứ (Chairman), J. Doetsch, M. Font-Altaba, S. García-Blanco, A. Hoyos, J. Rodríguez.

\section{Sweden}

A. MaGnÉlr (Chairman), S. Abrahamsson, B. Aurivillius, O. Beckman, D. Carlström, G. HägG, N. Ingri, G. Johansson, P. KierkegaArd, B. LindqVist, I. LindQVist, G. Lundgren, S. Lundevist, I. Olovsson.

\section{Switzerland}

A. Niggli (Chairman), E. Kaldis (Vice-Chairman), P. Engel, F. Laves, W. M. Meier, W. Nowacki.

$$
U . K \text {. }
$$

A. J. C. Wilson (Chairman), D. M. Blow, W. Cochran, D. W. J. Cruickshank, K. Dunham, M. Hart, D. C. Hodgkin, H. Massey, P. G. Owston, G. V. Raynor, C. A. TAYlor, H. F. W. TAYlor, D. G. WATSON, M. M. WOOLFSON.

$$
\text { U.S.A. }
$$

M. H. Mueller (Chairman), D. H. Templeton (ViceChairman), S. C. Abrahams, R. F. Bryan, R. D. Burbank, W. R. Busing, C. N. Caughlan, J. M. Cowley, J. P. Glusker, J. A. Ibers, G. A. Jeffrey, C. K. Johnson, I. L. Karle, W. L. Kehl, E. C. Lingafelter, R. E. Newnham, H. M. Ondik, D. P. Shoemaker, D. K. Smith, R. A. Young.

\section{USSR}

N. V. Belov (Chairman), G. B. BoKy, A. I. KitaigorodSky, Z. G. Pinsker, M. M. Umansky, I. I. Shafranovsky, N. N. Sheftal, V. I. Simonov, B. K. Vainshtein, G. S. ZHDANOV.

\section{Yugoslavia}

D. Grdenić (Chairman), A. BezJak, L. Golič, R. Herak, B. Kamenar, K. Kranic, I. Krstanović, B. Matković, V. Marinković, B. Ribár, S. ŠćavniČar.

\section{International Union of Crystallography}

\section{World Directory of Crystallographers Fifth Edition}

Biographical data for the Fifth Edition of the World Directory of Crystallographers are now being compiled in many countries. Each crystallographer in the countries listed below should have received a Data Input Form for him to complete from his national Sub-Editor: any crystallographer who has not received a Data Input Form should request one from his Sub-Editor. Efforts are being made to contact crystallographers in all other countries: if not reached by 1 August 1976, they should write directly to the General Editor, Dr S. C. Abrahams, Bell Laboratories, Murray Hill, New Jersey 07974, U.S.A. Scientists with crystallographic colleagues in countries without Sub-Editors are requested to bring this notice to their attention.

The Fifth Edition of the World Directory of Crystallographers will be produced by computer-controlled photocomposition from punched cards prepared by the SubEditors. The resulting book is expected to be published by mid-1977, and to compare favourably with the Fourth Edition in appearance but at a substantially lower cost.

\section{Sub-Editors}

Argentina

Dr M. J. de Abeledo, Comisión Nacional de Energía Atómica, Urquiza 254, Acassuso, Buenos Aires
Australia

Dr W. A. Denne, C.S.I.R.O., Division of Chemical Physics, P.O. Box 160, Clayton, Victoria 3168

Austria

Prof. Dr A. Preisinger, Institut für Mineralogie und Kristallographie, Universität Wien, Dr.-Karl-Lueger-Ring 1, A-1010 Wien

Bangladesh

Prof. Kh. A. I. F. M. Mannan, Physics Department, University of Dacca, Dacca 2

Belgium

Prof. Dr G. Jacobs, Rijksuniversiteit te Gent, Faculteit der Wetenschappen, Laboratorium voor Kristalkunde, Krijslaan 271, B-9000 Gent

Bolivia

Lic. Luis A. Guzmán, Instituto de Investigaciones Físicas, Universidad Mayor de San Andrés, La Paz

Brazil

Dr Yvonne Mascarenhas, Universidade de São Paulo, 'Campus' de São Carlos, Caixa Postel 369, C E P 13.560, São Carlos (SP)

Bulgaria

Prof. I. Kostov, Chair of Mineralogy and Crystallography, University of Sofia, Boulevard Russki 15, Sofia Burma

Mr Saw Tun, Research Officer, Central Research Organisation, Yankin P.O., Rangoon

Canada

Dr A. W. Hanson, Division of Biological Sciences, National Research Council of Canada, Ottawa, K1A 0R6 